\title{
A KÉT-FOTONOS POLIMERIZÁCIÓ ÉS A HOLOGRAFIKUS OPTIKAI CSIPESZ ALKALMAZÁSÁNAK ÉS TECHNIKÁJÁNAK KÖLCSÖNÖS KITERJESZTÉSE
}

\author{
Ph.D. értekezés
}

\section{VIZSNYICZAI GASZTON}

TÉMAVEZETÕ :

Dr. Kelemen Lóránd

MTA Szegedi Biológiai Kutatóközpont, Biofizikai Intézet

Fizika Doktori Iskola

Szegedi Tudományegyetem

Természettudományi és Informatikai Kar

Szeged, 2019 


\section{TARTALOMJEGYZÉK}

1. Bevezetés 3

2. Tudományos háttér 6

2.1. Két-fotonos polimerizáció . . . . . . . . . . . . . . 6

2.1.1. Két-fotonos abszorpció . . . . . . . . . . . . . . . 7

2.1.2. TPP gyakorlati megvalósítása . . . . . . . . . . . . . 9

2.1.3. SU-8 fotopolimer . . . . . . . . . . . . . . . . . 11

2.2. Optikai csipesz . . . . . . . . . . . . . . . . . . . 12

2.2.1. Bevezetés . . . . . . . . . . . . . . . . 12

2.2.2. Holografikus optikai csipesz . . . . . . . . . . . . . 15

2.3. Holografikus lézernyaláb formázás . . . . . . . . . . . . . . . . . 16

2.3.1. LCOS Térbeli fázismodulátorok . . . . . . . . . . . . . . . 18

2.3.2. Több fókuszpont holografikus előállítása . . . . . . . . . . . . . 19

3. Eredmények 22

3.1. Holografikus két-fotonos polimerizáció . . . . . . . . . . . . . . . . 22

3.1.1. Bevezetés . . . . . . . . . . . . . . . . 22

3.1.2. Kísérleti elrendezés . . . . . . . . . . . . . . . . . . . . 23

3.1.3. A holografikus TPP folyamata . . . . . . . . . . . . . . 24

3.1.4. Eredmények . . . . . . . . . . . . . . . . 25

3.1.5. Konklúzió . . . . . . . . . . . . . . . . . . . . . . 27

3.2. Biológiai sejtek indirekt optikai manipuláción alapuló többnézetú mikroszkópiája . . . . . . . . . . . . . . . . . . . . 29

3.2.1. Mikrostruktúra alapú indirekt optikai manipuláció . . . . . . . . . 29

3.2.2. Fluoreszcens mikroszkópra épített Holografikus Optikai Csipesz . 34

3.2.3. Multiview mikroszkópia . . . . . . . . . . . . . . . . . 38

3.2.4. Konklúzió . . . . . . . . . . . . . . . . . . . . . 45

Köszönetnyilvánítás $\quad 46$

Összefoglalás $\quad 47$ 
Summary

Publikációs lista

IRODALOMJEGYZÉK

53 


\section{BEVEZETÉS}

Tudományos munkám során két lézer alapú technika, illetve vizsgálati módszer gyakorlati megvalósításával, fejlesztésével és kísérletes felhasználásával foglalkozom. E két módszer a két-fotonos polimerizáció, mint lézeres mikrofabrikációs eljárás, és az ún. holografikus optikai csipesz, mint lézeres mikromanipulációs vizsgálati módszer.

A két-fotonos polimerizáció a jelenleg legnagyobb felbontással rendelkezô háromdimenziós fotolitográfiás módszer. Az 1997-ben bemutatott [1] módszerrel tetszóleges alakú, szub-mikrométeres részletességú mikrostruktúrák készíthetőek fényre megszilárduló, ún. fotopolimer anyagokból. Napjainkra a módszer széles körben elterjedt mikrostruktúrák készítésére, többek között mikromechanikai, integrált-optikai és biológiai alkalmazásokra. Hamar sor került olyan mikrostruktúrák bemutatására is, amelyek fénynyalábokkal, az úgynevezett lézercsipesz optikai mikromanipulációs technikájával múködtethetôk $[2,3]$.

A lézeres optikai csipesz, az elektromágneses sugárzás impulzusából eredő erőket kihasználva, lehetôvé teszi mikrométeres részecskék térbeli manipulálását, "csipeszelését" fókuszált lézernyalábokkal. A lézercsipesz tipikusan egy mikroszkóp objektív által vizes közegbe fókuszált nagy numerikus apertúrájú lézernyalábon alapul, amely fókuszában a víznél nagyobb törésmutatójú, nem abszorbeáló, dielektrikum mikro-objektumok csapdázhatóak. A csipeszelt objektumok, amelyek lehetnek mind szintetikus (pl. mikrogolyók), mind biológiai jellegúek (pl. sejtek, sejtalkotók), a csapdázó fókusz mozgatásával három-dimenzióban manipulálhatóak, valamint megfelelő kalibrációkkal a rájuk ható külső erôk is megmérhetőek. Az optikai csipesz olyan új biofizikai kísérleteket tett lehetővé, mint például biológiai motor fehérjék nanométeres mozgásának [4], vagy erókifejtésének [5] megmérése, valamint DNS molekulák elasztikus tulajdonságainak meghatározása [6].

A lézercsipesz alkalmazásának spektruma jelentősen kiterjeszthető olyan technikákkal, amelyekkel a csapdázó lézer több fókuszpontba irányítható, így megtöbbszörözve az optikai csapdák számát. Erre a legelterjedtebb, legsokoldalúbb módszer az ún. holografikus optikai csipesz [7,8], amely a csapdázó lézernyaláb holografikus formázásán alapul. Ennek alapja egy olyan számítógéprôl vezérelhetô diffraktív optikai elem, úgynevezett térbeli fázismodulátor (Spatial Light Modulator, SLM), amellyel egy lézernyaláb hullámfrontja nagy felbontással alakítható egy számítógépes hologram formájára. A holografikus optikai csipesszel létrehozható nagy számú, három-dimenzióban függetlenül mozgatható optikai csapdával lehetséges kiterjedt mikro-objektumok több ponton történó megfogása, 
vagy például élố sejtek precíz három-dimenziós elrendezése [9].

A két-fotonos polimerizációval megmunkált fotopolimer anyagok többsége a lézercsipesszel való csapdázáshoz ideális optikai tulajdonságokkal rendelkezik. Ennek fényében több kutatócsoport is elkezdett olyan két-fotonos polimerizációval előállított mikrostruktúrák fejlesztésével foglalkozni, amelyek lézercsipesszel múködtethetőek, illetve új fajta kísérletek elvégzésére teszik alkalmassá az optikai csapdázást. E területen az elsôk között kezdett el alkotni Ormos Pál Professzor kutatócsoportja a Szegedi Biológiai Kutatóközpont Biofizikai Intézetében. A csoport Dr. Kelemen Lóránd által vezetett két-fotonos polimerizációs laborjában kezdetben fénnyel hajtott mikromotorok [10,11], valamint Prof. Jesper Glückstad (Technical University of Denmark) dániai kutatócsoportjával együttmúködve optikai mikromanipulációval összeilleszthető "építőkocka" mikrostruktúrák készültek $[12,13]$.

A kutatócsoport munkájába 2008-ban kapcsolódtam be mint szakdolgozó diák. Diplomamunkám keretében egy görbült felületû térbeli fázismodulátor optikai torzító hatását mértem ki egy Michelson interferométer megépítésével és a rögzített interferogramok számítógépes feldolgozásával. A torzulás ismeretében lehetségessé vált annak kompenzációja az SLM-et vezérlő hologramokba kódolva. Az így megjavított SLM-et ezután sikeresen tudtuk alkalmazni a csoport két-fotonos polimerizációs rendszerében a polimerizáló lézer több fókuszpontba irányítására, és így a mikrostruktúra gyártás felgyorsítására [14].

Az egyetemi diplomám megszerzése (2010) után PhD hallgatóként folytattam munkámat a kutatócsoportban. Ennek keretében elsóként a hidrodinamikai szinkronizáció jelenségének vizsgálatában vettem részt, amely magába foglalt optikailag csapdázott mikrostruktúrákon alapuló kísérleteket, valamint numerikus modellezést is [15]. Ezt követően közremúködtem olyan, holografikus optikai csipesszel alkalmazható, két-fotonos polimerizációval készülô mikrostruktúrák fejlesztésében amelyek új alkalmazásokra terjesztik ki az optikai csapdázás módszerét [16-18].

Önálló projektemként vizsgáltam a holografikus lézercsipesz alapját adó, dinamikus holografikus lézernyaláb formázás alkalmazhatóságát a két-fotonos polimerizációban. Sikeresen megvalósítottam a két-fotonos polimerizáció egy olyan új módját, ahol egyes mikrostruktúrák párhuzamosan több holografikusan létrehozott és mozgatott fókuszpont által exponálódnak [19].

Mindezek mellett nagymértékben hozzájárultam még egy további kutatási projekt végrehajtásához, amelynek keretében biológiai sejtek mikrostruktúra alapú indirekt optikai manipulációját valósítottuk meg. Habár sejtek optikai csapdázása és manipulációja közvetlen módon is kivitelezhetô, a lézercsipesz nagy intenzitású fókusza gyakran káros a sejtekre, valamint a sejtek optikai jellemzôi miatt a csapdázási erô is gyenge. Ezen problémák megoldását céloztuk meg olyan két-fotonos polimerizációval készülő mikrostruktúrákkal, amelyek holografikus lézercsipesszel nagy stabilitással 6 szabadsági fok mentén mozgathatóak. Ezen mikromanipulátor struktúrák biológiai sejtekhez tapasztha- 
tóak felületük biokémiai funkcionalizálása révén, aminek eljárását a csoportunk egykori PhD hallgatója, Badri L. Aekbote dolgozta ki [20]. Az ily módon megvalósított nagy precizitású, három-dimenziós indirekt sejt manipulációs módszert [21] ezután egyes sejtek többnézetú ("multiview") fluoreszcens mikroszkópiájára terveztük felhasználni. Ehhez szükségessé vált egy fluoreszcens mikroszkóppal egybeépített holografikus optikai csipesz rendszer. Ennek megtervezését és megépítését magam végeztem el, beleértve a holografikus lézercsipeszt és a mikroszkópos képalkotást szinkronban vezérlő szoftver megírását is. A megépített rendszerrel sikeresen tudtunk egyes sejtekról több orientációban rögzíteni három-dimenziós képsorozatokat, amelyeket számítógépes feldolgozással összekombinálva a megfigyelt sejt három-dimenziós szerkezetét izotrop felbontással tudtuk rekonstruálni.

Dolgozatomban ismertetem a két-fotonos polimerizáció, az optikai csipesz, és a holografikus lézernyaláb formázás alapjait. Eredményeim között először bemutatom a dinamikus holografikus lézernyalábokkal történő két-fotonos polimerizáció megvalósítását. Ezt követően bemutatom a biológiai sejtek indirekt optikai manipulációjának módszerét, továbbá annak alkalmazását egyes sejtek izotrop felbontású képalkotására, az úgynevezett multiview fluoreszcens mikroszkópia megvalósítása révén. 


\section{TUDOMÁNYOS HÁTTÉR}

\subsection{Két-fotonos polimerizáció}

A két-fotonos polimerizáció (TPP) egy lézeres mikrofabrikációs eljárás, amellyel komplex három-dimenziós struktúrák készíthetőek, akár a diffrakciós határnál is finomabb részletességgel. A módszer UV-fényre reagáló fotopolimer anyagok két-fotonos gerjesztés általi polimerizációján alapul, amit egy megfelelő hullámhosszú ( 800 nm) ultrarövid impulzus lézer nagy numerikus apertúrájú fókuszával valósítanak meg. Mivel a két-fotonos abszorpció egy négyzetes intenzitás-függésú nemlineáris folyamat, a fotopolimer polimerizációja az alkalmazott lézerfókuszon belül egy szúk térfogatra korlátozható. A lézerfókusz térbeli mozgatásával tetszóleges három-dimenziós mikrostruktúrák polimerizálhatóak, amelyekrôl a fabrikáció végén a nem polimerizálódott fotopolimer oldószerekkel eltávolítható. A TPP módszere megszületését az ultrarövid ( 100fs) impulzushosszú lézerek fejlődésének köszönheti, amelyek lehetôvé tették a két-fotonos abszorpció folyamatának gyakorlati hasznosítását. Röviddel az elsô két-fotonos gerjesztésen alapuló fluoreszcens pásztázó mikroszkóp [22] megalkotását követôen már demonstrálták a két-fotonos abszorpció alkalmasságát lézeres litográfia feloldásának javítására [23]. Pár évvel ezután Maruo és munkatársai bemutatták az első három-dimenziós mikrofabrikációra képes két-fotonos fotopolimerizációs rendszert [1].
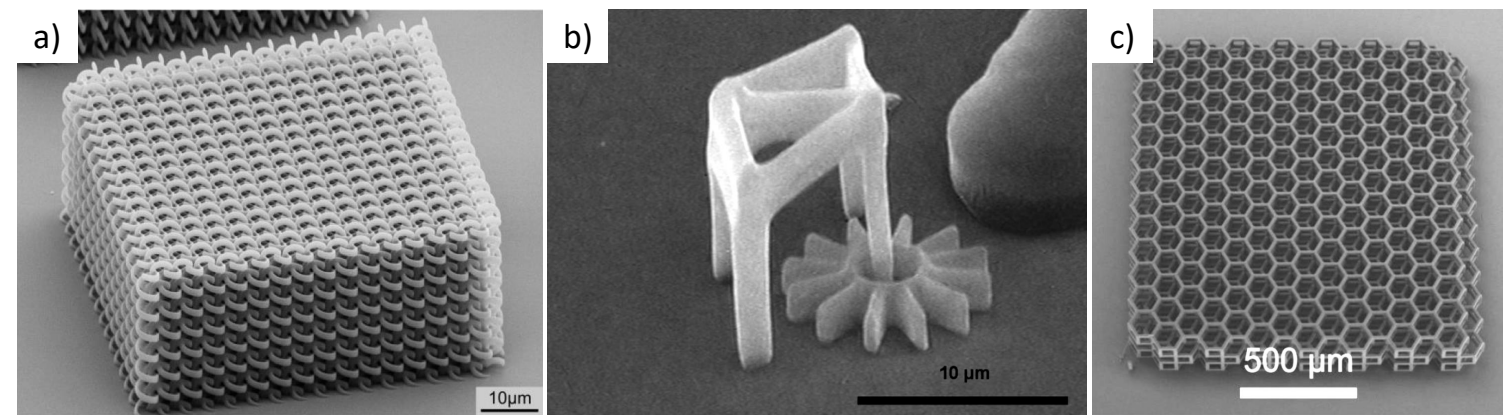

2.1. ábra. Példák két-fotonos polimerizációval készített mikrostruktúrákra. a) Infravörös fotonikus kristály [24]. b) Fénnyel hajtott mikromotor [11]. c) Mesterséges szövetváz ("tissue scaffold") sejtkultúra három-dimenziós növekedésének elôsegítéséhez [25].

Napjainkra a két-fotonos polimerizáció széles körben elterjedt módszer lett olyan funkcionális mikrostruktúrák (2.1 ábra) készítésére [26], mint például infravörös fotonikuskristályok [24,27,28], mikrofluidikai csatornák [29], fénnyel hajtott mikrogépek [2,11,30], 
vagy biokompatibilis anyagok három-dimenziós strukturálása [25,31,32].

\subsubsection{Két-fotonos abszorpció}

A két-fotonos abszorpció (TPA) egy harmadrendú nemlineáris optikai folyamat, amely során egy molekula két foton kvázi egyidejú elnyelése által kerül gerjesztett állapotba (2.2 ábra). A két foton lehet azonos, illetve különböző energiájú (hullámhosszú), a gyakorlatban azonban a TPP esetén azonos hullámhosszú fotonok játszanak szerepet. Az egy-fotonos abszorpcióval szemben a TPA során az egyes fotonok nem hordoznak elég energiát a kölcsönható molekula gerjesztett állapotának eléréshez, az elsô kölcsönható foton egy nagyon rövid életidejú $\left(10^{-15}-10^{-16} \mathrm{~s}\right)$ virtuális állapotba történô átmenetet okoz, a második gerjesztő fotonnak pedig ezen időablakon belül kell a molekulát eltalálnia a gerjesztett állapot eléréséhez.

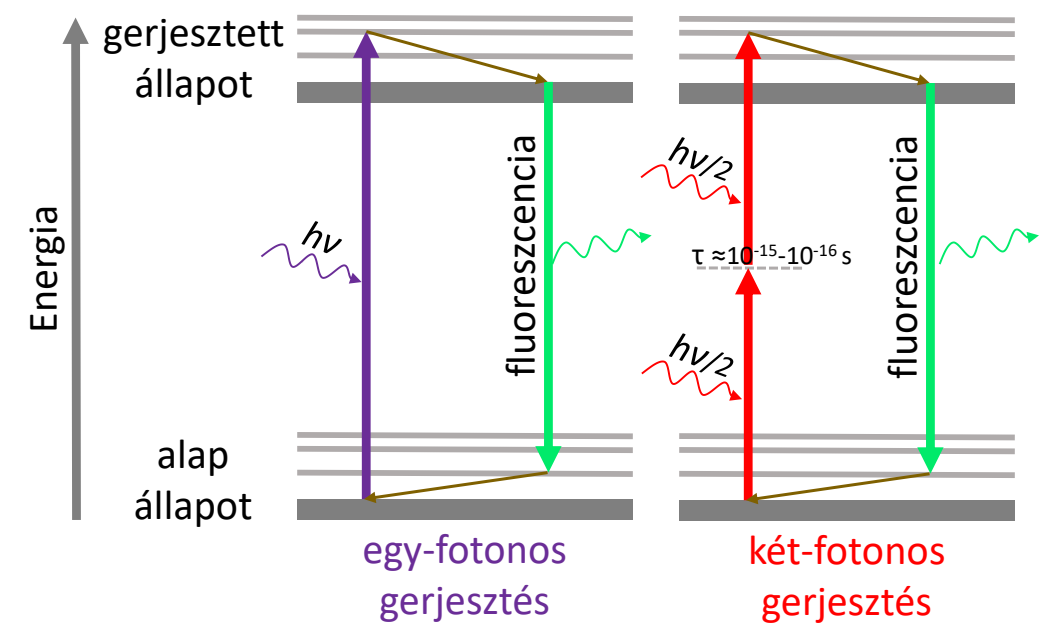

2.2. ábra. Egy- és két-fotonos fluoreszcencia gerjesztés Jablonski-diagramja.

Egy adott anyagban TPA révén egységnyi idő alatt egységnyi térfogatban elnyelt energia a következóképpen írható fel [33]:

$$
\frac{d W}{d t}=\frac{8 \pi^{2} \omega}{c^{2} n^{2}} I^{2} \operatorname{Im}\left(\chi^{(3)}\right)
$$

ahol $n$ a törésmutató, $\omega$ és $I$ a gerjesztő fény frekvenciája illetve intenzitása, $c$ a vákuumbeli fénysebesség, valamint $\operatorname{Im}\left(\chi^{(3)}\right)$ az elnyelô anyag harmadrendú elektromos szuszceptibilitásának képzetes része. A TPA valószínúsége hatáskeresztmetszettel jellemezhetô:

$$
\frac{d n_{p}}{d t}=\sigma_{2} N F^{2}
$$

ahol $d n_{p} / d t$ az egységnyi idő alatt elnyelt fotonok száma, $\sigma_{2}$ a két-fotonos abszorpciós hatáskeresztmetszet, $N$ az elnyelő molekulák egységnyi térfogatbeli száma, és $F$ a gerjesztô 
fény fluxusa, $F=I / h \nu$. A fenti egyenletek alapján:

$$
\sigma_{2}=\frac{8 \pi^{2} h \nu^{2}}{c^{2} n^{2} N} \operatorname{Im}\left(\chi^{(3)}\right)
$$

A két-fotonos abszorpciós hatáskeresztmetszet $\sigma_{2}$ tipikus nagyságrendje $10^{-48} \mathrm{~cm}^{4}$ s photon ${ }^{-1}$ [34]. A TPA gyakorlati megvalósításához rendkívül nagy optikai intenzitásokra van szükség $\left(10^{9} \mathrm{~W} / \mathrm{cm}^{2}\right)$, amit ultrarövid impulzushosszú ( 100 fs) lézerek lefókuszált nyalábjával a legkönnyebb előállítani.

a)

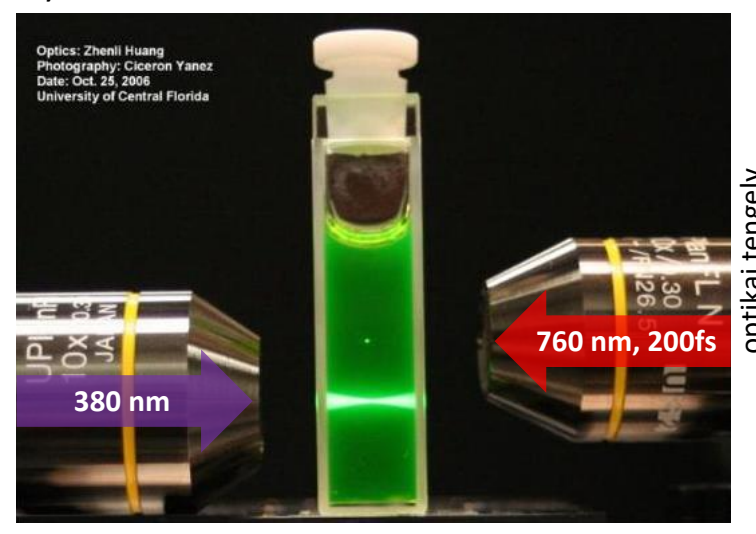

b)

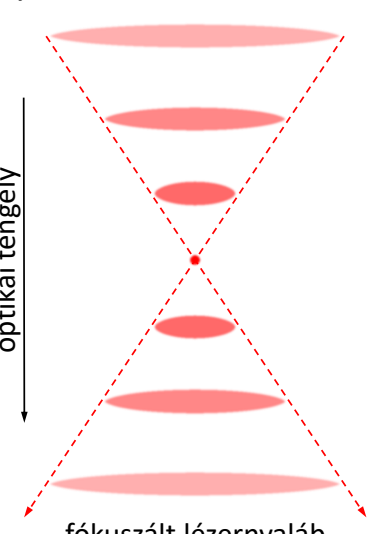

fókuszált lézernyaláb

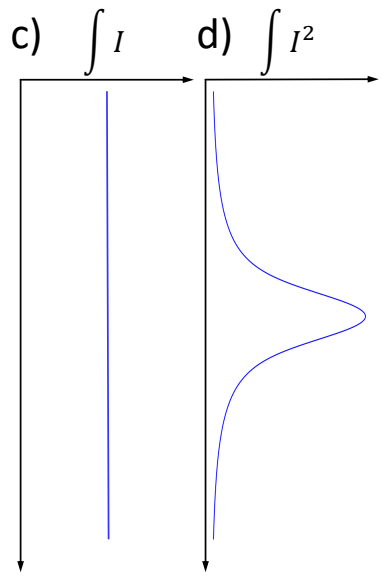

2.3. ábra. Egy- és két-fotonos gerjesztés lokalizálhatósága. a) Fluoreszcens minta gerjesztése fókuszált lézernyalábokkal. A balról érkezô egy-fotonosan gerjesztô 380 nanométeres lézernél a nyaláb teljes terjedelmében megfigyelhetô a minta fluoreszenciája. A jobbról érkezó infravörös femtoszekundumos impulzus lézer nyalábja csak a fókuszban gerjeszt fluoreszcenciát a TPA nemlineáris intenzitás-függése miatt. b) Fókuszált lézernyaláb keresztmetszeti síkjainak sematikus reprezentációja. c) Egyfotonos gerjesztés mértékének függése a nyalábátmérôtól. b) Két-fotonos gerjesztés mértékének függése a nyalábátmérôtól.

Egy minta fókuszált lézernyalábbal történô gerjesztése TPA alkalmazásával a nemlineáris intenzitásfüggés miatt jóval nagyobb mértékben lokalizálható mint egy-fotonos elnyelés esetén. Ezt könnyú belátni, ha megvizsgáljuk egy homogén fluoreszcens minta lézeres gerjesztését (2.3.a ábra). Egy-fotonos gerjesztés esetén a nyaláb bármely keresztmetszeti síkjában (2.3.b ábra) egységnyi idô alatt elnyelt energia állandó (gyengén elnyelô minta esetén), és lineárisan arányos a keresztmetszeti síkban integrált nyaláb intenzitással, azaz a nyaláb teljes teljesítményével (2.3.c ábra). Ezzel szemben két-fotonos gerjesztés esetén egy keresztmetszeti síkban elnyelt energia a nyaláb intenzitás négyzetének síkbeli integráljával arányos, amelynek nagysága a fókuszponttól távolodva gyorsan csökken (2.3.d ábra).

A TPA alkalmazásának további előnyei is vannak. A legtöbb fotopolimer anyag és fluoreszcensen jelölt biológiai minta nagy mértékben transzparens az egy-fotonos elnyelésük kétszeres hullámhosszán. Emiatt a két-fotonos gerjesztés kivitelezhetô vastag minták 
belsejében is mivel a gerjesztô lézer fotonjai nem nyelődnek el egy-fotonos abszorpcióval mielőtt elérnék a fókuszpontot. Biológiai minták két-fotonos mikroszkópiája esetén a fókuszponton kívüli fényelnyelés hiányában minimalizálható a jelölő festékek kifakítása (photobleaching) és a biológiai objektumok fény általi roncsolása (photodamage).

\subsubsection{TPP gyakorlati megvalósítása}

Egy két-fotonos polimerizációs rendszer legalább három fő komponensből épül fel: 1. femtoszekundumos impulzus lézer, 2. optikai rendszer a lézernyaláb megfelelő fókuszálásához, 3. három-dimenziós pozicionáló rendszer a fókuszpont térbeli mozgatásához.

Az alkalmazott impulzus lézerek általában 700 - 800 nm körüli hullámhosszúak, mivel a legtöbb kommerciális fotopolimer anyag a 350 - 400 nm hullámhossz tartományon érzékeny. A legelterjedtebben használt lézer típusok a Ti :sapphire lézerek és a frekvenciakétszerezett Erbium-szennyezett szállézerek (Erbium-doped fiber laser). Ezen lézerek tipikusan néhány száz mW átlagteljesítménnyel állítanak elô 100 fs hosszú impulzusokat $\sim 100 \mathrm{MHz}$ ismétlési frekvenciával.

A TPP legjobb felbontásának eléréséhez szükséges a polimerizáló lézernyaláb minél erôsebb lefókuszálása. Ezért a TPP rendszerek fô optikai eleme egy nagy numerikus apertúrájú mikroszkóp objektív, általában 60-100x közötti nagyítással és 1.2-1.4 közötti numerikus apertúrával. Az optikai rendszer további részei a lézernyaláb méretét és intenzitását kontrolláló elemek: nyalábtágító lencse párok, illetve a lézerteljesítményt állító polarizációs elemek vagy akuszto-optikai modulátorok.

A polimerizáló lézerfókusz térbeli mozgatására két különbözô megoldás a legelterjedtebb: piezoelektromos háromtengelyú lineáris aktuátorok, illetve galvo pásztázó egységek kombinálva egy egytengelyú piezo aktuátorral. A háromtengelyú piezo aktuátorok általában a fotopolimer mintát mozgatják a polimerizáló fókuszponthoz képest. Mozgási tartományuk tipikusan néhány száz mikrométer nagyságú, amelyen belül tetszóleges három-dimenziós útvonalakon képesek mozogni nanométeres pontossággal. Maximális sebességük $\sim 100 \mathrm{\mu m} \mathrm{s}^{-1}$. A galvo pásztázó mozgatás alapja egy elektronikusan dönthető tükörpár, amelynek elemei képesek a róluk visszavert lézernyaláb szögét 1-1 tengely mentén nagy frekvenciával változtatni. Az optikai rendszerbe megfelelő́n beépítve a galvo pásztázó képes a lézer fókuszát az objektív fókuszsíkján belül $\mathrm{mm} \mathrm{s}^{-1}$ nagyságrendú sebességgel mozgatni. A polimerizáló fókusszal ily módon elérhető területet az objektív látómezôjének mérete limitálja ( 100 x $100 \mu \mathrm{m}^{2}$ ). A galvo pásztázó TPP rendszerekben a mikrostruktúrák fabrikációja a fókuszsíkba esố rétegenként történik, egy adott réteg levilágítása után a fókuszsíkot egy piezo-eltoló a következő réteg helyére pozicionálja a fotopolimer mintán belül. A fentieken felül a TPP rendszereket gyakran felszerelik még egy nagyobb mértékú síkbeli mozgatást biztosító eszközzel, például léptetômotoros mikroszkóp asztallal. Ez lehetôvé teszi mikrostruktúrák készítését a fotopolimer minta kiterjedt területein. 


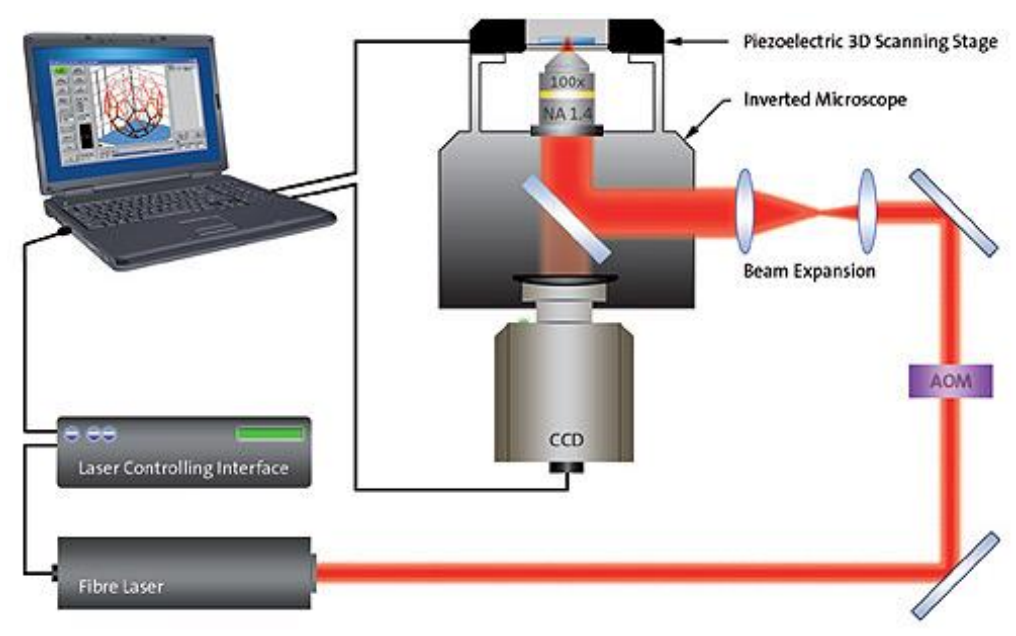

2.4. ábra. Két-fotonos polimerizációs rendszer sematikus felépítése [35].

A 2.4 ábrán látható egy tipikus két-fotonos polimerizációs rendszer felépítése. Egy femtoszekundumos szállézer kitágított nyalábját egy nagy numerikus apertúrájú olaj immerziós objektív (100x, 1.4 NA) fókuszálja egy 3D piezo eltolóra felfogatott fotopolimer mintába. A fókuszpontba jutó lézerteljesítmény egy akuszto-optikai modulátorral (AOM) állítható. A fókuszáló objektív és a piezo mozgató rendszer egy CCD kamerával felszerelt invertált mikroszkópra van építve. A mikroszkóp képalkotó rendszere lehetővé teszi a TPP folyamatának valósidejú monitorozását. A teljes rendszer számítógéprôl vezérelhető, a mikrofabrikációs folyamatot egy dedikált szoftver irányítja.

A fotopolimer anyagot általában egy mikroszkóp fedólemez hordozza, amelyen áthalad a lézer lefókuszált nyalábja. A fókusszal a fotopolimer egy pontjának exponálása egy forgási ellipszoid alakú térfogat, az ún. voxel polimerizációját eredményezi. A voxel mérete egy adott fotopolimer anyagban elsősorban a lézerteljesítmény és az expozíciós idô változtatásával szabályozható, amelyektól való függése matematikai modellekkel jól leírható [37].

Egy mikrostruktúra készítése során a fókusz adott lézerteljesítmény és pásztázási sebesség mellett megtervezett útvonalak mentén mozogva exponálja a struktúra egyes részeit, úgy, hogy a pásztázó megvilágítás végén a fotopolimer a mikrostruktúra tervezett alakját közelítő térfogatban polimerizálódik. Ezt a folyamatot egy három-dimenziós piezoaktuátorral pásztázó TPP rendszerre a 2.5 ábra szemlélteti.

A mikrofabrikáció végén szükséges még a mikrostruktúrákat körülvevố nem polimerizálódott fotopolimer eltávolítása, ami a fotopolimerhez tartozó speciális elóhívó oldattal tehetô meg. A mikrostruktúrákat általában a fotopolimert hordozó fedőlemez felületéhez kötve fabrikálják, hogy az előhívás során ne mosódjanak el. 


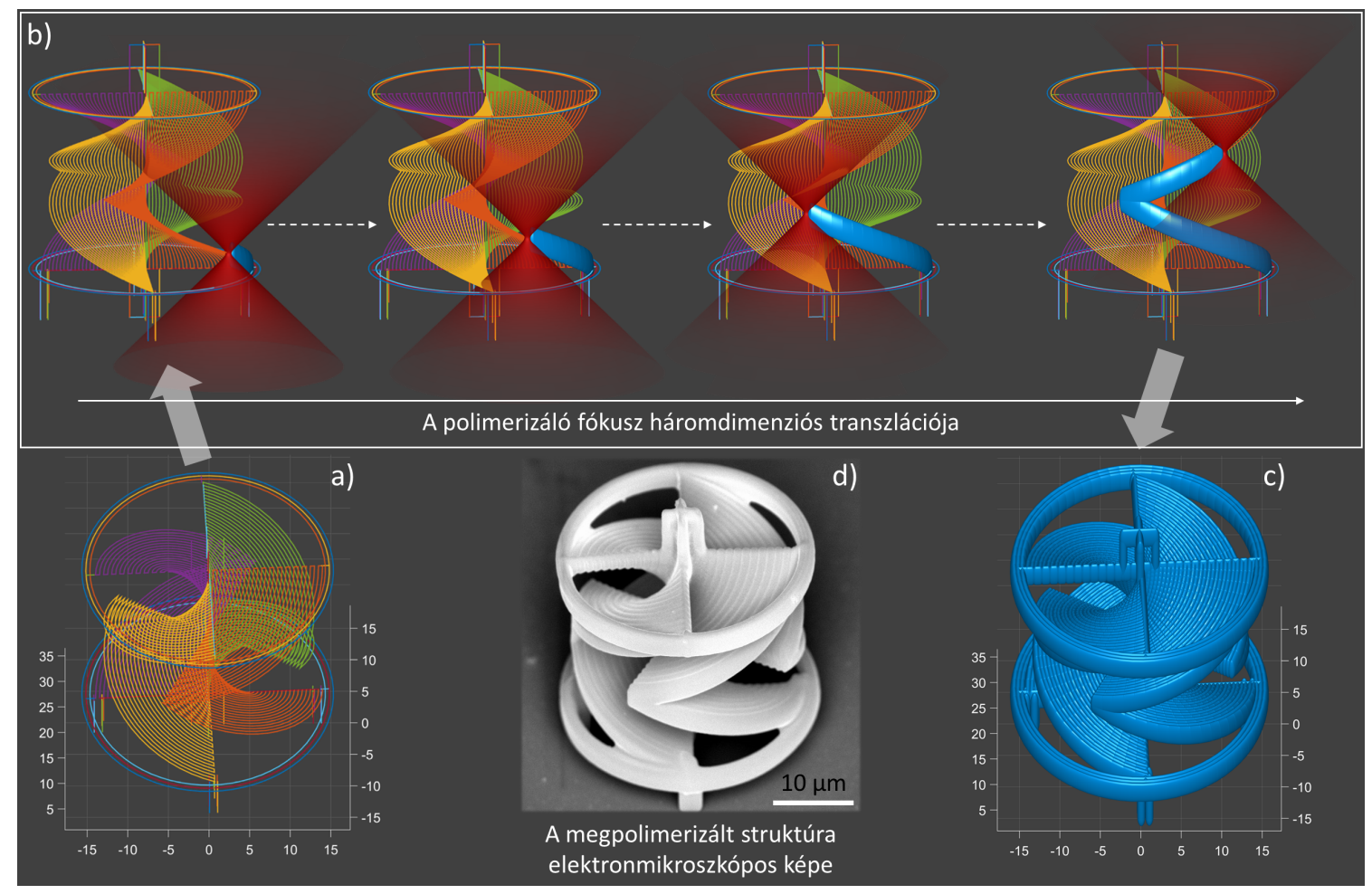

2.5. ábra. Egy mikrostruktúra lézeres két-fotonos polimerizációjának folyamata. a) A mikrostruktúrához tervezett három-dimenziós pásztázó útvonalak. b) A lézerfókusz az egyes 3D útvonalak mentén előrehaladva fokozatosan polimerizálja a struktúrát. c) Az összes útvonal exponálása után várható alakzat. d) A ténylegesen legyártott mikrostruktúra pásztázó elektronmikroszkópos képe [36].

\subsection{3. $\mathrm{SU}-8$ fotopolimer}

A két-fotonos polimerizációval megmunkálható fotopolimerek tára igen széles. A dolgozatomban bemutatott munkákban én kizárólag az SU-8 fotopolimert használtam fel, így arról adok egy rövid leírást az alábbiakban.

Az SU-8 egy UV-fényre reagáló fotopolimer, amelyet széles körben használnak fotolitográfiás eljárásokban, kiváló optikai és mechanikai tulajdonságai, valamint kémiai ellenálló-képessége és biokompatibilitása miatt. A fotopolimer három kémiai komponensból áll: szerves oldószerbe (ciklopentanon) kevert epoxigyanta monomer (EPON, Shell Chemical Company) és fotoiniciátor (triarilszulfónium-hexafluorantimonát), amely a fotopolimer fényérzékenységét biztosítja. Az SU-8 monomer komponense egy 8 epoxi csoportot tartalmazó molekula, amelyek mindegyike képes egy másik monomer molekula epoxi csoportjaival kapcsolódni. A fotopolimerizácó során a fotoiniciátor az elnyelt fotonok hatására protonálódik egy erôs savat képezve amely a monomerek epoxi gyưrúit felnyitva egymáshoz kapcsolja azokat (2.6 ábra).

A gyakorlatban az SU-8-at vékony réteg formájában üveg vagy szilícium hordozóra viszik fel, amely végén az oldószert melegítéssel elpárologtatva kiszárítják a réteget. Így egy könnyen kezelhetô szilárd SU-8 réteg kapható, amelyben minimális a megvilágítás 


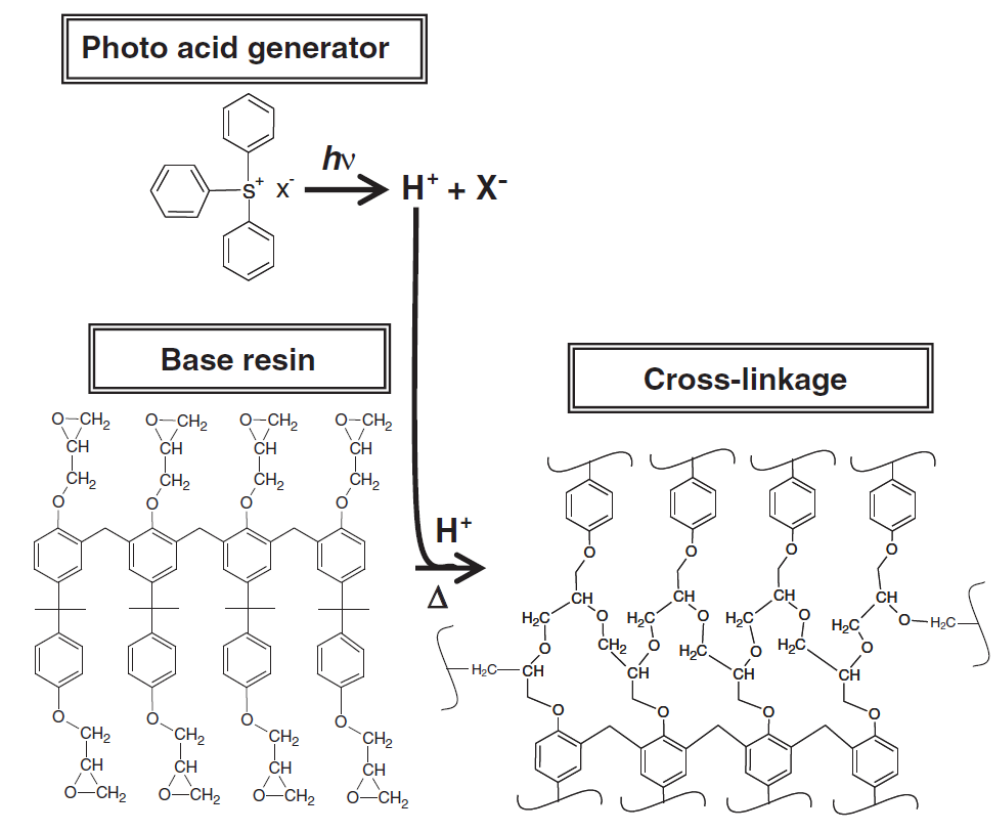

2.6. ábra. Az SU-8 fotopolimer monomerjének szerkezete, és fotopolimerizációjának kémiai folyamata [38].

során képződő fotoiniciátor-sav diffúziója, ami ronthatná a mikrofabrikáció felbontását. A megvilágítás után a réteget pár percig $95^{\circ} \mathrm{C}$ hômérsékletre kell melegíteni, hogy az aktivált fotoiniciátor molekulák reagálni tudjanak a monomerekkel és így végbemenjen a megvilágított SU-8 polimerizációja. A hókezelés után a nem polimerizálódott SU-8 egy előhívô oldószerrel (1-metoxi-2-propil-acetát) eltávolítható.

\subsection{Optikai csipesz}

\subsubsection{Bevezetés}

Az optikai csipesz egy olyan lézeres technika amellyel mikrométeres méretú dielektrikum részecskék csapdázhatóak egy erôsen konvergáló lézernyaláb fókuszában. A módszer a dielektrikum részecskére az elektromágneses sugárzás által kifejtett erókön alapul, amelyek a sugárzás mechanikai impulzusából származnak.

Johannes Kepler már a 17. században felvetette, hogy fénysugarak nyomást fejtenek ki az útjukba eső részecskékre, amit üstökösök csóvájának megfigyelésére alapozott. Ezt követően, Maxwell az elektromágneses sugárzás elméletének lefektetése során megmutatta, hogy az mechanikai impulzussal rendelkezik, ami következtében a sugárzás nyomást fejt ki az annak kitett felületekre. A sugárnyomás első kísérleti megfigyelését 1901-ben végezte el Lebegyev [39], illetve Nichols és Hull [40]. Kísérleteikben egy alacsony nyomású kamrában elhelyezett torziós szálra függesztett tükör elmozdulását figyelték meg megvilágítás hatására. Egy tükörről merólegesen visszaverődő fénynyaláb az impulzusának iránya megváltozása miatt $F=2 P / c$ nagyságú erốt fejt ki a tükörre, ahol $P$ a fénynyaláb tel- 
jesítménye, c pedig a vákuumbeli fénysebesség. Egy $1 \mathrm{~W}$ teljesítményü fénynyaláb esetén ez az erô mindössze $7 \mathrm{nN}$, így sokáig úgy tủnt, hogy a fénynyomás gyakorlati hasznosítása nem kivitelezhető.

Az 1960-as évektől a lézerek megjelenése és gyakorlati alkalmazásuk elterjedése új utat nyitott a fénynyomás hasznosítása irányában. A klasszikus fényforrásokkal szemben a lézerek könnyen lefókuszálhatóak egy szub-mikrométeres diffrakció-limitált pontba, ahol a koncentrált sugárnyomás már jelentős erôt fejthet ki mikroszkopikus testekre. A fenti koncepcióra alapuló lézeres optikai mikromanipuláció úttörője Arthur Ashkin, aki az 1960-as évek végén kezdett el a témán dolgozni. Első kísérleteiben [41] Ashkin vízben úszó, néhány mikrométer átmérôjû polisztirol golyók mozgását figyelte meg egy gyengén lefókuszált lézernyaláb sugárnyomásának hatására (2.7.a ábra). Leírta, hogy miközben a golyók a fénynyomás hatására várható módon a fényterjedés irányában előre haladnak, arra meróleges irányban a nyaláb nagyobb intenzitású tengelye felé is vonzódnak.

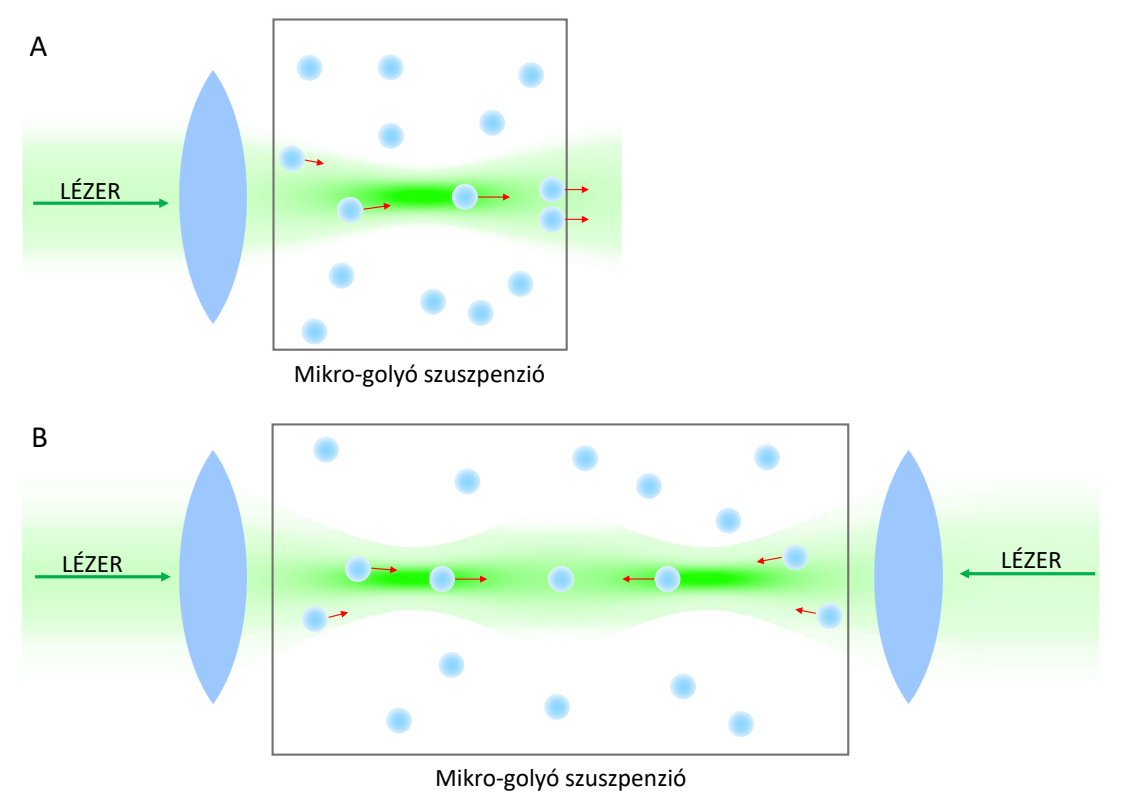

2.7. ábra. Arthur Ashkin elsố optikai csipesz kísérleteinek [41] sematikus rajzai. A piros nyilak a mikrogolyókra a fény által kifejtett eróket szemléltetik. a) Mikrométeres golyók szuszpenziójában terjedô fókuszált lézernyaláb a tengelyébe vonzza és terjedési irányába "fújja" azokat. b) Kettô egymással szemben haladó lézernyalábbal megvalósított három-dimenziós optikai csapdázás.

Ashkin a mikrogolyók e kettôs jellegú mozgását egy egyszerú sugároptikai modellel értelmezte (2.8 ábra). Képzeljünk el egy $\mathrm{TEM}_{00}$ profilú lézernyaláb A tengelyétôl oldalra elhelyezkedô mikrogolyót $\left(n_{H}=1.58\right)$, amelyet víz $\left(n_{L}=1.33\right)$ vesz körül. Vizsgáljunk meg kettő, a golyó $\mathbf{B}$ tengelyéhez képest szimmetrikusan elhelyezkedő fénysugarat $(\mathbf{a}, \mathbf{b})$. A fénysugarak a golyóba be- és kilépéskor a Fresnel-egyenletekkel leírható módon megtörnek, illetve visszaverődnek. A nyaláb tengelyéhez közelebbi, erősebb a fénysugár esetén a be- és kilépéskor a visszaverôdés következtében $\mathbf{F}_{\mathbf{R}}^{\mathbf{i}}$ és $\mathbf{F}_{\mathbf{R}}^{\mathbf{o}}$, valamint a fénytörés követ- 
keztében $\mathbf{F}_{\mathbf{D}}^{\mathbf{i}}$ és $\mathbf{F}_{\mathbf{D}}^{\mathbf{o}}$ ellenerôk lépnek fel. Bár ezen erôk nagysága jelentősen változik a fénysugarak elhelyezkedésével $(\phi)$, az alábbi eredmények kvalitatív módon megegyeznek minden $\phi$ értékre. A nyaláb tengelye mentén az erôk mindegyike a fényterjedés irányába esố gyorsulást eredményez $(+\mathbf{z})$. A radiális $(\mathbf{r})$ irányban a reflexiós erôk jóval kisebbek mint a fénytörésból ébredôek. Továbbá az $\mathbf{F}_{\mathbf{R}}^{\mathbf{i}}$ és $\mathbf{F}_{\mathbf{R}}^{\mathbf{o}}$ erốk radiálisan elsố rendben kiejtik egymást, míg az $\mathbf{F}_{\mathbf{D}}^{\mathbf{i}}$ és $\mathbf{F}_{\mathbf{D}}^{\mathbf{o}}$ erôk mind a $-\mathbf{r}$ irányban hatnak. Az erôsebb a fénysugár így radiálisan a nyaláb tengelye felé löki a mikrogolyót. Szimmetria okokból következően a gyengébb b fénysugár radiálisan ellenkező előjelû, de gyengébb erôt eredményez. Így látható, hogy összességében a mikrogolyó a fényterjedés irányában előre és a nyaláb tengelye felé lökődik.

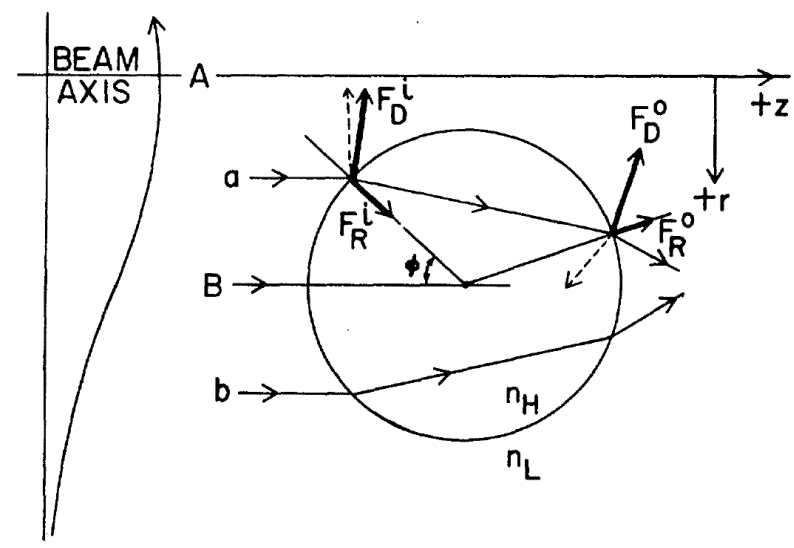

2.8. ábra. Geometriai optikai fényterjedés és a sugárnyomásból származó erôk egy TEM $\mathrm{TE}_{00}$ lézernyaláb tengelyétôl oldalra elhelyezkedő, vízben úszó mikrogolyó esetén [41].

Ashkin ebben a közleményében bemutatta a három-dimenzióban csapdázó optikai csipesz elsố megvalósítását is, amely kettő, egymással szemben haladó gyengén lefókuszált lézernyalábból állt (2.7.b ábra). A két lézernyaláb fókusza közötti térrészben a tengelyirányú sugárnyomás erôk kiegyenlítik egymást, így ott a mikrogolyók egy stabil egyensúlyi helyzetben csapdázhatóak, amelyből kitérés esetén visszatérítő erôk lépnek fel.

Fontos megjegyezni, hogy Ashkin már ebben, az optikai mikromanipuláció témájában elsố közleményében [41] leírta, hogy lézerek sugárnyomásával akár atomok és molekulák is manipulálhatóak, amely nyomán olyan forradalmi eredmények születtek mint atom nyalábok lézeres eltérítése [42,43], izotópok lézeres szétválasztása [44], atomok lézeres hútése [45,46] és a Bose-Einstein kondenzátum kísérleti megvalósítása [47].

Az optikai csipesz fent bemutatott, kettő szemben haladó lézernyalábon alapuló kezdeti verziója után Ashkin 1986-ban megmutatta [48], hogy egy megfelelően nagy numerikus apertúrájú fókuszáló lencse alkalmazásával egyetlen lézernyalábbal is lehetséges stabil három-dimenziós optikai csapdázás (2.9 ábra). Ennek alapja, hogy a nagy numerikus apertúrával lefókuszált csapdázó lézernyaláb fókuszában már az optikai tengely irányában is olyan erốs intenzitás gradiens jön létre, hogy az abból származó erố meghaladja 
a csapdázott objektumot a fényterjedés irányába lökô szóró eróket. A lézercsipesz ezen formája egyszerúsége (egyetlen lézernyaláb és fókuszáló lencse) mellett a legnagyobb csapdázó erôt biztosítja (nagy numerikus apertúrájú fókusz), így a módszer legelterjedtebben használt, napjainkra már klasszikus megvalósítása lett.

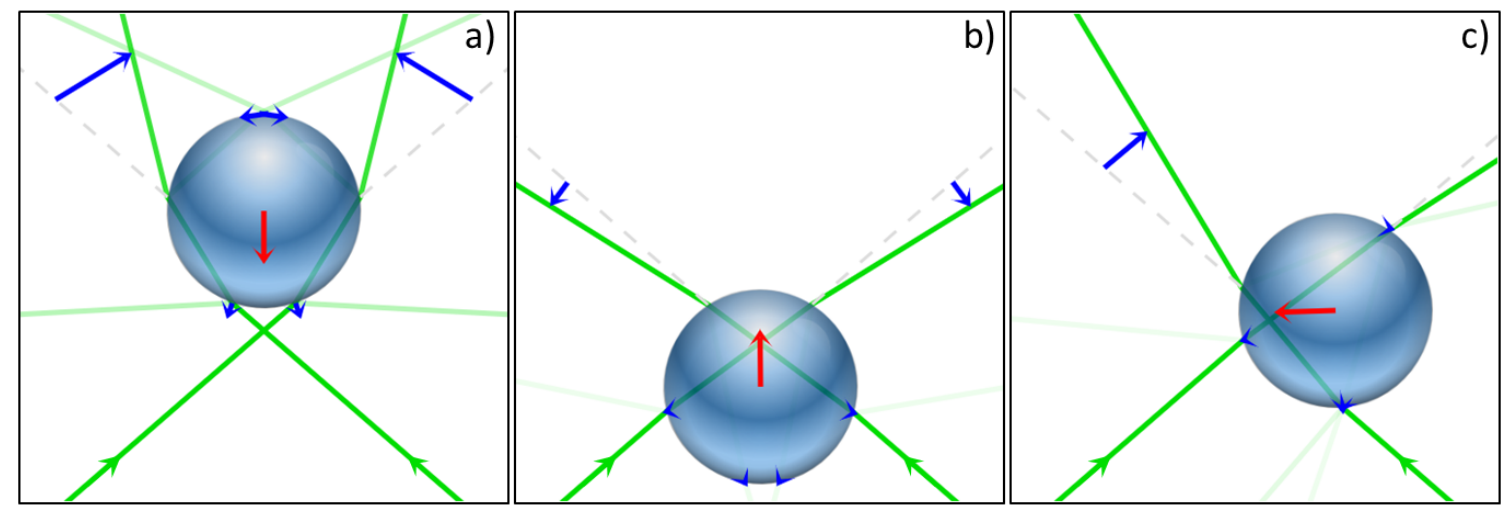

2.9. ábra. Egy mikrogolyó stabil három-dimenziós optikai csapdázásának demonstrációja kettô nagy numerikus apertúrával lefókuszált fénysugár geometriai optikai fényterjedése alapján [49]. A mikrogolyóra a fénysugarak momentum változása miatt fellépő eredő erôt a piros nyíl mutatja, amely bármely irányú kitérés esetén az egyensúlyi pozíció felé mutat (a-c).

A fent bemutatott geometriai optikán alapuló modellek (2.8 és 2.9 ábra) kvalitatív módon segítik megérteni a lézercsipesz múködését, de pontos, kvantitatív eredmények csak a hullámhossznál jóval nagyobb részecskékre $(d \gg \lambda)$ számolhatóak velük [50]. A lézercsipesz tipikus alkalmazásaiban a csapdázott objektum mérete a hullámhosszal összemérhetô (pl. mikrogolyó), amely mérettartományban az optikai csapda által kifejtett csapdázó erố pontos számolásához a Maxwell egyenletek vektori alakjának megoldása szükséges. Erre a legalkalmasabb módszerek az ún. általánosított Lorenz-Mie elmélet, amely homogén gömbökre alkalmazható, valamint az azon alapuló T-mátrix módszer [51,52], amely tetszóleges alakú objektumok számolására is használható.

\subsubsection{Holografikus optikai csipesz}

A lézercsipesz kísérletes felhasználása jelentôsen kiterjeszthetô olyan technikákkal, amelyek lehetôvé teszik több optikai csapda létrehozását egyetlen lézernyalábból. Erre eleinte számítógépról vezérelhetô, motorizált galvo tükröket [53], vagy akuszto-optikai deflektorokat [54] alkalmaztak, amelyek a csapdázó lézernyaláb irányának nagy sebességú változtatásával képesek annak fókuszát időosztásos módon, a fókuszsíkon belül több csapdapozícióba küldeni. Az 1990-es évek végén megjelent egy, az elóbbi kettônél jobbnak bizonyuló megoldás több optikai csapda generálására és három-dimenzióban való mozgatására, az ún. holografikus optikai csipesz $[7,8]$.

A holografikus optikai csipesz alapja egy számítógéprôl vezérelhető térbeli fázismodulátor (2.10 ábra, SLM), amellyel a csapdázó lézer hullámfrontja nagy felbontással, 


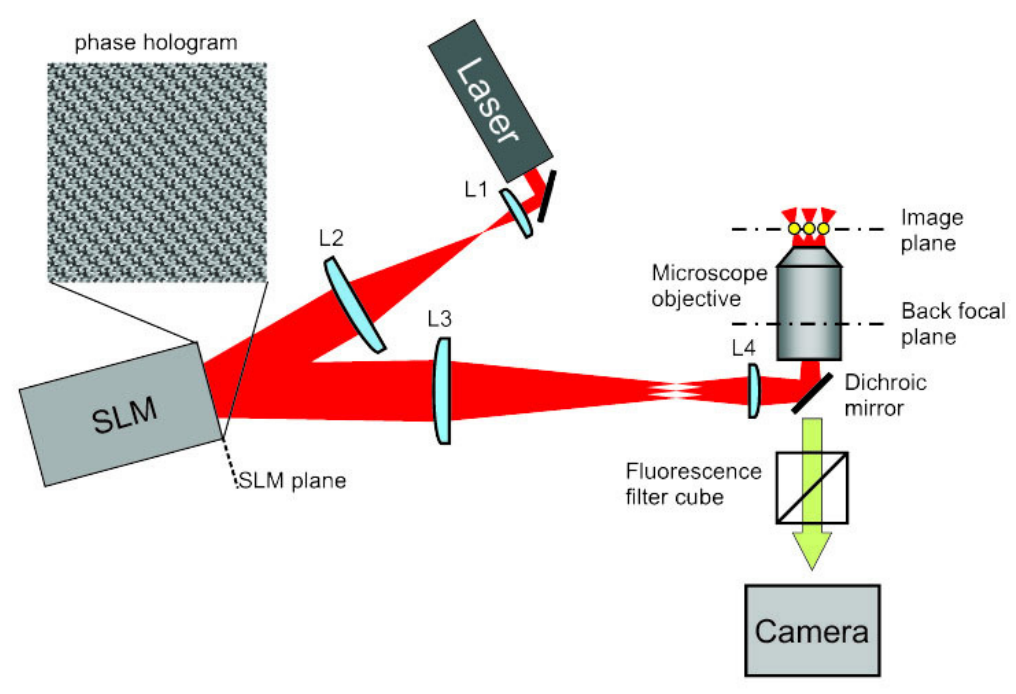

2.10. ábra. Egy holografikus optikai csipesz sematikus felépítése [55].

dinamikusan alakítható az eszközre küldött két-dimenziós vezérlő hologramok mintájára. Az így megvalósított holografikus lézernyaláb formázással lehetséges nagy számú, háromdimenzióban egymástól függetlenül mozgatható optikai csapda létrehozása egyetlen lézernyalábból. A csapdázó lézer hullámfrontjának tetszóleges módosításának lehetôsége további előnyöket is nyújt: létrehozhatóak akár Bessel [56,57], vagy Laguerre-Gauss [58] módusú nyalábok, valamint az optikai rendszerben fellépó aberrációk is kompenzálhatóak $[59,60]$.

\subsection{Holografikus lézernyaláb formázás}

A lézerek fejlődése számos új vizsgálati módszernek és mérési technikának nyitott utat. Legalább ilyen fontos az olyan technikák fejlődése, amelyek lehetôvé teszik a lézernyalábok különbözô paramétereinek modulálását, alakítását. Ezek közé tartozik a lézernyalábok holografikus alakítása, amely során egy lézernyaláb hullámfrontja egy megszabott fázistolásmintázatnak, azaz hologramnak megfelelően módosul. A legegyszerúbb hologramok az optikai rácsnak, illetve lencsének megfelelő fázistolás mintázatok, amelyekkel megváltoztatható egy lézernyaláb iránya, illetve divergenciája. A holografikus nyalábformálást leggyakrabban a 2.11 ábrán szemléltetett 2f optikai elrendezésben valósítják meg.

Az ilyen elrendezésben egy párhuzamos lézernyaláb sík hullámfrontja egy lencse hátsó fókuszsíkjában elhelyezett holografikus optikai elem által módosul. A fázismodulált nyalábot ezután a lencse az elülsô fókuszsíkjába képezi. A 2f elrendezés előnye, hogy a nyaláb komplex amplitúdója a lencse elülső fókuszsíkjában a hátsó fókuszsíkbeli komplex amplitúdó Fourier-transzformáltja. Ez a reláció megkönnyíti olyan hologramok numerikus számolását amelyek az elülsô fókuszsíkban egy megszabott intenzitás eloszlást hoznak 


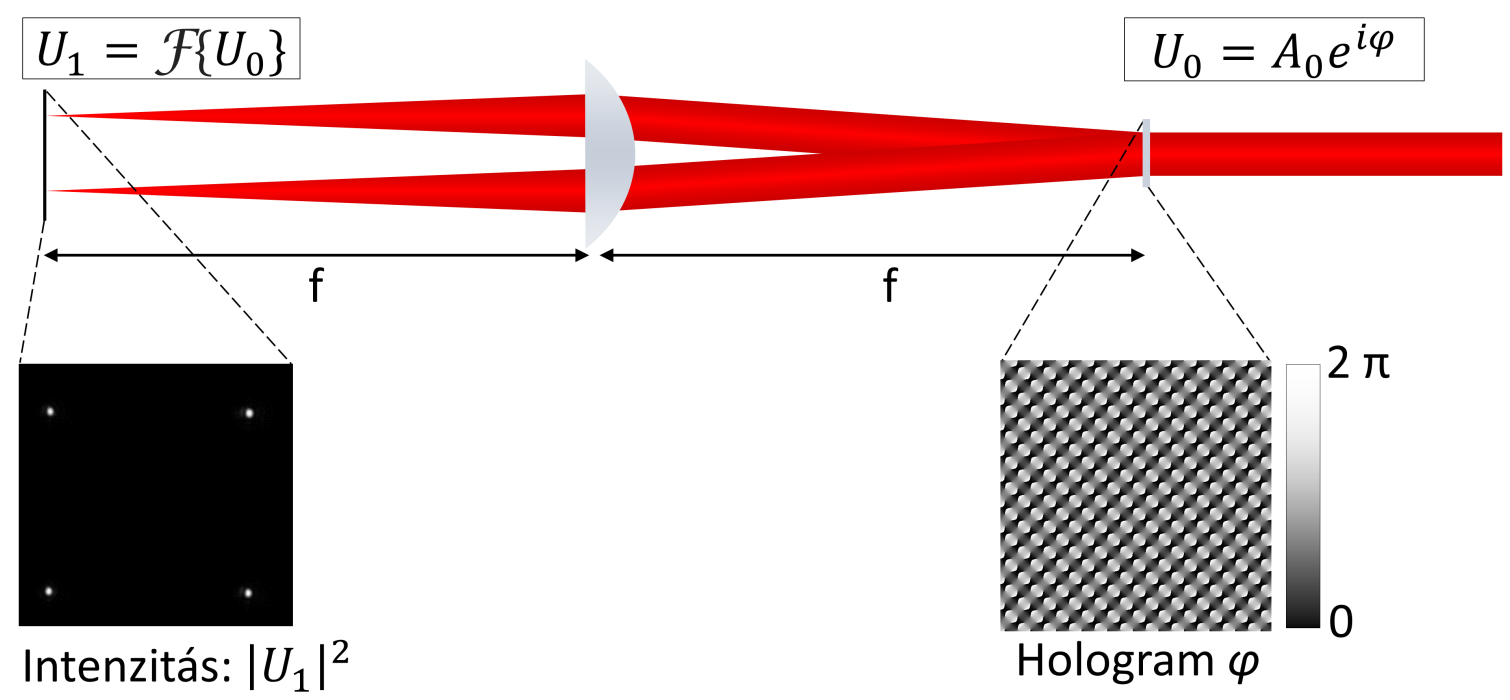

2.11. ábra. Egy lézernyaláb holografikus formázása lencsés 2 f optikai elrendezésben. A lencse első fókuszsíkjában előálló $U_{1}$ komplex amplitúdó a hátsó fókuszsíkbeli fázismodulált komplex amplitudó $\left(U_{0}\right)$ Fourier-transzformáltja, a 2f optikai elrendezés miatt. Az ábrán látható hologram $(\varphi)$ az eredeti lézernyalábot 4 nyalábra bontja amelyek az elülső fókuszsíkban 4 elkülönülố helyre fókuszálódnak.

létre.

A hullámfrontot módosító hologram többféle fizikai formában valósítható meg. A legegyszerúbbek a statikus fázistolásmintázatot hordozó, ún. diffraktív optikai elemek. Ezek olyan reflektív felületek vagy transzmisszív rétegek amelyek felületi kiemelkedéseik mintázata vagy törésmutató mintázatuk révén módosítják a róluk visszaverôdő, illetve rajtuk áthaladó nyalábok hullámfrontját. A statikus diffraktív optikai elemek mellett léteznek dinamikusan változtatható hullámfront modulációra képes eszközök is, amelyek két csoportra oszthatóak: mikroelektromechanikai alapú deformálható tükrök [61,62], és a folyadékkristály alapú (Liquid Crystal on Silicon (LCOS)) térbeli fázismodulátorok [63]. A mikroelektromechnanikus tükrök nagy frissítési frekvenciával $(\sim \mathrm{kHz})$ rendelkeznek, felbontásuk azonban nem haladja meg a néhány ezer darab tükör elemet. Ezen eszközök fô alkalmazási területe a valósidejû hullámfront korrekció, amit például számos nagy csillagászati távcsônél alkalmaznak a légkör torzító hatásának kompenzálására. Az LCOS térbeli fázismodulátorok alacsonyabb frissítési frekvencia mellett jóval nagyobb felbontással bírnak: tipikus felbontásuk 1000 x 1000 fázismoduláló pixel elem, 60 Hz frissítési frekvencia mellett. Az ilyen eszközök ideálisak olyan alkalmazásokra, ahol elônyös a nagy felbontású hullámfront formázás lehetősége, de nincs szükség annak nagy frekvenciájú változtatására. A holografikus optikai csipesz rendszerekben legelterjedtebben LCOS térbeli fázismodulátorokat alkalmaznak. 
a)

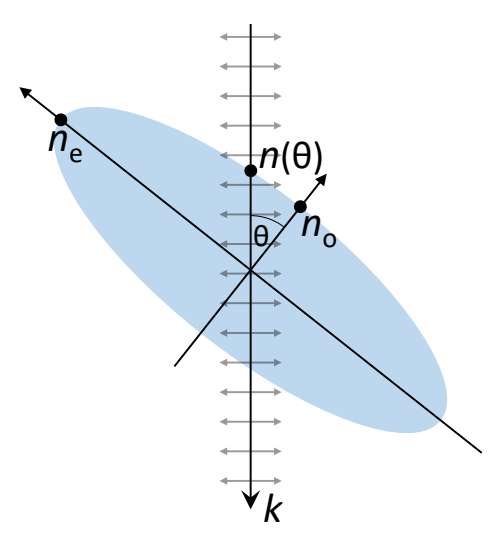

b)

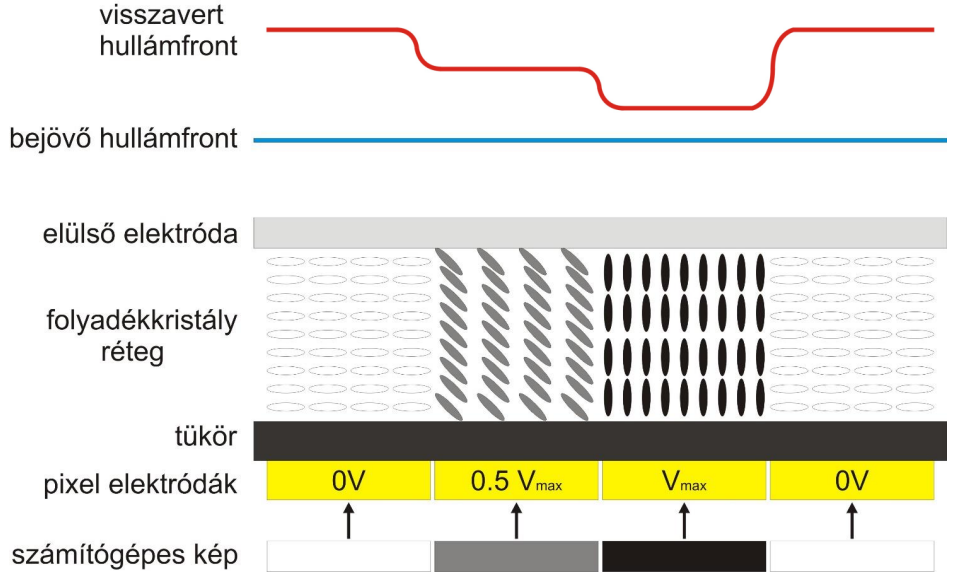

2.12. ábra. a) Egytengelyư kettőstörő folyadékkristály index ellipszoidja. b) Egy reflektív LCOS SLM szerkezetének keresztmetszete. Az elülső közös elektróda és a pixel elektródák közé zárt folyadék kristály molekulák a lokális elektromos tér nagyságával arányosan igyekeznek annak irányába beállni.

\subsubsection{LCOS Térbeli fázismodulátorok}

Az LCOS térbeli fázismodulátorok (SLM) folyadékkristály mikrokijelzókön alapulnak. A CMOS félvezetố technológiával készülő SLM-ek egy folytonos réteg nematikus folyadékkristályt tartalmaznak, amelyen belül a kijelzô pixel elektródái lokálisan változtatható elektromos teret hoznak létre (2.12.b ábra). A folyadékkristály réteg egytengelyư kettôstöró molekulákból áll, amelyek elektromos tér hiányában az elektródákkal párhuzamosan orientálódnak, bekapcsolt elektromos tér esetén pedig a feszültség növelésével egyre jobban beállnak a tér irányába (az elektródákra merőlegesen). A molekulák kettőstörô jellege miatt orientációjukkal csatoltan a pixelekre meróleges irányba esô törésmutatójuk is megváltozik (2.12.a ábra). Egy folyadékkristály pixelben az SLM felületére meróleges $k$ hullámvektorral haladó, a molekulák hosszanti tengelyével egy síkba esố polarizációjú fény így egy

$$
n(\theta)=\frac{n_{e} n_{o}}{\sqrt{\cos ^{2} \theta n_{e}^{2}+\sin ^{2} \theta n_{o}^{2}}}
$$

törésmutatójú közegben fog haladni, ahol $\theta$ a folyadékkristály molekulák tengelye és a fénysugár $k$ hullámvektora által bezárt szög, $n_{o}$ és $n_{e}$ a folyadékkristály ordinárius, illetve extraordinárius törésmutatója [64].

Az LCOS SLM-ek általában reflektív eszközök (2.13. ábra), amelyet a pixel elektródák elé helyezett dielektromos tükör biztosít (2.12.b ábra), illetve maguk a pixel elektródák is múködhetnek tükörként. Egy pixel által visszatükrözött fénynyaláb a folyadékkristály molekulák orientációjától függố

$$
\Delta \phi=2 \pi \frac{2 d}{\lambda}\left(n(\theta)-n_{o}\right)
$$


fázistolást szenved (a nulla feszültségú pixelekhez viszonyítva), ahol $d$ a folyadékkristály réteg vastagsága, $\lambda$ a fény hullámhossza.

A legelterjedtebb LCOS SLM típusok elektronikusan, számítógéprôl vezérelhetôek, többnyire digitális videó interfészen (HDMI, DVI) keresztül. A fázismoduláló hologramok szürkeskálás (tip. 8bit) képek formájában küldhetôek az SLM-re, amelynek vezérlő elektronikája a hologram kép pixelértékeit egy kalibrációs görbe alapján az SLM pixelein alkalmazott feszültségekké konvertálja, úgy, hogy a szürkeskálás pixelértékek lineárisan megfeleljenek $[0,2 \pi]$ tar-

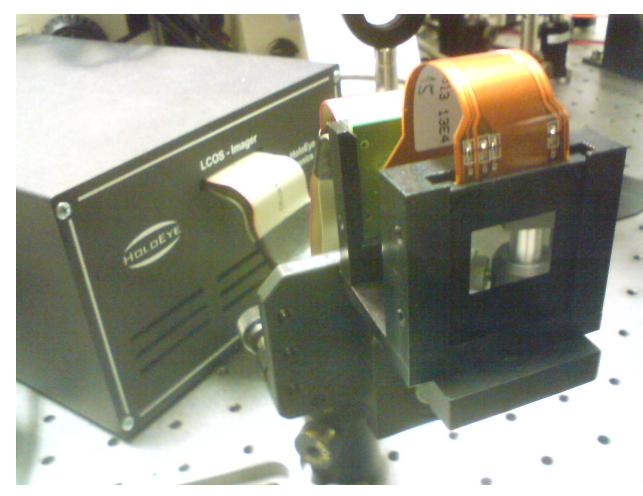

2.13. ábra. HOLOEYE LCR-2500 LCOS SLM. tománybeli fázistolásoknak. A legtöbb modellen $60 \mathrm{~Hz}$-el frissíthető az alkalmazott hologram. A térbeli fázismodulátorok fő gyártói a HOLOEYE Photonics AG [65], a Hamamatsu Photonics K.K. [66] és a Meadowlark Optics, Inc. [67] vállalatok.

\subsubsection{Több fókuszpont holografikus előállítása}

A térbeli fázismodulátorok egyik fố alkalmazási területe több fókuszpont létrehozása egyetlen lézernyaláb holografikus szétosztásával (2.11 ábra). Az ehhez szükséges hologram számolásának hátterét Roberto Di Leonardo és munkatársai közleményei [68,69] alapján mutatom be.

Egy 2 f elrendezésben alkalmazott SLM esetén (2.14 ábra) a lézernyalábot egy adott helyzetű fókuszpontba térítő hologram a következôképpen számolható:

$$
\Delta_{j}=\frac{2 \pi}{\lambda f}\left[x_{j} X+y_{j} Y+Z \sqrt{f^{2} n_{i}^{2}-\left(x_{j}^{2}+y_{j}^{2}\right)}\right]
$$

ahol $\Delta_{j}$ és $x_{j}, y_{j}$ az SLM (azaz a hologram) j-edik pixelének fázistolása és koordinátái, $X, Y, Z$ a fókuszpont koordinátái a lencse fókuszsíkjának közepétől mérve, $f$ az alkalmazott lencse fókusztávolsága, $n_{i}$ a lencse immerziós folyadékjának törésmutatója. A 2.6 egyenlet $X$ és $Y$ koordinátákat tartalmazó tagja egy megdôlt hullámfrontnak megfelelő fázistolás mintázatot eredményez, amely a fókuszpontot az optikai tengelyre meróleges síkban pozicionálja. A holografikus fókusz $Z$ koordinátájával megszorzott tag egy gömbi hullámfrontot létrehozó hologramot állít elô. Érdemes megjegyezni, hogy ez a z-irányú pozicionálásáért felelős tag általában, a paraxiális közelítés alkalmazása miatt, egy radiálisan kvadratikus hullámfrontként van definiálva [68]. A lézercsipesz és két-fotonos polimerizációs rendszerekben alkalmazott nagy numerikus apertúrájú mikroszkóp objektív lencsék esetén azonban egy szférikus hullámfrontot létrehozó hologram szükséges a holografikus fókuszpont precíz z-irányú pozicionálásához [70].

Olyan hologram, amely az eredeti lézernyalábot több fókuszpontba irányítja, legegy- 


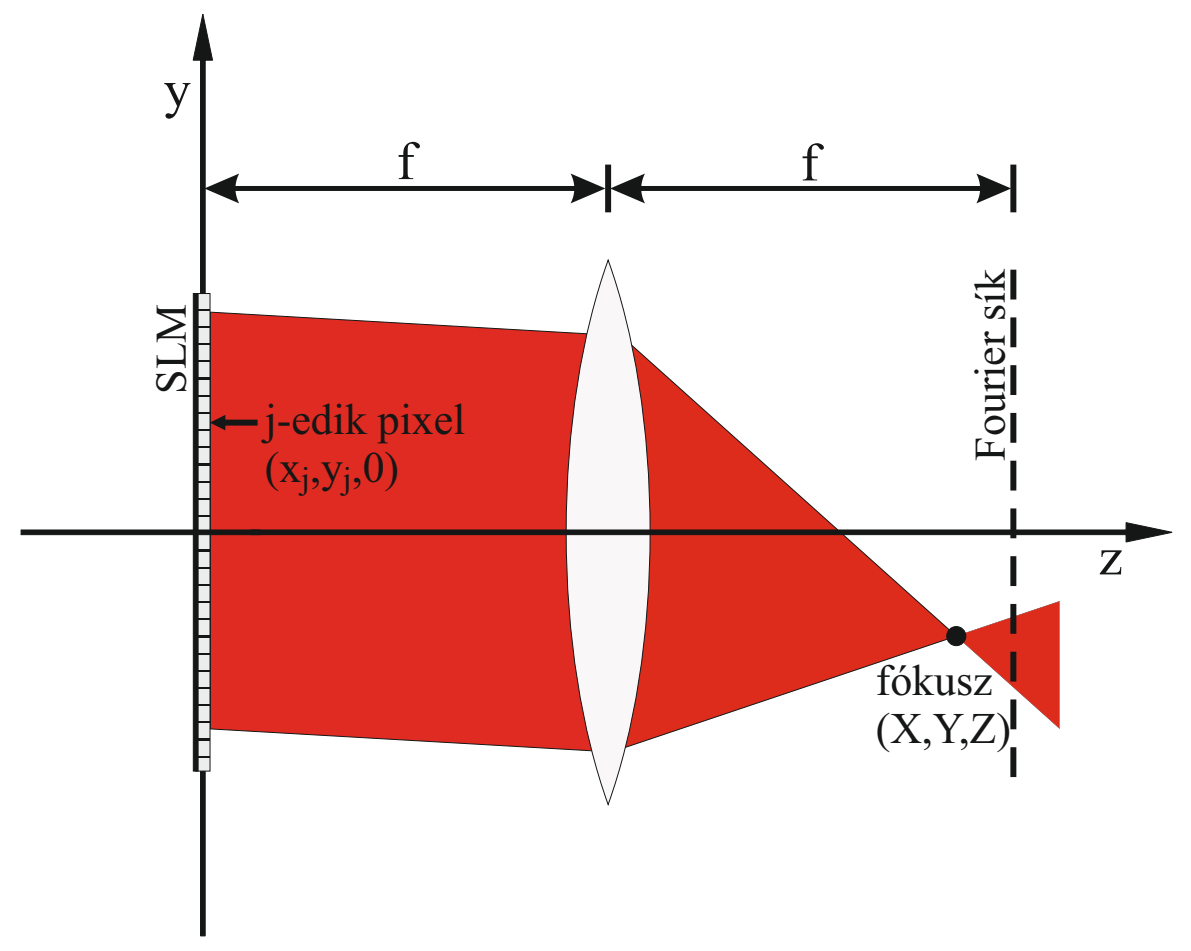

2.14. ábra. Fourier-optikai fényterjedés egy SLM-et alkalmazó holografikus 2 f optikai rendszerben [68]. Az egyszerúség kedvéért csak az SLM-rôl visszavert fázismodulált lézernyaláb van ábrázolva.

szerúbben az egyes fókuszok 2.6 egyenlet alapján számolt hologramjainak szuperpozíciójaként számolható:

$$
\phi_{j}=\arg \left[\sum_{m} e^{i \Delta_{j}^{m}}\right]
$$

A skalárdiffrakció elméletét felhasználva, az egyes holografikus fókuszokba jutó teljesítmény jellemzésére felírható a következô dimenzió nélküli mennyiség:

$$
V_{m}=\frac{1}{N} \sum_{j=1}^{N} e^{i\left(\phi_{j}-\Delta_{j}^{m}\right)}
$$

ahol $N$ a hologram pixeleinek száma. $I_{m}=\left|V_{m}\right|^{2}$ megadja, hogy az $m$ indexú holografikus fókusz pozíciója körüli diffrakció limitált területre az eredeti lézernyaláb teljesítményének mekkora része jut. $V_{m}$-et felhasználva célszerú a nyalábosztó hologramot 2 mennyiséggel jellemezni, az $e$ hatásfokkal és a holografikus fókuszok $u$ uniformitásával:

$$
e=\sum_{m} I_{m} \quad u=1-\frac{\max \left[I_{m}\right]-\min \left[I_{m}\right]}{\max \left[I_{m}\right]+\min \left[I_{m}\right]}
$$

Di Leonardo és munkatársai [68] megmutatták, hogy a 2.7 egyenlettel számolt szuperpozíciós hologram tipikusan $e=0.29$ hatásfokkal és $u=0.01$ uniformitással jellemezhetó, 
vagyis a teljes lézerteljesítmény kevesebb mint 30 \%-a jut a holografikus fókuszokba, amelyek teljesítménye két nagyságrendbeli tartományon különbözik.

Jelentôsen jobb minőségú, szinte maximális hatásfokú és uniformitású hologramok számolhatóak az ún. súlyozott Gerchberg-Saxton algoritmussal (GSW), amely az eredeti algoritmus [71] Di Leonardo és munkatársai által holografikus fókuszpontok előállítására tökéletesített változata. A GSW egy iteratív algoritmus, ami a nyalábosztó hologramot az egyes fókuszok hologramjainak súlyozott szuperpozíciójaként állítja elő:

$$
\phi_{j}=\arg \left[\sum_{m} w_{m} e^{i\left(\Delta_{j}^{m}+\theta_{m}\right)}\right]
$$

ahol $w_{m}$ és $\theta_{m}$ az $m$-edik fókusz súlya, illetve fázisa. A GSW iterációja kezdetén minden fókusz súlya 1 , míg fázisaik a $[0,2 \pi]$ tartományon véletlenszerüen kiválasztott értékek. Az iteráció minden lépésében $w_{m}$ és $\theta_{m}$ az egyes fókuszok helyén számolt komplex amplitúdó $\left(V_{m}\right)$ alapján módosul:

$$
w_{m}=w_{m} \frac{\left\langle\left|V_{m}\right|\right\rangle}{\left|V_{m}\right|} \quad \theta_{m}=\arg \left(V_{m}\right)
$$

ahol \langle\rangle az összes fókuszra vett átlagot jelenti. Az iteráció előrehaladtával a fókuszok súlyai és fázisai úgy optimalizálódnak, hogy az egyes $\left|V_{m}\right|$ értékek eltérései az átlagtól $\left(\left\langle\left|V_{m}\right|\right\rangle\right)$ csökkenjenek.

A GSW algoritmus tipikusan már 10 iteráció után olyan optimalizált hologramot eredményez, amelynek hatásfoka $e \approx 0.9$, valamint uniformitása $u \approx 0.99$. Így látható, hogy a GSW algoritmus ideális választás tetszôleges számú, egyforma teljesítményú holografikus fókusz előállítására. 


\section{EREDMÉNYEK}

\subsection{Holografikus két-fotonos polimerizáció}

\subsubsection{Bevezetés}

A két-fotonos polimerizáció (TPP) módszerével tetszóleges alakú három-dimenziós mikrostruktúrák készíthetőek, amelynek folyamata során egy polimerizáló lézer fókusz megszabott pásztázó útvonalak mentén haladva szekvenciálisan exponálja a kívánt mikrostruktúrát egy fotopolimer anyagba (lásd 2.5 ábra). A TPP folyamata a mikrostruktúrák méretétôl és összetettségétől függóen néhány perctôl akár egy óráig is eltarthat, így nagy számú mikrostruktúra készítése rendkívül idôigényes lehet.

A TPP rendszerekben általában jóval nagyobb lézerteljesítmény áll rendelkezésre, mint amennyi egyetlen polimerizáló fókuszhoz szükséges, így a TPP folyamatának felgyorsítására egyszerú megoldás lehet a polimerizáló lézer elosztása több fókuszba, megnövelve a rendelkezésre álló lézerteljesítmény kihasználtságát. Ez többféle optikai elem használatával is megvalósítható, mint például statikus hologramok [72], mikrolencse mátrixok [73,74], vagy a lézernyaláb hullámfrontját, illetve amplitúdó profilját moduláló térbeli fénymodulátorok [14,75-77]. Ezekben az esetekben a többszörös fókuszok statikus két-dimenziós elrendezésekben jönnek létre, a TPP folyamata során minden fókusz egyazon mikrostruktúrának egy különálló másolatát hozza létre.

A lézernyaláb hullámfrontját moduláló folyadékkristály alapú térbeli fázismodulátorokkal (SLM) nem csak statikusan két-dimenzióban, hanem dinamikusan három-dimenzióban is létrehozható nagy számú lézerfókusz. Ezek az eszközök az alapjai a holografikus optikai csipesznek, ahol lehetôvé teszik több, valós időben mozgatható optikai csapda létrehozását [69]. Ennek fényében Jenness és munkatársai egy SLM-et felhasználva demonstrálták, hogy holografikusan létrehozott és mozgatott fókuszokkal lehetséges egy mikrostruktúra párhuzamosan több példányban történô egy-fotonos polimerizációs fabrikációja [78]. Két-fotonos polimerizáció esetén azonban még nem történt ilyen irányú fejlesztés, valamint egyetlen mikrostruktúra több holografikus fókusz általi polimerizációját se valósították még meg.

Ebben a munkámban a két-fotonos polimerizáció egy olyan új módját mutatom be, ahol egyes mikrostruktúrák párhuzamosan több holografikus fókusz egymástól független, koordinált mozgatása révén polimerizálódnak. Ez egy számítógéprôl vezérelt, elektroni- 
kusan címzett SLM folytonos frissítésével valósul meg, úgy, hogy az eszközre egymást követôen küldött hologramok által létrehozott fókuszok fokozatosan exponálják a kívánt mikrostruktúra egymást követő részeit. A hologramokat az SLM $60 \mathrm{~Hz}$ frissítési frekvenciájával valós időben számolja ki egy általam írt C++/CUDA szoftver, kihasználva egy NVIDIA CUDA technológiájú grafikus kártya számítási teljesítményét. A módszer demonstrációjához egy egymásba ágyazott dodekaéderekból álló teszt mikrostruktúrát terveztem. Mivel egy dodekaéder ötfogású szimmetriával rendelkezik, a teszt struktúra 5 egyenlő részre bontva, 5 holografikus fókusz által polimerizálódott.

\subsubsection{Kísérleti elrendezés}

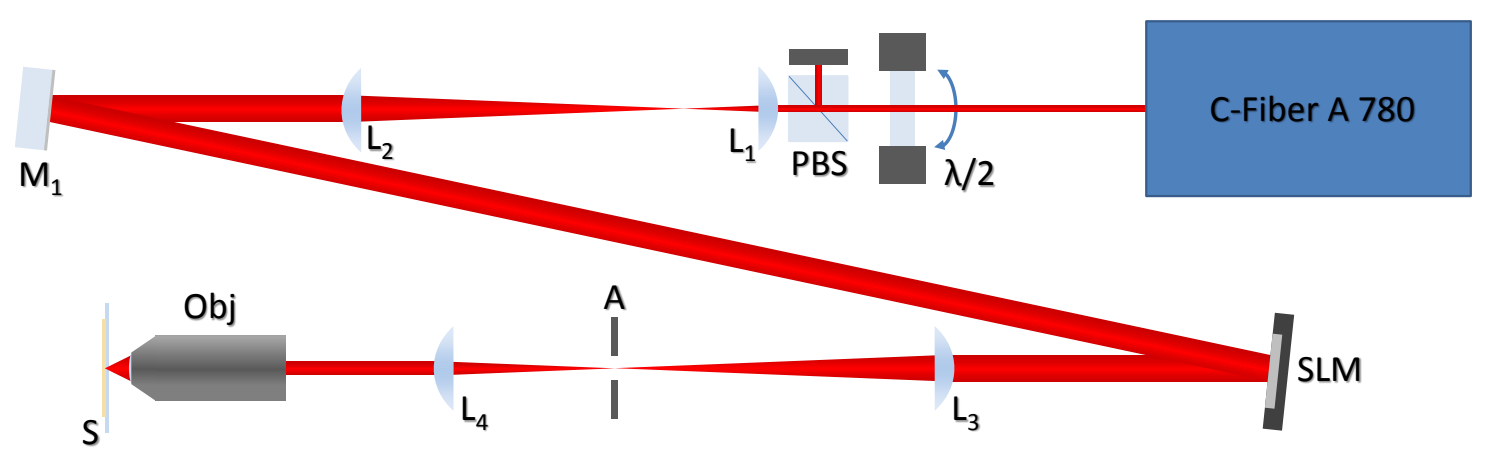

3.1. ábra. A holografikus két-fotonos polimerizációs rendszer felépítésének sematikus rajza.

A 3.1 ábrán látható a holografikus TPP rendszer sematikus rajza. A rendszer fényforrása egy femtoszekundumos szállézer (C-Fiber A 780, Menlo Systems, Németország) amely $100 \mathrm{MHz}$ ismétlési frekvenciával állít elő 100 fs hosszú lézerimpulzusokat $780 \mathrm{~nm}$ hullámhosszon. Az alkalmazott lézerteljesítmény egy forgatható tartóba foglalt félhullám lemez $(\lambda / 2)$ és a közvetlenül utána elhelyezett polarizációs nyalábosztó kocka (PBS) kombinációjával állítható. Egy lencsepár $\left(L_{1}, L_{2}\right)$ által alkotott nyalábtágító megnöveli a lézernyaláb méretét, hogy az kitöltse a rendszerbe épített SLM (LCR-2500, Holoeye Photonics AG, Németország) aktív tükröző felületét. Az SLM-rôl visszavert hullámfront formázott nyalábot egy 4f lencse pár $\left(L_{3}, L_{4}\right)$ egy olajimmerziós mikroszkóp objektív (Zeiss Achroplan 1.2 NA 100x, Carl Zeiss, Németország) (OBJ) hátsó fókuszsíkjába képezi, amely egy Zeiss Axiovert 40 mikroszkópra van felszerelve. A holografikus nyalábformázás során fellépố nulladik és az egyéb nem kívánt magasabb diffrakciós rendeket az $L_{3}$ lencse fókuszsíkjában egy apertúrával (A) ki lehet takarni. Azt itt átengedett elsô diffrakciós rendeket az objektív a mikroszkópra rögzített tartóba helyezett fotopolimer mintába (S) fókuszálja, amit egy léptetô motoros mintaasztallal lehet laterálisan pozicionálni (LS-2000, Märzhäuser Wetzlar GmbH \& Co., Németország).

A teszt mikrostruktúrákat SU-8 fotopolimerból (Microchem, USA, 2007-es típus) készítettem, amit egy 20 mikrométer vastag réteg formájában egy mikroszkóp fedólemez 
hordozott. A TPP végén a fotopolimer minta tíz perces hókezelést kapott $100{ }^{\circ} \mathrm{C}$-on, ami után az SU-8 elóhívó oldószerében, majd etanolban háromszor 5 percig ázott. Mivel az SU-8 fotopolimerben nem történik törésmutató változás a TPP lézeres exponálása során, a mikrostruktúrák kialakulása nem figyelhetô meg optikai mikroszkópiával. Ezért a német Nanoscribe GmbH által gyártott IPL fotopolimert is használtam, amely a megvilágításra történố törésmutató változása révén lehetôvé teszi a holografikus TPP folyamatának lefilmezését.

A holografikus polimerizációt vezérlő szoftver egy NVIDIA Geforce GTX 560 Ti grafikus kártyával felszerelt asztali számítógépen futott. A rendszerbe épített SLM a számítógép videokártyájára kötve, annak digitális videó interfészén (DVI) keresztül volt vezérelve, 8 bites szürke-skálás hologram képekkel.

\subsubsection{A holografikus TPP folyamata}

A párhuzamosan több holografikus lézer fókusz által történő TPP precíz megvalósításához olyan hologramok szükségesek, amelyek pontos három-dimenziós koordinátákban közel egyenlő intenzitású fókuszokat hoznak létre. Ilyen hologramok számolására a 2.3.2 alfejezetben bemutatott súlyozott Gerchberg-Saxton (GSW) algoritmus a legmegfelelóbb. A GSW egy iteratív algoritmus, amely tipikusan 10 iteráció alatt már olyan optimalizált hologramot eredményez, amely 99\%-ban uniform intenzitású fókuszokat hoz létre. Az algoritmus hátránya azonban a számításigénye, még egy több szálon futó, optimalizált programkóddal is jó néhány másodperc a számolás ideje. Ez nem szükségszerúen probléma a holografikus TPP megvalósításánál, egy mikrostruktúra teljes exponálásához szükséges hologramok elôre is kiszámolhatóak és elmenthetőek, ez azonban viszonylag nagy tárhely kapacitást igényelne, valamint csökkentené a módszer flexibilitását is.

Az utóbbi tíz évben széles körben elterjedt a grafikus kártyákon alapuló nagy teljesítményû számítás, amelyek közül kiemelkedik az NVIDIA által kifejlesztett CUDA technológia. A CUDA technológia lehetôvé teszi az NVIDIA grafikus kártyákon található nagy számú (akár több 1000), párhuzamosan dolgozó processzor mag kihasználását tetszőleges számítási feladatokra, ami által akár több százszoros számítási sebesség növekedés érhető el. Egy NVIDIA CUDA grafikus kártya képességeit kihasználva a GSW algoritmus számolási sebessége is drasztikusan felgyorsítható [69], így én magam is megírtam az algoritmus CUDA implementációját. Egy 384 darab 1.6 GHz-es processzor maggal rendelkezô NVIDIA GTX 560Ti grafikus kártyát felhasználva körülbelül 100x gyorsulást sikerült elérni. A GPU alapú számolással így lehetségessé vált a hologramok valós idejú generálása, az SLM $60 \mathrm{~Hz}$ frissítési frekvenciáját követve akár 10 holografikus fókusz is dinamikusan mozgatható (10 iteráció mellett).

A holografikus TPP-t egy C++/CUDA nyelven írt szoftver irányította, amely magába foglalta a GPU alapú hologram számolást, a hologramot az SLM-en megjelenítő OpenGL 
ablakot, valamint a fotopolimer mintát pozicionáló motorizált mikroszkóp asztal irányítását. A FreeGLUT [79] programkönyvtárral létrehozott OpenGL ablak lehetôvé teszi a GPU-n számolt hologramok közvetlen megjelenítését az SLM-en a GPU DRAM memóriájából, mindössze $0.05 \mathrm{~ms}$ alatt. A szoftver indításakor betölti a kívánt mikrostruktúra megvilágítandó pontjait tartalmazó koordináta fájlt, valamint egy másik, a mikroszkóp motorizált asztalának pozícióit tartalmazó fájlt, ami a mikrostruktúra több példányban történô automatizált gyártásához használható. A mikrostruktúra koordináta fájljában a koordináta pontok csoportokba vannak rendezve, úgy, hogy az egyazon csoportba tartozó pontokat exponáló fókuszok egyazon hologram által jönnek létre. A holografikus polimerizáció során az összes csoporton végighaladva, az SLM-en sorban egymás után megjelenítődnek az egyes csoportok pontjaira számolt hologramok. Így az SLM $60 \mathrm{~Hz}$ frissítését követve, minden 16.66 ms elteltével a holografikus fókuszok új, még nem exponált koordináta pontokban jelennek meg. A holografikus fókuszok diffrakció limitált minőségének érdekében minden hologramhoz hozzáadódik egy korábban megmért [14], az SLM felületi torzulását kompenzáló korrekciós hologram. A holografikus TPP precizitásának érdekében szükséges, hogy minden hologram ugyanannyi ideig legyen megjelenítve az SLM-en. Ez elérhetô az ún. vertikális szinkronizáció ("v-sync") bekapcsolásával az OpenGL ablakra [80], amely biztosítja, hogy az OpenGL ablak az SLM frissítésével szinkronban rajzolódjon ki.

\subsubsection{Eredmények}

A dodekaéder teszt mikrostruktúra koordináta pontjai a 3.2.a ábrán vannak ábrázolva. A struktúra 5 egyenlő részból épül fel (5 különbözô színnel jelölve az ábrán), amiket

(a)

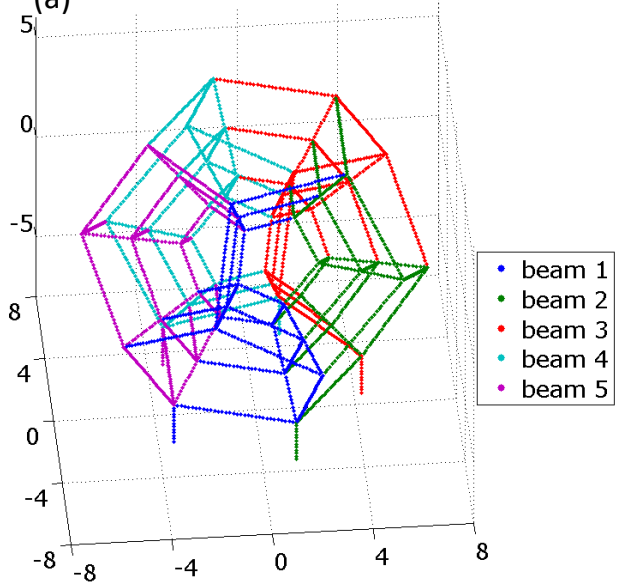

(b)

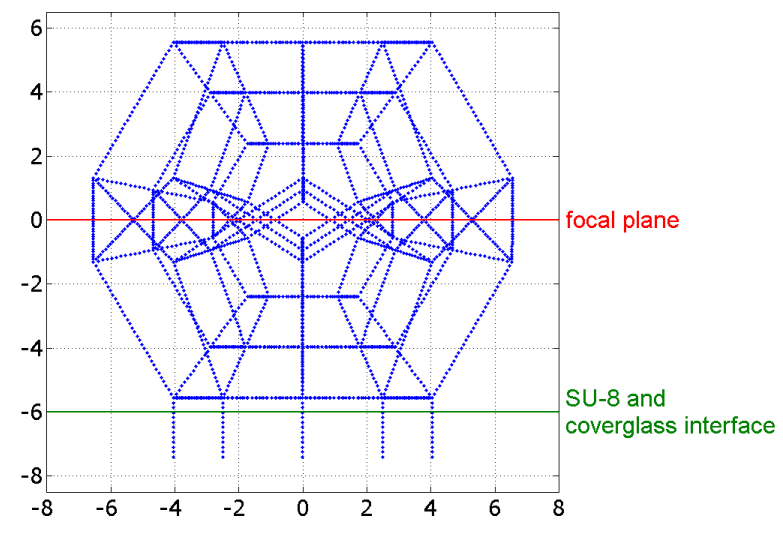

3.2. ábra. a) A teszt mikrostruktúra voxel koordinátáinak három-dimenziós ábrázolása. A Z-koordináták az objektív fókuszsíkjától mértek. A különbözô holografikus nyalábok fókuszai által exponált voxeleket különbözô színek jelölik. b) Y-Z nézetú ábrázolás az objektív fókuszsíkjának és az üveg-SU-8 határfelület pozíciójának bemutatására. A tengely egységek mikrométerben értendőek. 
párhuzamosan 5 darab holografikus fókusz exponál. A fókuszok X és Y koordinátáihoz egy 10 mikrométeres eltolást adtam, hogy a holografikus nyaláb formázás során fellépô nulladik diffrakciós rendtól elválasszam óket, amit így a 3.1 ábrán A-val jelölt apertúrával szelektíven ki lehetett takarni. Mivel egy holografikus lencse diffrakciós hatásfoka a zirányú koordináta abszolút értékével csökken, érdemes volt a mikrostruktúra pontjait a fókuszáló objektív fókuszsíkjához képest z-irányban centrálni. Ennek következtében az objektív fókuszsíkját az SU-8 fotopolimer rétegbe kellett pozicionálni, körülbelül 6 mikrométerrel a hordozó fedólemez felső felületétól (3.2.b ábra).

A mikrostruktúra három egymásba ágyazott, radiálisan összekötött dodekaéderból épült fel, amelyek köré írható gömbök sugarai 3, 5, és 7 mikrométerek voltak. A struktúrát egymástól egyformán 150 nanométerre lévô pontokból felépítve, összesen 2745 voxel exponálása volt szükséges, 549 darab 5 fókuszt létrehozó hologram által. A hologramokat az SLM $60 \mathrm{~Hz}$ frissítési sebességével megjelenítve a teljes struktúra exponálása $9.15 \mathrm{~s}$ alatt történt, ami $9 \mu \mathrm{m} / \mathrm{s}$ pásztázási sebességnek felel meg. A voxelek exponálásának sorrendje megtekinthetô az alábbi videón: [81]. Érdemes megjegyezni, hogy minden hologram ugyanazokkal a véletlenszerúen választott kezdeti $\theta_{m}$ fázisokkal volt számolva (GSW algoritmus 2.10 egyenlet). Ez szükséges volt a holografikus fókuszok intenzitás fluktuációjának minimalizálása érdekében, amely tipikusan fennáll, ha az SLM-en egymást követő hologramok között nagy az átlagos fáziskülönbség [82], ami különösen igaz, ha minden hologram más és más véletlenszerú $\theta_{m}$ kezdeti értékekkel van számolva.

Az IPL fotopolimert használva lehetséges volt a holografikus TPP videóra rögzítése, amelyból 6 személtetô képkockát mutat a 3.3 ábra.
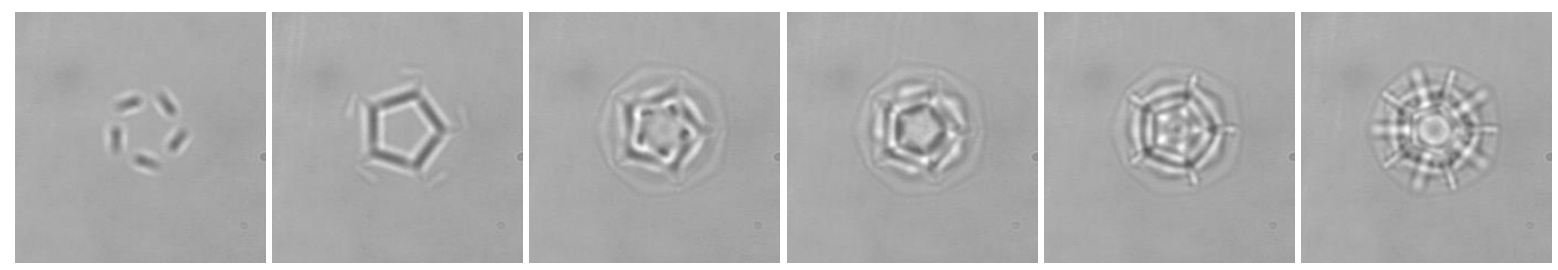

3.3. ábra. A holografikus két-fotonos polimerizáció folyamatának világos látóterư mikroszkópos felvétele IPL fotopolimerben. A videó megtekinthetô az alábbi hivatkozást követve: [83].

Az SU-8-ból polimerizált teszt mikrostruktúra pásztázó elektronmikroszkópos felvételei a 3.4 ábrán láthatóak. A teljes alkalmazott lézerteljesítmény $23 \mathrm{~mW}$ volt az 5 holografikus nyalábra. A fabrikáció minőségének jellemzésére megmértem a mikrostruktúra legkülsố vonal szegmenseinek laterális vastagságait (3.4.b ábrán számokkal jelölve). Az egyes szegmensek átlagos vastagságát a szórásukkal együtt a 3.5 grafikonon ábrázoltam. A 10 szegmens átlagos vastagsága 454 nm, 17.33 nm szórás mellett, ami mindössze 3.8\%-os relatív hiba. Az egyes vonalak vastagságának variációja szintén alacsony, a szórások átlaga 10.12 nm. Ezen mértékek alapján kijelenthetô, hogy az 5 holografikus fókusz intenzitása közel egyenlố volt, valamint az egyes fókuszok intenzitása csak nagyon kis mértékben 
ingadozott a holografikus pásztázás során.
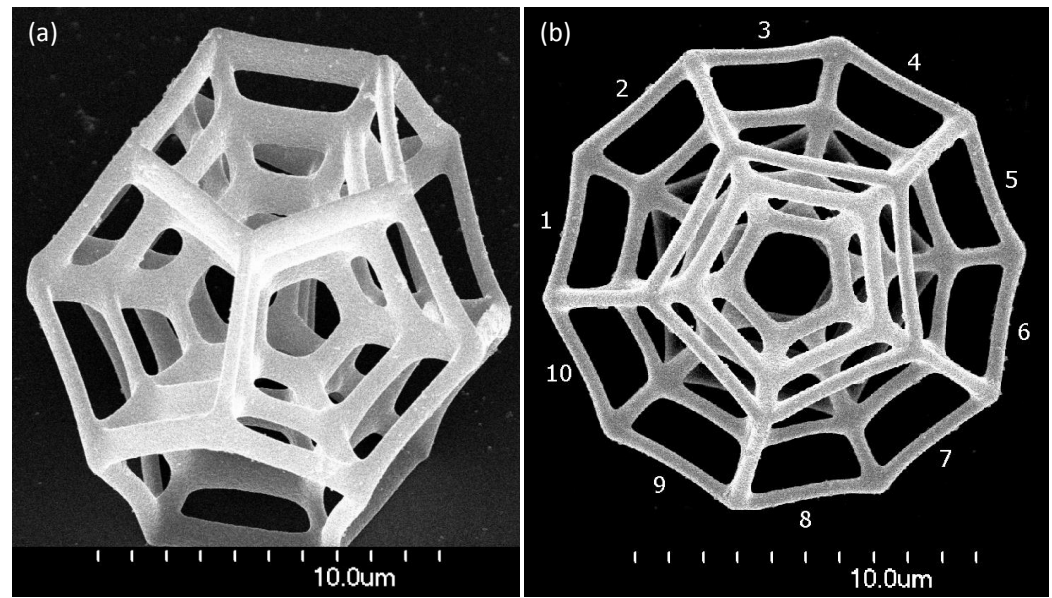

3.4. ábra. Egy holografikusan polimerizált teszt mikrostruktúra pásztázó elektronmikroszkópos képei, 45 fokban döntött (a), illetve felülnézetben (b).

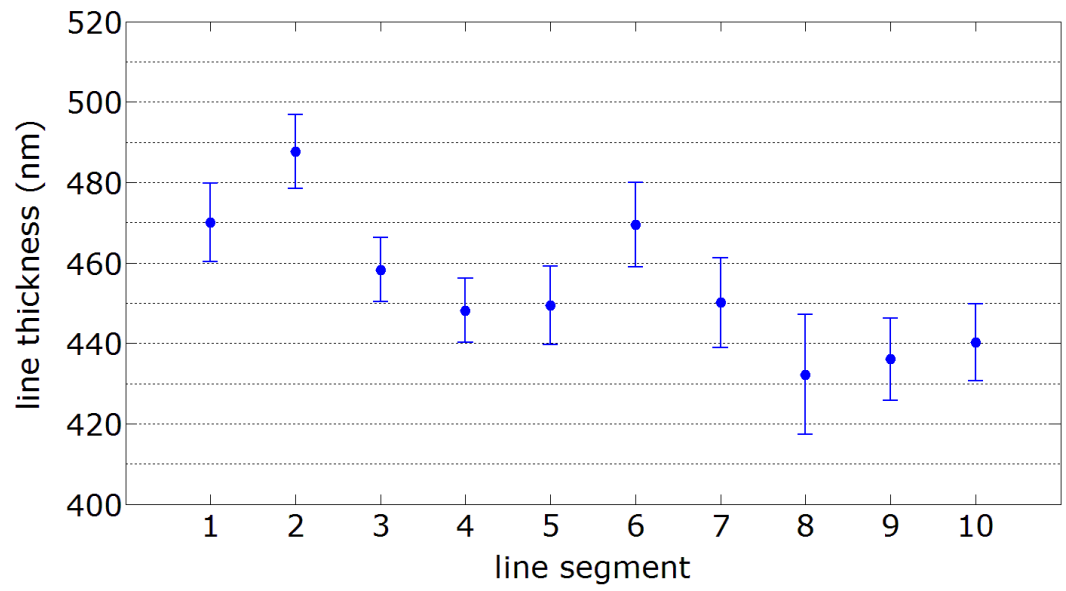

3.5. ábra. A 3.4.b ábrán számokkal jelölt vonal szegmensek átlagos vastagsága és szórása.

\subsubsection{Konklúzió}

Sikeresen demonstráltam, hogy komplex szerkezetú, három-dimenziós mikrostruktúrák két-fotonos polimerizációja felgyorsítható azáltal, hogy az egyes mikrostruktúrák exponálását párhuzamosan több holografikus lézer fókusz végzi, amelyeket egy térbeli fázismodulátor hoz létre a TPP rendszer lézernyalábjának holografikus formázása révén. Az ehhez szükséges hologramok számolása egy CUDA GPU számítási teljesítményét kihasználva a holografikus TPP során valós idôben történt. A holografikus fókuszok intenzitásainak uniformitása, valamint időbeli stabilitása az elkészített teszt mikrostruktúrákon végzett vonalvastagság mérések alapján kiválónak mondható. Az alkalmazott 60 Hz frissítési sebességú SLM-el viszonylag alacsony, $9 \mu \mathrm{m} / \mathrm{s}$ pásztázási sebességet lehetett csak elérni, 
azonban napjainkra már akár $600 \mathrm{~Hz}$ sebességú SLM-ek is rendelkezésre állnak. Így nincs akadálya, hogy a dinamikus holografikus lézernyaláb formázás alkalmazásával, nagy sebességgel pásztázható, többszörös holografikus fókuszokkal megnövelhető legyen a TPP gyártási folyamatának sebessége. 


\subsection{Biológiai sejtek indirekt optikai manipuláción ala- puló többnézetû mikroszkópiája}

\subsubsection{Mikrostruktúra alapú indirekt optikai manipuláció}

Az optikai csipesz feltalálása óta széles körben elterjedt módszerré vált a biológiában. Erôk és elmozdulások nagy precizitású mérésének lehetôsége rendkívül jelentős alkalmazásokra talált a kísérleti biológia területén. Az akár szub-nanométeres pontosságú elmozdulások detektálása [84], valamint az akár femtonewton érzékenységû erômérés [85] biomolekulák korábban nem lehetséges vizsgálatait tette lehetôvé [86-89]. Mikroszkopikus biológiai objektumok fizikai kontaktus nélküli manipulációjának lehetôsége szintén jelentôs kísérleti elônyöket nyújt. A lézercsipesz alkalmasságát élő sejtek térbeli manipulációjára már a fejlesztésének korai szakaszában demonstrálták [90], és azóta is kutatások célpontja [91,92]. Sejtek optikai manipulációjával lehetséges például sejt-patogén kölcsönhatások karakterizálása [93], fagocitózis kontrollált előidézése és megfigyelése [94], valamint úszó baktérium sejtek flagelluma által kifejtett hajtóerô megmérése [95].

A számos alkalmazás ellenére azonban az élő sejtek direkt lézeres csapdázását több probléma is árnyalja. A sejtek optikai inhomogenitása miatt a lézercsipesz által megragadott pont nehezen határozható meg előre, egy sejtnek több lokálisan nagyobb törésmutatójú része is lehet [96]. Emellett a sejtek nagy mérete és alacsony átlagos törésmutatója miatt a csapdázás ereje is gyenge. További probléma, hogy az optikai csapdát alkotó lézerfókusz nagy intenzitása legtöbbször káros a csapdázott sejtre [97-102]. Habár a csapdázó lézer hullámhosszának gondos megválasztásával csökkenthetô a károsodás, a sejtek életbennmaradása mindig kérdéses marad, amit minden kísérletben ellenőrizni kell.
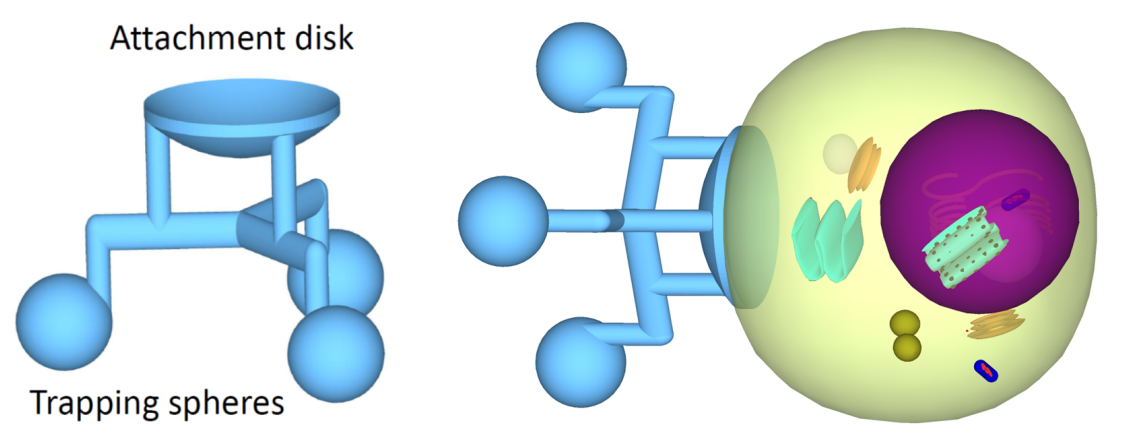

3.6. ábra. Sejtek mikrostruktúra alapú indirekt optikai manipulációjának koncepciója.

A fent leírt problémák elkerülhetőek a sejtek indirekt módon történô optikai csapdázásával, amely esetén a lézercsipesz egy, a sejt felszínéhez kötött köztes objektumot ragad meg. Sejtmembránhoz tapasztott mikrogolyók alkalmazásával jelentősen nagyobb csapda erôvel végezhetô egy sejt optikai manipulációja [103,104], miközben a csapdázó lézer jóval kisebb mértékben éri a sejtet. 
Még további javulás érhetô el polimer mikrostruktúrák alkalmazásával [21]. A kétfotonos polimerizáció módszerével sejtek nagy precizitású három-dimenziós optikai manipulációjához optimális alakú mikromanipulátor struktúrák gyárthatóak. A struktúrán (3.6 ábra) elhelyezett gömbök jól definiált fogáspontokat biztosítanak három darab holografikus optikai csapdának, amelyekkel a mikromanipulátor 6 szabadsági fok mentén mozgatható. A gömbök kis átmerôje ( $4 \mu \mathrm{m})$ és nagy törésmutatója (1.6) nagy csapdaerôt, és következésképpen nagy stabilitású csapdázást tesz lehetővé. A megcélzott sejt a mikrostruktúra egy specifikus részéhez tapasztható, amely a csapdázó fókuszoktól biztonságos távolságban helyezkedik el, így a sejt lézeres roncsolása teljesen elkerülhetó.

A sejtek kötődését a mikromanipulátorhoz biokémiai funkcionalizálás biztosítja, ennek eljárását a csoportunk egykori PhD hallgatója, Badri L. Aekbote dolgozta ki [20]. Az SU-8 fotopolimer anyagból álló mikromanipulátor felülete egy sor kémiai kezelés elvégzésével streptavidin fehérjével vonható be. A streptavidin magas biotin kötô affinitását kihasználva, előzetesen biotinnal bevont sejtek így a mikromanipulátorhoz tapaszthatóak. E módszer publikálása óta tovább fejlődött csoportunk PhD hallgatója, Fekete Tamás munkája révén. A mikromanipulátort borító streptavidin molekulákhoz egy további molekula, biotinált konkanavalin-A kapcsolható, amely képes az emlős sejtek felszínén általánosan jelen lévő glikokalixhoz kötődni. Így, ezzel a továbbfejlesztett funkcionalizálással már nem szükséges a cél sejtek biotinnal történő bevonása.

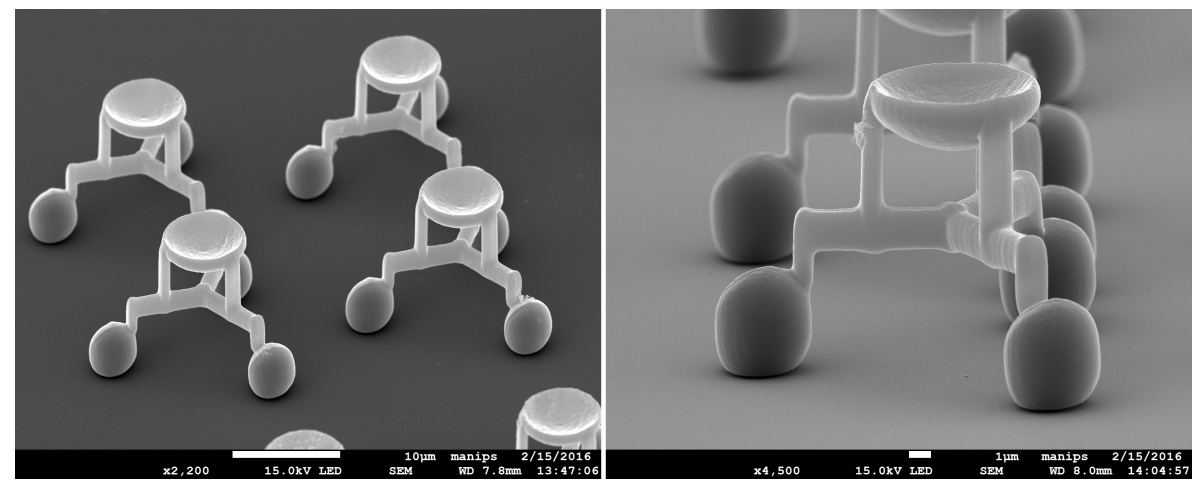

3.7. ábra. Két-fotonos polimerizációval készített mikromanipulátor struktúrák pásztázó elektronmikroszkópos felvételei.

A mikromanipulátor struktúrákat a 3.1.2 fejezetben bemutatott TPP rendszerrel készítettem. A fabrikáció felgyorsítására a rendszerbe épített SLM-mel 4 darab statikus holografikus fókuszt hoztam létre, amelyeket egy három-dimenziós piezo-transzlátor (P124 731.8L and P-721.10, Physik Instrumente GmbH, Németország) pásztázott végig a mikromanipulátor struktúrához tervezett útvonalakon (lásd 2.5. ábra). Az alkalmazott lézerteljesítmény $3 \mathrm{~mW}$ volt fókuszonként, 1 - $32 \mu \mathrm{ms}^{-1}$ pásztázási sebességek mellett. Az elkészített struktúrák pásztázó elektronmikroszkópos felvételei a 3.7 ábrán láthatóak.

A mikromanipulátor struktúrával végzett kísérleteket a következô alfejezetben részletezett, fluoreszcens mikroszkópra épített holografikus optikai csipesz rendszerrel végez- 


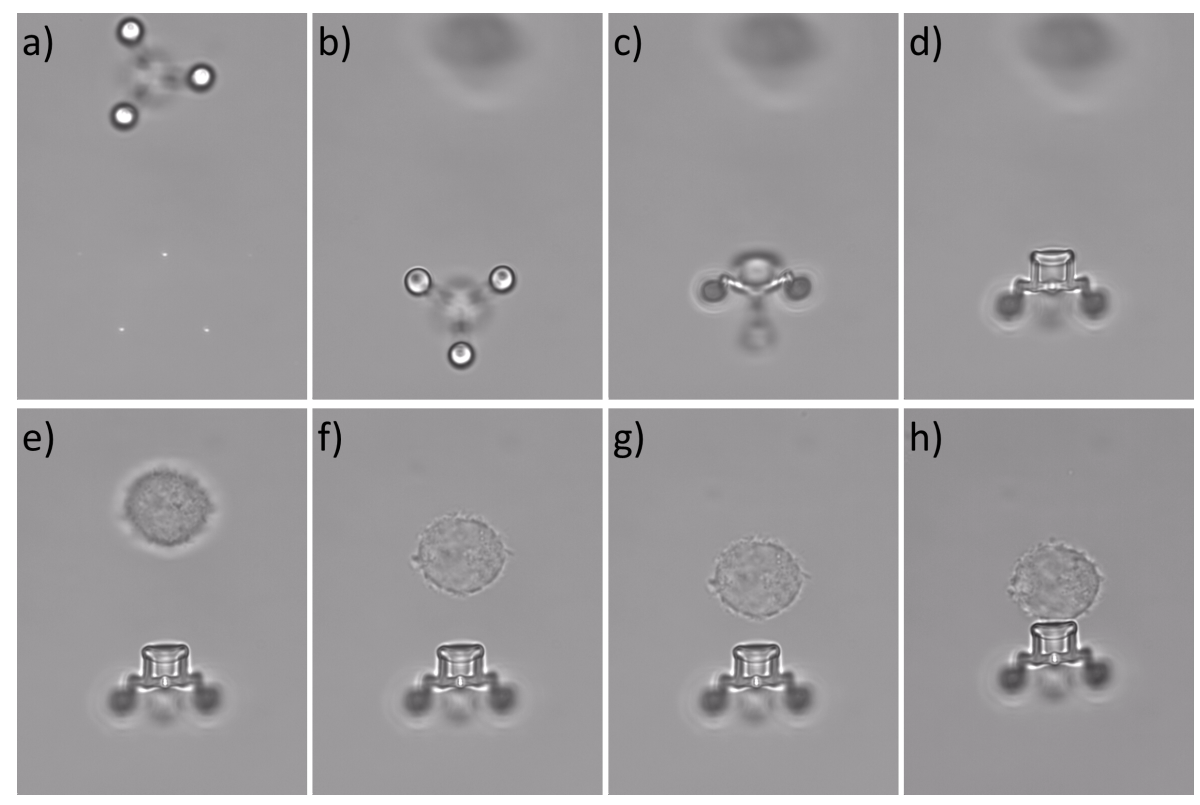

3.8. ábra. Egy K562 sejt hozzátapasztása egy mikromanipulátor struktúrához. a-d: A mikromanipulátor csapdázása és orientálása. e-h: A kiválasztott sejt megközelítése és hozzányomása a mikromanipulátor tányérjához.

tem. A kísérletekhez olyan egyszerû mintákat készítettem, amelyek kettő, egymástól a széleiken kétoldalú ragasztóval elválasztott mikroszkóp fedólemezból álltak (3.13 ábra). A két fedôlemez közti körülbelül 100 um magas térrészbe a sejtek (k562 fehérvérsejt) és a mikromanipulátor struktúrák szuszpenzióját egy mikropipettával juttattam be. Egy mikromanipulátornak egy sejthez történő hozzátapasztásának folyamatát a 3.8 ábra mutatja be. A mintatér alsó üveglemezére lesüllyedt struktúra képe és az alkalmazott három darab holografikus optikai csapda reflexiója a 3.8.a ábrán látható. A holografikus csapdákkal megfogott mikromanipulátort először a csapdák mozgatásával 90 fokkal el kell fordítani (3.8.b-d ábra). Az így orientált manipulátor ezután megfelelő magasságba pozicionálva a megcélzott sejt közepéhez oldalról hozzányomható (3.8.e-h ábra).

A mikromanipulátor, illetve a hozzátapasztott sejt a mintán belül tetszóleges helyre vihetô a mikroszkóp motorizált mintatartó asztalával, valamint a csapdázó lézert fókuszáló mikroszkóp objektív fókuszsíkjának pozicionálásával. Ezenfelül, a látómezôn belül a holografikus csapdák mozgatásával nagy precizitású három-dimenziós pozicionálás és forgatás lehetséges (3.9 és 3.10 ábra) [105].

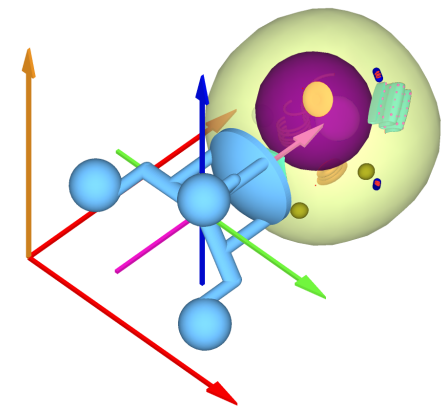

3.9. ábra. A mikromanipulátor 6 szabadsági fokos mozgatásának tengelyei. A megfigyelés képsíkjába esô laterális transzlációs tengelyeket piros szín jelöli, a rájuk meróleges, az optikai tengellyel párhuzamos transzlációs tengelyt pedig narancssárga. A kék, zöld, illetve rózsaszín nyilak a mikromanipulátorhoz kötött forgástengelyeket jelölik. 


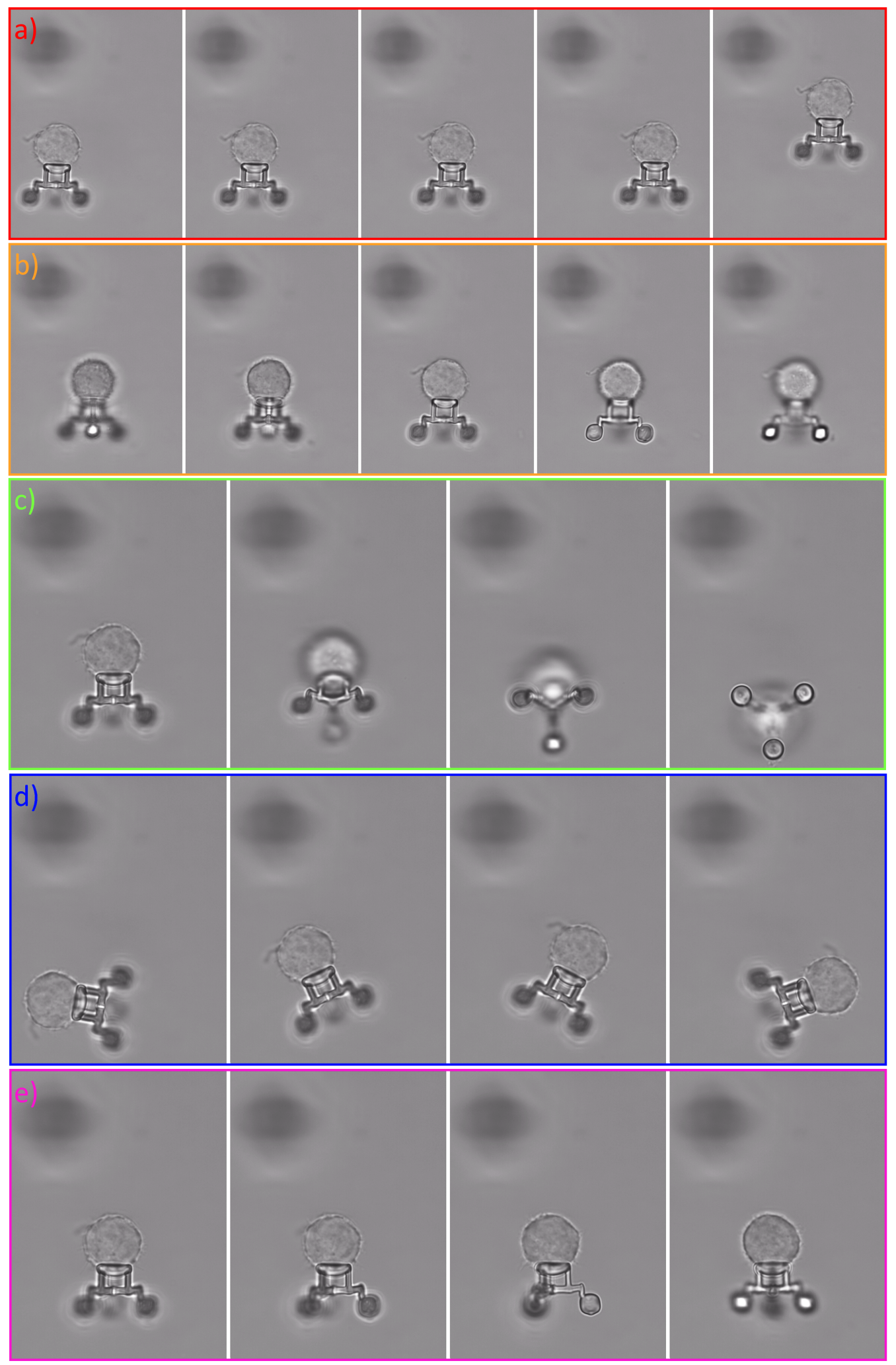

3.10. ábra. Egy mikromanipulátorral indirekt csapdázott sejt 6 szabadsági fokú térbeli manipulációja a holografikus optikai csapdák mozgatásán keresztül. Transzláció a képsíkban laterálisan (a), illetve függólegesen az optikai tengely irányában (b). Forgatások a mikromanipulátorhoz kötött forgástengelyek körül (c-e). Az egyes panelek színei a 3.9 ábrán látható transzlációs és forgatási tengelyeknek felelnek meg. 
Habár a mikromanipulátor struktúrával nagy csapdaerókkel végezhető az optikai mikromanipuláció, a struktúra és a hozzákapcsolt sejt a Brown-mozgásuk miatt elkerülhetetlenül fluktuál a holografikus csapdák optikai potenciáljain belül. A csapdázás stabilitásának meghatározásához kiértékeltem egy mikromanipulátorral tartott sejt mozgását. Ehhez rögzítettem 2000 darab, 1 ms expozíciós idejû világos látóterú mikroszkópos képet. A felvett képsorozaton a sejt laterális elmozdulásait egy MATLAB-ban írt rutinnal határoztam meg, felhasználva a MATLAB Computer Vision Toolbox-ában található módszereket (pl.: detectSURFFeatures). Geometriai okokból a pozíció-fluktuáció a sejtnek a holografikus csapdáktól legtávolabb eső pontjaira a legnagyobb. A kiértékelés eredményéből ezért egy ilyen, a három csapdázó fókusz síkjától 25 um-re levô pontot mutatok be (3.11 ábra), amely felsô határt ad a pozíció instabilitás mértékére. A kiválasztott pont pozíció szórása a 3.11.a ábrán látható. A pozíció fluktuáció a mikromanipulátor szimmetria tengelyének irányában (X) 90 nm, arra merôlegesen (Y) pedig 150 nm félértékszélességú eloszlást mutat (3.11.b ábra).
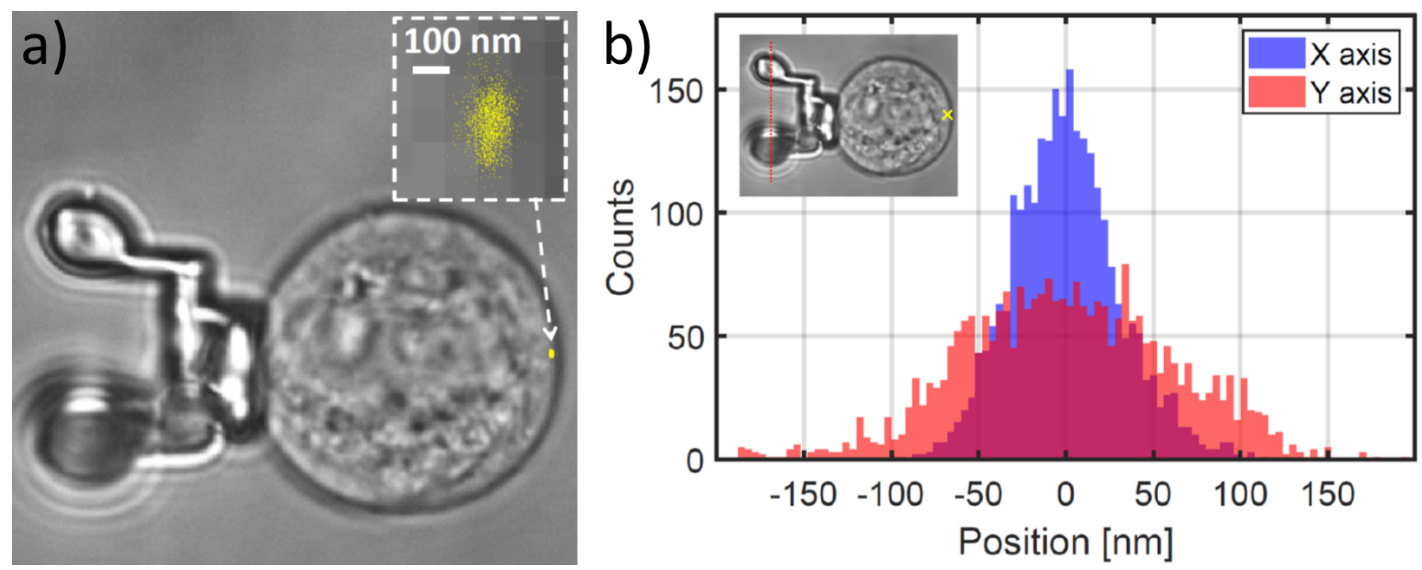

3.11. ábra. Egy mikromanipulátorral tartott sejt laterális pozíció fluktuációja. a) A sejtról rögzített világos látóterú mikroszkópos kép, és egy kiválasztott pontjának pozíció szórása. b) Az X és Y irányú pozíció eloszlások. A kiválasztott pont körülbelül 25 m-re van a három csapdázó fókusz síkjától (piros szaggatott vonal az inzert képen).

A fenti eredmények alapján látható, hogy a két-fotonos polimerizáció módszerével készített mikromanipulátor struktúrával sikeresen kiterjeszthetô a holografikus optikai csipesz alkalmazása sejtek nagy stabilitású, 6 szabadsági fokú térbeli manipulációjára. A manipulált sejt tetszôleges orientációkba állítható és a mikroszkópos megfigyelés síkjához képest is szabadon pozicionálható (3.10.b ábra), ami nagyfokú szabadságot biztosít a sejtrôl történő képalkotáshoz. A csapdázott mikromanipulátor laterális pozíció stabilitása megfelelő mértékû, hogy ne okozzon jelentôs elmosódást hosszabb expozíciós idejû́ (pl. fluoreszcens) képfelvételek készítése esetén sem. 


\subsubsection{Fluoreszcens mikroszkópra épített Holografikus Optikai Csi- pesz}

A mikromanipulátor struktúrával végzett sejtes kísérleteket egy Nikon Eclipse Ti-U invertált fluoreszcens mikroszkóphoz hozzáépített holografikus optikai csipesszel végeztem. Az alábbiakban bemutatom ezt az általam tervezett és megépített rendszert, kitérve annak optikai felépítésére, valamint a holografikus lézercsipeszt vezérlő szoftverre.

A Nikon Eclipse Ti-U mikroszkóp nagy előnye, hogy a végtelenre korrigált optikáját kihasználva lehetôvé teszi egy második szưrôtartó revolver beépítését az eredeti fölé (3.12 ábra). Így a mikroszkóp fluoreszcens képalkotó rendszere mellé zavartalanul beilleszthető a holografikus lézercsipesz nyalábjait a mikroszkópba

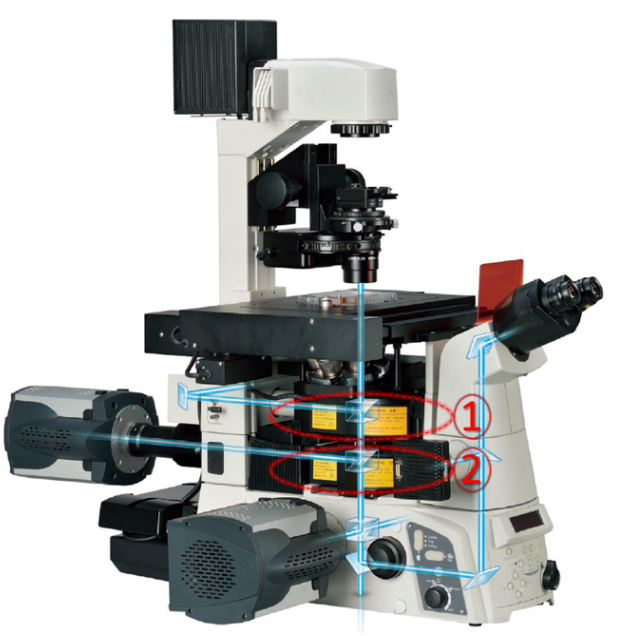

3.12. ábra. Nikon Eclipse Ti-U invertált fluoreszcens mikroszkóp. A két darab egymás felett elhelyezkedô szứrôtartó revolver piros színnel ki van emelve. csatoló dikroikus tükör.

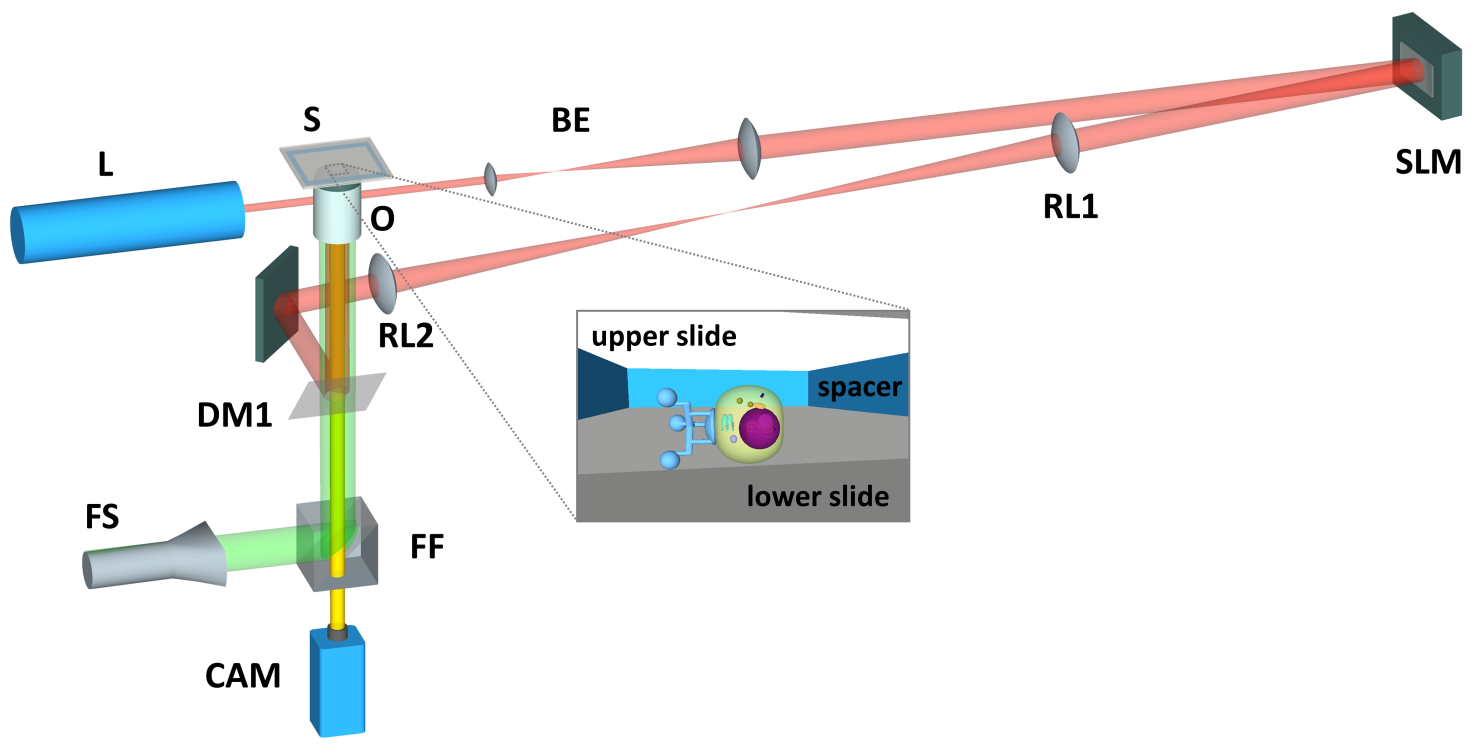

3.13. ábra. Nikon Eclipse Ti-U invertált fluoreszcens mikroszkópra épített holografikus optikai csipesz sematikus optikai elrendezése. Az inzert kép a kettô mikroszkóp fedólemezból álló minta belsejét mutatja.

A holografikus optikai csipesz felépítésének sematikus rajza a 3.13 ábrán látható. A rendszer lézerforrása egy $1064 \mathrm{~nm}$ hullámhosszú, $10 \mathrm{~W}$ teljesítményú infravörös lézer (L)

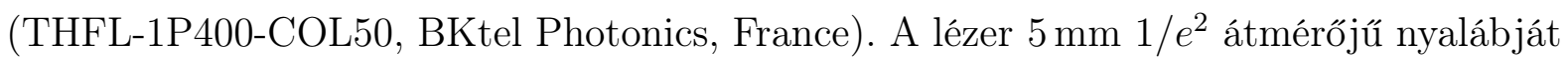
egy akromatikus dublett lencsékből ( $\mathrm{f}=35 \mathrm{~mm}$ és $250 \mathrm{~mm}$ ) álló nyalábtágító (BE) kitágít- 
ja, hogy annak csúcsintenzitása ne haladja meg a rendszerbe épített térbeli fázismodulátor (SLM) (PLUTO NIR, Holoeye, Germany) $2 \mathrm{~W} \mathrm{~cm}^{-2}$-es toleranciáját. Az SLM-ról visszavert holografikusan formázott nyalábot egy 4f lencse rendszer (RL1, RL2, f = $400 \mathrm{~mm}$ ) konjugálja a mikroszkópon elhelyezett objektív (O) hátsó fókuszsíkjába. A lézercsipesz rendszerekben gyakran alkalmaznak nagyon magas (1.4) numerikus apertúrájú, olaj immerziós mikroszkóp objektíveket a lehetô legnagyobb csapda erók elérésére [106]. Az ilyen objektívekkel azonban nem lehet vizes mintákban mélyre fókuszálni, csak a mintát határoló üveg felület közelében lehetséges a csapdázás, beljebb fókuszálva az üveg (olaj) és a víz közötti törésmutató különbség miatt fellépô szférikus aberráció eltorzítja a csapdázó fókuszt. Ennek fényében egy víz immerziós objektív alkalmazása mellett döntöttünk (60x, NA=1.2, Olympus UPlanApo/IR), amellyel az optikai csapdázás és a képalkotás is zavartalanul végezhető akár $100 \mu \mathrm{m}$ mélyen is a vizes mintákban (S). Az objektív körülbelül $7 \mathrm{~mm}$ átmérôjú hátsó apertúráját a kitágított lézernyaláb közel uniform intenzitással tölti ki, ami előnyös az optikai csapdák axiális irányú csapdaereje szempontjából. A lézercsipesz nyalábja az egyik hátsó porton keresztül lép be a mikroszkópba, ami után a felső szưrőtartóba (3.12. ábrán 1-essel jelölve) helyezett aluláteresztő dikroikus tükör (DM1, $850 \mathrm{~nm}$ ) által a fókuszáló objektív tengelyébe csatolódik. A mikroszkóp alsó szúrőtartójába tetszőleges fluoreszcens szűrőkockák (FF) helyezhetőek el, a lézercsipesz és a fluoreszcens képalkotás párhuzamosan múködtethető. A fluoreszcens képalkotáshoz egy fémhalogénlámpa (Lumen 200S, Prior Scientific, Inc., USA) biztosítja a gerjesztő fényt, a képek rögzítése egy EMCCD kamerával (Rolera EMC ${ }^{2}$, Qimaging, Kanada) végezhetô. Ezenfelül a mikroszkóp egy gyors képrögzítésre képes kamerával is fel van szerelve (GS3-U3-23S6M, Point Grey Research Inc., Kanada), amely 1920x1080 felbontás mellett 160 kép/másodpercre képes. A minták (S) laterális mozgatása egy motorizált mikroszkóp asztallal végezhető (Prior Scientific, Inc., USA).

\section{Vezérlő szoftver}

A holografikus optikai csipesz rendszer hatékony és könnyen elsajátítható múködtetéséhez egy grafikus kezelő felülettel ellátott szoftvert készítettem. A programot C++ nyelven írtam, felhasználva a FreeGLUT [79] és az AntTweakBar [107] programkönyvtárakat a program OpenGL ablakának és grafikus felületének létrehozására (3.14. ábra). A szoftverrel tetszóleges térbeli konfigurációban elrendezett holografikus optikai csapdák hozhatóak létre, amelyek kezdeti koordinátáit a program az indításakor egy fájlból olvassa be, amelyben egymástól függetlenül irányítható csapda csoportok is definiálhatóak. A grafikus felületen kék színú golyók reprezentálják az egyes optikai csapdákat, a 3.14 ábrán egy sejtmanipulátor struktúra megfogásához szükséges három optikai csapda és a hozzájuk tartozó hologram látható. Az optikai csapdák csoportjai 6 szabadsági fokkal mozgathatóak a grafikus felület vezérlő elemeivel, illetve a billentyúzet egyes gombjaival. 
A csapdák forgatása esetén kiválasztható, hogy a csoporthoz kötött (lásd 3.9 ábra), vagy egy fix külsố koordináta rendszer tengelyei körül történjen. Ezenfelül a csapdák elrendezései skálázhatóak is az egyes koordináta tengelyek mentén, valamint uniform módon minden irányban is. A program alkalmazását demonstráló videó megtekinthetô az alábbi hivatkozást követve: [108].

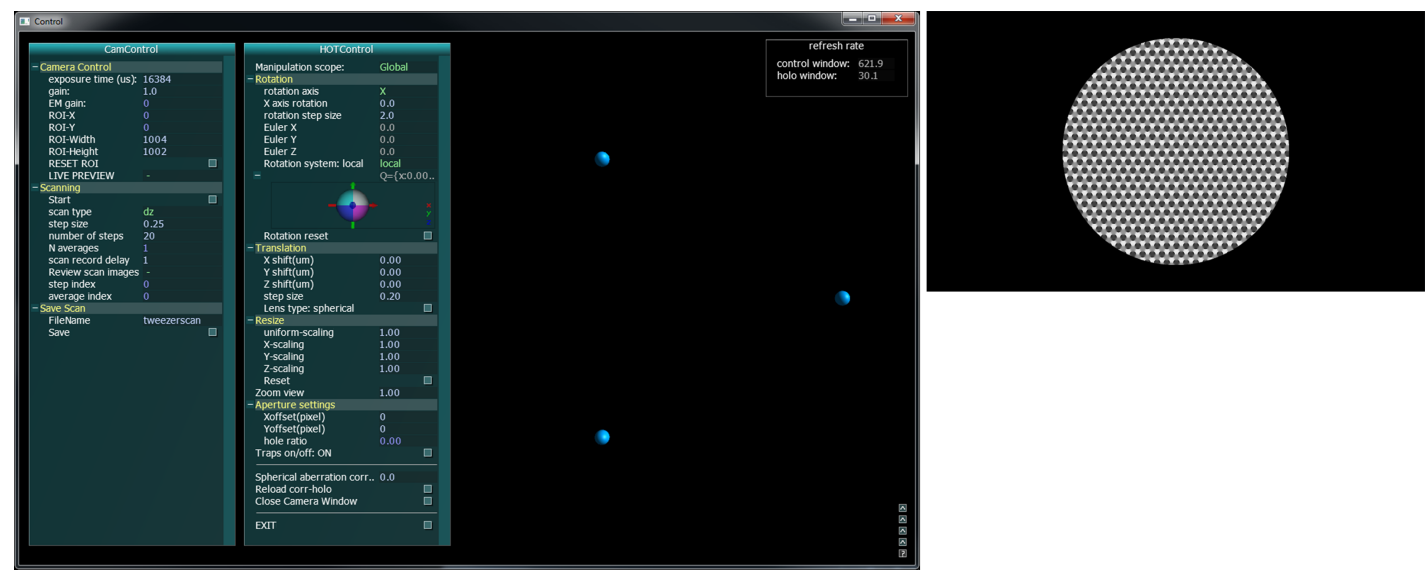

3.14. ábra. A holografikus optikai csipeszt vezérlő szoftver grafikus felülete, valamint az SLM-et vezérlő hologramot megjelenítô ablak képernyőfotója.

A holografikus csapdákat létrehozó hologramok számolására a 2.3.2 alfejezetben bemutatott súlyozott Gerchberg-Saxton (GSW) algoritmust alkalmaztam. Annak érdekében, hogy a holografikus csapdákat a kezelô felülettel valós idóben lehessen mozgatni, a GSW hologram számolás felgyorsítására a holografikus TPP (3.1 alfejezet) módszerénél már bemutatott GPU alapú számítást alkalmaztam.

A fent felsorolt funkciókon felül a holografikus csipeszt vezérlő programot alkalmassá tettem olyan mérések elvégzésére, ahol az optikai csapdák mozgatásával szinkronban rögzíthetô a rendszer EMCCD kamerájának képe. Az ilyen mérések beállításai a 3.14 ábrán látható bal oldali panelen adhatóak meg. Beállíthatóak az EMCCD kamera különböző paraméterei, valamint az, hogy az optikai csapdák milyen irányba, mekkora lépésekben és hányszor mozduljanak a mérés során. A program ezen funkcióját kihasználva a sejtmanipulátor struktúrával mozgatott sejtekrôl fluoreszcens z-stack képsorozatok rögzíthetőek.

\section{Hullámfront korrekció mérése}

A holografikus lézercsipesz rendszert megépítése után először mikrogolyók (3 $\mu \mathrm{m}$ átmérô) csapdázásával teszteltem. Laterálisan elhelyezkedő holografikus csapdákkal egyszerre több mikrogolyót gond nélkül lehetett csapdázni, viszont feltűnt, hogy ha egymás fölé pozicionáltam kettő holografikus csapdát, akkor a felsô csapdából kilökődött a mikrogolyó felfelé, a fényterjedés irányába. Emellett, a mikromanipulátor struktúrák is gyakran kilökődtek az optikai csapdákból ha a 3.8.b-d ábrán látható módon oldalra próbáltam ôket fordítani. E kísérleti tapasztalatok arra utaltak, hogy az optikai csapdák nem optimáli- 
sak, különösen az optikai tengely irányába esô, z-irányú csapdaerố gyenge. Ennek tipikus oka lehet az optikai csapdákat alkotó fókuszoknak az ideálistól eltéró alakja. Az általunk alkalmazott lézer nyalábja megfelelô minőségú a diffrakció limitált fókuszáláshoz, azonban amíg végighalad a lézercsipesz optikai rendszerén, hullámfrontja eltorzulhat. Habár a lézercsipesz rendszert jó minőségû $(\lambda / 5-\lambda / 10)$ optikai elemekból építettem, korábbi tapasztalataink [14] alapján az SLM okozhat nagy mértékú hullámfront torzulást, továbbá a mikroszkópba 1 mm-nél vastagabb dikroikus tükröt (DM1) nem lehetett elhelyezni, aminek pedig a vékonysága miatt gyaníthatóan nem megfelelően sík a tükröző felülete.

A holografikus csipesz SLM-je szerencsére alkalmazható a csapdázó lézernyaláb hullámfront torzulásának kompenzálására, azonban ehhez szükséges a hullámfront alakjának megmérése. A hullámfront torzulás megmérésére a Tomaŝ Ĉiẑmar és munkatársai által közölt módszert alkalmaztam [60]. A módszer alapja a csapdázó lézernyaláb felosztása laterális részekre, módusokra, amelyek közötti fáziskülönbség megállapítható a páronként megfigyelt interferenciájukból. Egy módust referenciaként rögzítve, a többivel pedig végigpásztázva a lézernyaláb keresztmetszetét a teljes hullámfront alakja megmérhetô. Az SLM-et felhasználva ez könnyen megvalósítható, egy holografikus rács hologram maszkolásával a csapdázó lézernyalábból tetszóleges részek (módusok) vághatóak ki. Amennyiben a módusok interferenciáját a fókuszáló objektív fókuszsíkjában figyeljük meg, a teljes optikai rendszer által okozott torzulás megmérhetô, annak inverzével korrigálva a nyalábot elérhetô a tökéletes fókuszálás.

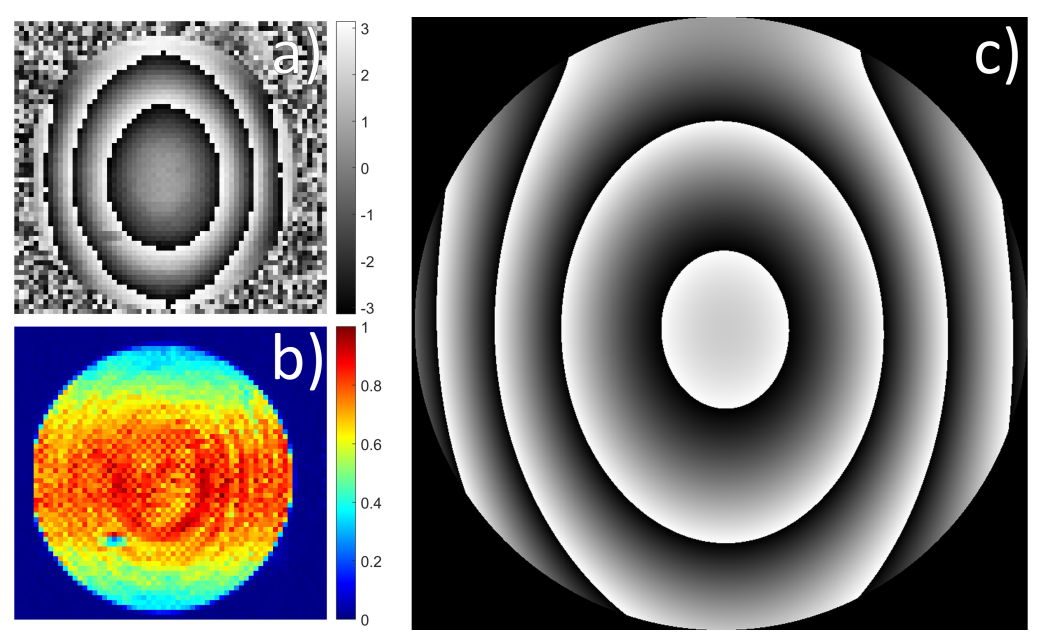

3.15. ábra. A hullámfront torzulás mérés eredménye. a) Az egyes módusok fázisai által kirajzolt hullámfront alak. b) Az egyes módusok normalizált amplitúdói, amiból kirajzolódik az objektív hátsó apertúrájának határa. c) Az illesztett Zernike polinomok alapján, az SLM felbontásához illeszkedő méretben kiszámolt korrekciós hologram.

A mérés elvégzésére egy C++ szoftvert írtam, amely vezérelte a módusok létrehozását az SLM-en megjelenített hologramokkal, és közben szinkronban rögzítette egy megfigyelő kamera képét. Ĉiẑmar és munkatársai méréseikhez egy, a fókuszsíkban elhelyezkedő, 
fluoreszcens nanogolyót használtak pontszerú intenzitás próbának. A mi esetünkben a lézercsipesz infravörös hullámhossza miatt azonban fluoreszcencia nem alkalmazható, ezért én egy mikroszkóp fedôlemezre párolt $150 \mathrm{~nm}$ vastag arany rétegbe maszkolt $300 \mathrm{~nm}$ átmérôjû lyukat alkalmaztam. Ezen a hullámhossz alatti méretû lyukon átszóródó fény intenzitását rögzítette a megfigyelő kamera a mérések során. Ezt, a detektálás módját érintố részletet leszámítva a hullámfront mérést a Ciiẑmar és munkatársai által leírt módon valósítottam meg.

A méréseim során az SLM-en 15x15 pixel méretû módusokat alkalmaztam, ami a mért hullámfront körülbelül 2400 pontból álló felbontását tette lehetôvé. A mérésből kapott adatok kiértékelését MATLAB-ban végeztem el, aminek eredménye a 3.15 ábrán látható. A kapott hullámfrontot (3.15.a ábra) Zernike polinomokkal illesztettem meg, ami alapján a szükséges korrekciós hologram az SLM-hez megfelelő felbontásában szintetizálható (3.15.c ábra). Az első 21 Zernike polinomot figyelembe vevő illesztés eredménye alapján az asztigmatizmus és a szférikus aberráció a domináns optikai aberráció a lézercsipesz rendszerünkben, ami a hullámfront szabályosan torzult alakjából is látható. A nagy mértékú asztigmatizmus és szférikus aberráció konzisztens a megfigyelt, axiálisan gyenge optikai csapdákkal.

A csapdázó lézer hullámfront torzulását korrigáló hologram alkalmazásával már lehetôvé vált mikrogolyók stabil, egymáshoz közeli három-dimenziós csapdázása [108], valamint a mikromanipulátor struktúrák korábban bemutatott 6 szabadsági fokú manipulációja is ezután vált lehetôvé (3.10 ábra).

\subsubsection{Multiview mikroszkópia}

A fénymikroszkópos képalkotást tipikusan anizotrop felbontás jellemzi: még egy nagy numerikus apertúrájú mikroszkóp objektív alkalmazása esetén is az optikai tengely irányában legalább háromszor rosszabb a felbontás, mint arra merólegesen. Ez a fény hullámtermészetéból eredô, sokszor nem kívánt axiális felbontás határ megkerülhető olyan fejlett mikroszkópos technikákkal mint például a stimulált emisszióval történő legerjesztésen alapuló STED mikroszkóp három-dimenziós formája [109], vagy a 4Pi mikroszkópia [110]. Az alacsony axiális irányú felbontás kiküszöbölhető az úgynevezett Multiview mikroszkópia módszerével is [111]. A módszer alapja az, hogy egy mintáról különbözô irányokból felvett három-dimenziós képsorozatokat számítógépes feldolgozással össze lehet kombinálni egyetlen izotrop felbontású képsorozattá. A módszer kulcseleme a mikroszkópos minta különbözô irányokból lehetséges megfigyelésének megvalósítása, amit a minta mechanikus forgatásával [111,112], vagy több megfigyelő objektív alkalmazásával [113,114] érnek el. Az általunk kifejlesztett mikrostruktúra alapú indirekt optikai manipulációval ez szintén megvalósítható, ennek koncepciója a 3.16 ábrán látható. Egy mikromanipulátor struktúrához tapasztott sejtrôl három-dimenziós fluoreszcens képsorozat rögzíthetô a holografi- 
kus csapdák z-irányú mozgatásával. Egy képsorozat felvétele után a sejt visszavihetố a kezdeti pozícióba, majd egy új orientációba való forgatás után egy újabb képsorozat vehető fel. Ezt a sémát ismételve egyes sejtekről tetszóleges számú egyedi nézetú képsorozat rögzíthetô.

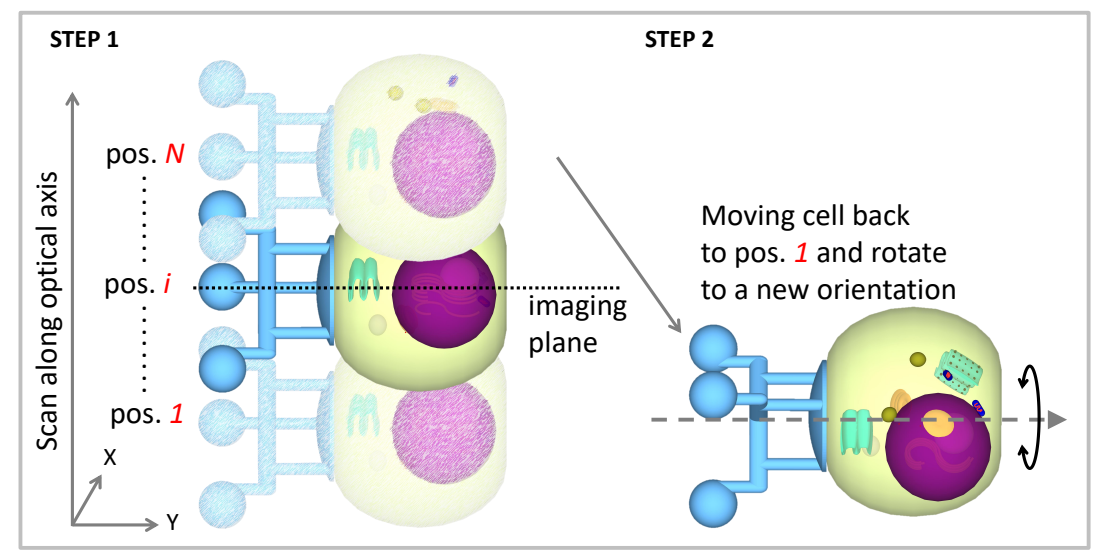

3.16. ábra. A mikromanipulátor struktúra alapú indirekt optikai manipuláció alkalmazásának sémája egy sejt multiview mikroszkópiájára. A sejt N darab diszkrét lépésben átvihetô a megfigyelés síkján az optikai csapdák holografikus mozgatásával, így felvehetô róla egy N darab képból álló fluoreszcens képsorozat (STEP1). Visszatérve a kiindulási pozícióba és a sejtet egy új orientációba forgatva (STEP2) elindítható egy újabb nézetú képsorozat felvétele.

A továbbiakban bemutatom az elóbbiekben ismertetett módon megvalósított multiview mikroszkópiával elért eredményeimet. A méréseket a 3.2.2 alfejezetben bemutatott rendszerrel végeztem, fixált K562 fehérvérsejteken epifluoreszcens képalkotást végezve. Az elérhetô axiális felbontás növekedést sejthez tapasztott fluoreszcens mikrogolyók felvételei alapján kvantifikáltam. A felhasznált K562 fehérvérsejtek fluoreszcensen jelölt mitokondriumjairól kapott felvételek alapján demonstrálom, hogy a módszerünk alkalmas biológiai objektumok közel izotrop felbontású három-dimenziós rekonstrukciójára.

\section{Módszerek}

Az epifluoreszcens képalkotás során a mikrogolyók (CAFR100NM, Magsphere Inc., USA) esetén a 49008-as (gerj.: 560/40 nm, em.: 630/70 nm), illetve a festett mitokondriumokhoz (Mitotracker Deep Red, Thermo Fisher Scientific) a 49006-os (gerj. : 620/50 nm, em.: 700/70 nm) számú szưrôkészleteket használtam (Chroma Technology Corp.). A képsorozatok felvétele során a holografikus csapdák 250 nm-es lépésekben mozgatták a sejtet az optikai tengely mentén. Minden lépésben három darab 100-120 ms expozíciós idejú felvételt készített a lézercsipesz vezérlő programja a rendszer EMCCD kamerájával, amelyeket az adatfeldolgozás során átlagoltam, zajcsökkentés céljából. Egy tipikus sejt esetén egy körülbelül 20 um-es axiális tartomány felvétele volt szükséges (80 darab lépés).

A képsorozatok feldolgozását az irodalomban leírt módszerek alapján [111, 114,115] 
MATLAB-ban írt rutinokkal végeztem. Ennek három fó lépése volt: i) a felvételek dekonvolúciója; ii) a különbözô nézetből felvett képsorozatok térben egymáshoz igazítása, regisztrálása; iii) az egymáshoz igazított felvételek fuzionálása egyetlen három-dimenziós képsorozattá. A feldolgozást egy NVIDIA Titan XP GPU-val felszerelt asztali számítógépen végeztem, kihasználva a MATLAB beépített támogatását a CUDA GPU alapú számításra.

i) A fluoreszcens képsorozatok dekonvolúcióját standard módon alkalmazzák a képek minőségének növelésére. Ez különösen fontos az epifluoreszcens képalkotás esetén, ahol a három-dimenziós képsorozatok szeletei a fókuszsíkon kívülrôl érkező fluoreszcencia miatt tipikusan erôs háttérrel bírnak. A dekonvolúcióra a MATLAB beépített Richardson-Lucy iteratív módszerét használtam. A dekonvolúcióhoz szükséges még az optikai rendszer képalkotását leíró pont-kiszélesedési függvény (point spread function, PSF) ismerete. Ennek megméréséhez egy mikroszkóp fedólemezre párolt arany rétegbe mart nano-lyukat használtam (200 nm vastag réteg, 100 nm lyuk átmérô, fókuszált ion nyalábos marás). A reflektív arany réteget a mikroszkóp objektívvel ellentétes oldalról fehér fénnyel megvilágítva, a nano-lyukon átszóródó fény pontforrásként használható a PSF megmérésre. Az egyes fluoreszcens szűrőkhöz tartozó PSF három-dimenziós alakját az objektív axiális mozgatása mellett rögzített képsorozatokként vettem fel.

ii) A dekonvolvált képsorozatok térbeli regisztrációjára egy korreláción alapuló keresố algoritmust írtam. Habár egy mérési sorozatban az egyes nézetek közötti elforgatások szögei ismertek, az egyes képsorozatok tényleges orientációjában eltérések lehetnek például a mikromanipulátor struktúra alakjának tökéletlensége, deformációja, vagy a sejt nem tökéletesen merev kapcsolódása miatt. Az összeillesztés során a mérések első képsorozatát alkalmaztam referenciának, a többi képsorozatot pedig először a referenciához képesti elforgatásuk szögével transzformáltam a mérésekben alkalmazottnak megfelelő forgástengely körül. A precíz összeillesztésre írt keresố algoritmus célja, hogy megtalálja azt az elforgatást és transzlációt, ami maximalizálja a referencia és az adott képsorozat közötti korreláció értékét. Ehhez kezdetben az algoritmus egy félgömb térrészben 45 fokonként elosztott forgástengelyeket próbált végig. Minden tengely körül egy $\pm 15^{\circ}$ tartományon $1^{\circ}$ lépésekben elforgatta a regisztrálandó képsorozatot és minden forgatásra meghatározta a maximális korrelációt adó transzlációt [116]. Ezt követően az algoritmus a legjobb korrelációt adó tengely és a szomszédai közötti tartományon új forgástengelyeket definiál, amelyeket ismét végigpróbál az előbb leírt módon. Ezt a sémát követve az algoritmus tipikusan 10 iteráció alatt konvergált a maximális korrelációt adó transzformációhoz. A képsorozatok numerikus forgatási transzformációjához a MATLAB interp3 függvényét alkalmaztam.

iii) Az egymáshoz regisztrált képsorozatok fuzionálására két módszert alkalmaztam: egy egyszerú átlagolást, illetve egy frekvenciatérbeli súlyozott összeadást [115]. Átlagolás esetén a fuzionált képsorozat az egyes képsorozatok pixelenkénti átlagaként állt elő. A 
frekvenciatérbeli súlyozott összeadást az alábbi egyenlet írja le:

$$
I_{f}=\sum_{j=1}^{N}\left(w_{j} \cdot I_{j}\right)
$$

ahol $N$ a képsorozatok száma, $I_{j}$ a j-edik képsorozat Fourier transzformáltja, a $w_{j}$ pedig az alábbi egyenlettel számolt súly:

$$
w_{j}=\frac{\sqrt{\left|I_{j}\right|}}{\sum_{i=1}^{N} \sqrt{\left|I_{i}\right|}}
$$

A számolás végén a fuzionált képsorozat a frekvenciatérbeli $I_{f}$ inverz Fourier transzformációjával kapható meg.

\section{Axiális irányú felbontás javulás}

Az axiális irányú felbontás javulás kvantifikációjára olyan sejtekről készítettem felvételeket, amelyek felszínére $100 \mathrm{~nm}$ átmérôjű fluoreszcens golyókat tapasztottunk. Összesen 9 darab képsorozatot készítettem, a 0-180 fokos tartományon 22.5 fokonként elosztott orientációkban. A mikroszkópiában a fluoreszcens képsorozatok iteratív dekonvolúciója során az elvégzett iterációk száma egy szubjektív paraméter, nagy számú iteráció elvégzésével egy mikrogolyó képe például tetszólegesen apróra zsugorítható. A dekonvolúciós folyamat jellemzésére ezért megvizsgáltam, hogy az iteráció előrehaladtával hogyan változik a mikrogolyók képeinek laterális szélessége (3.17.a ábra), illetve, hogy lépésról lépésre mekkora a relatív változás a képsorozaton (3.17.b ábra).
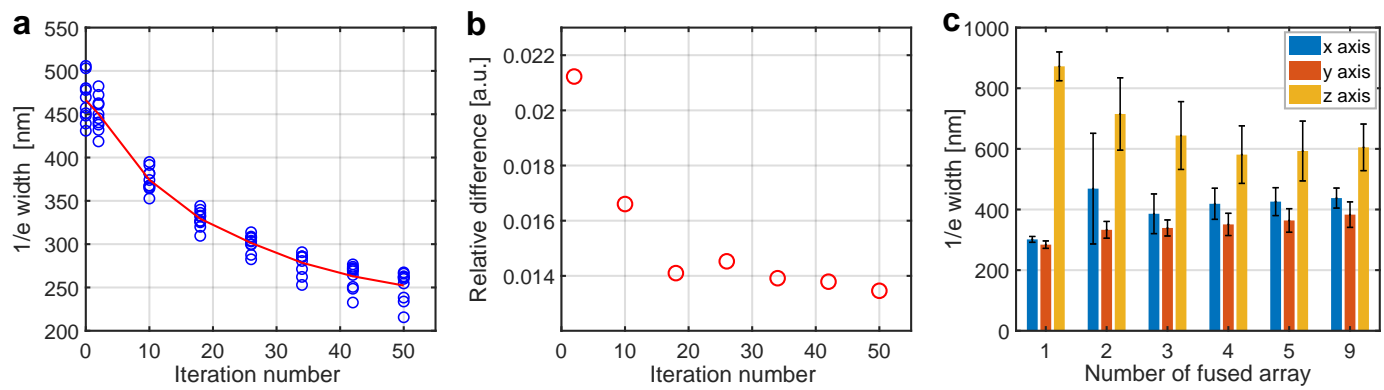

3.17. ábra. A dekonvolúció iterációs lépésszámának, valamint az összeillesztett képsorozatok számának vizsgálata. a) 8 darab mikrogolyó képeinek Gauss illesztéssel kapott laterális 1/e szélességei, és átlaguk (piros vonal) az iterációs szám függvényében. b) A mikrogolyók képsorozatának relatív változása az iterációs lépesek között. c) 6 darab kiválasztott mikrogolyóból számolt átlagos méretek függése három irányban a különböző nézőpontú képsorozatok számától, a Fourier alapú fuziót alkalmazva.

Az eredmények alapján a 26 iterációs lépést találtam optimálisnak. Ekkora a mikrogolyók dekonvolvált képeire laterálisan illesztett Gauss függvények átlagos 1/e széles- 
sége eléri a képalkotó rendszer felbontását $(0.61 \lambda / \mathrm{NA}=310 \mathrm{~nm}$, ahol $\lambda=610 \mathrm{~nm}$ és $\mathrm{NA}=1.2)$, valamint a dekonvolúciós lépések közötti relatív változás is beáll egy szintre. A 3.18.a és b ábrán látható a mikrogolyók három-dimenziós eredeti és a 26 iterációval dekonvolvált képsorozatának oldalirányú nézete. Látható, hogy a dekonvolúció eltávolítja az egyes mikrogolyókból származó fókuszon kívüli intenzitásokat, de megtartja azoknak a fókuszba esô, legintenzívebb, elnyúlt alakú képét.
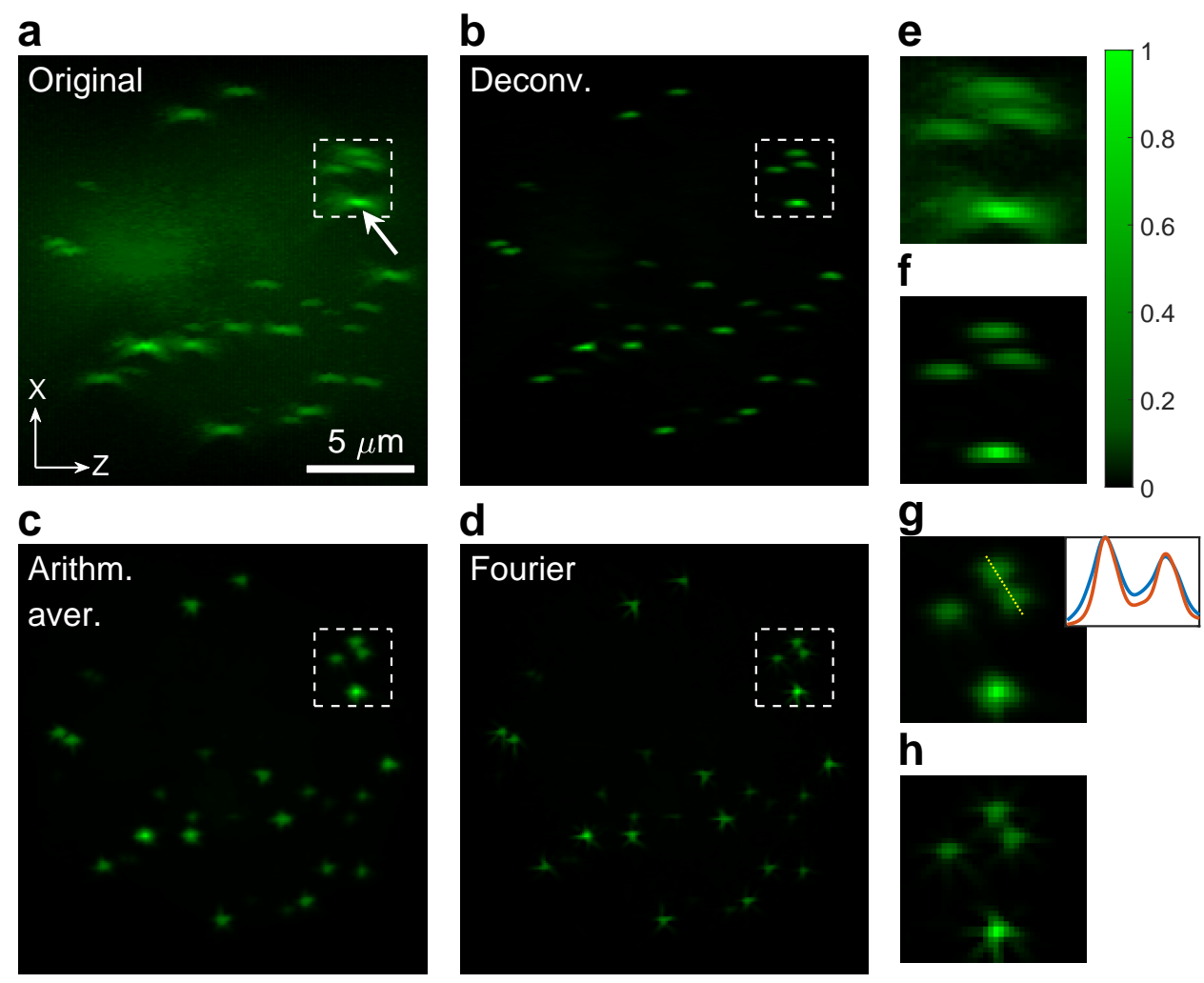

3.18. ábra. A mikrogolyókról felvett fluoreszcens képsorozat XZ nézetú maximum intenzitás projekciói. a) A feldolgozatlan, eredeti felvétel. b) a 26 iterációval elvégzett dekonvolúció eredménye ( $0^{\circ}$ orientáció). c) és d) a 4 különbözó irányú $\left(0^{\circ}, 45^{\circ}, 90^{\circ}, 135^{\circ}\right)$ felvételekból átlagolással, illetve a Fourier-módszerrel fuzionált eredmények. e-h) 4 darab mikrogolyó csoportjának kinagyított képei az a)-d) panelekrôl. A g) panel melletti beszúrt képen látható görbék a g) panelen bejelölt vonal menti intenzitás profilt mutatják az átlagolással (kék) és a Fourier-módszerrel (piros) kapott fuzionált képekre.

A dekonvolúció után a képsorozatokat térben egymáshoz regisztráltam, ami elófeltétel a sikeres fúziójukhoz. Mivel a különböző nézetú képsorozatok fúziójának nincs egy standard elmélete, a multiview mikroszkópiában számos algoritmust alkalmaznak rá. Ennek fényében én kettô algoritmust próbáltam ki, az egyik legegyszerúbb, képtérbeli átlagolást, valamint egy gyakran alkalmazott másik módszert ami a képsorozatokat a térbeli frekvenciatérben kombinálja (Fourier-módszer) [114,115] (lásd módszerek). A különböző nézôpontok optimális számának meghatározására megvizsgáltam a mikrogolyók háromirányú kiterjedéseit a Fourier-módszerrel fuzionált képsorozatokon (3.17.c ábra). Látható, hogy 
mikrogolyók axiális (z-irányú) mérete 4 irány fúziója esetén lesz a legkisebb, körülbelül $580 \mathrm{~nm}$. Ez sajnos nem éri el a golyók laterális irányú kiterjedését, még úgy sem, hogy az kis mértékben megnô a fuzionált képsorozaton. Ez a mikrogolyók képeinek nem tökéletes átfedésével magyarázható, a térbeli regisztrációs lépés után azok átlagos távolságát körülbelül 150 nm-nek mértem. Ennek okának a sejtfelszínhez tapasztott mikrogolyók nem merev kapcsolódása valószínúsíthető, ami miatt a képalkotás során azok kismértékben fluktuálhattak, esetleg el is mozdulhattak az egyes képsorozatok felvétele között.

A legjobb felbontást adó, 4 különböző orientációjú $\left(0^{\circ}, 45^{\circ}, 90^{\circ}, 135^{\circ}\right)$ mikrogolyó képsorozatokból képzett fuziók eredményei a 3.18.c-d ábrákon figyelhetőek meg. Az eredeti, a dekonvolvált és a fuzionált felvételekról kivágott 4 darab mikrogolyóból álló csoport képei a 3.18.e-h paneleken összehasonlíthatóak. Látható, hogy a multiview fuzionálás eredményeként a mikrogolyók képei jóval kerekebbek, az anizotrop felbontásból eredő megnyúltságuk megszűnik. A két különböző képsorozat fuziós módszer összehasonlítása végett megvizsgáltam két szomszédos mikrogolyó képének a 3.18.g panelen bejelölt vonalnak megfelelően vett intenzitás profilját, ami az inzert képen látható. Ez alapján megállapítható, hogy a Fourier-módszer (piros görbe) eredménye nagyobb kontrasztot eredményez az átlagoláshoz (kék görbe) képest.

\section{Mitokondrium festett sejt három-dimenziós struktúrája}
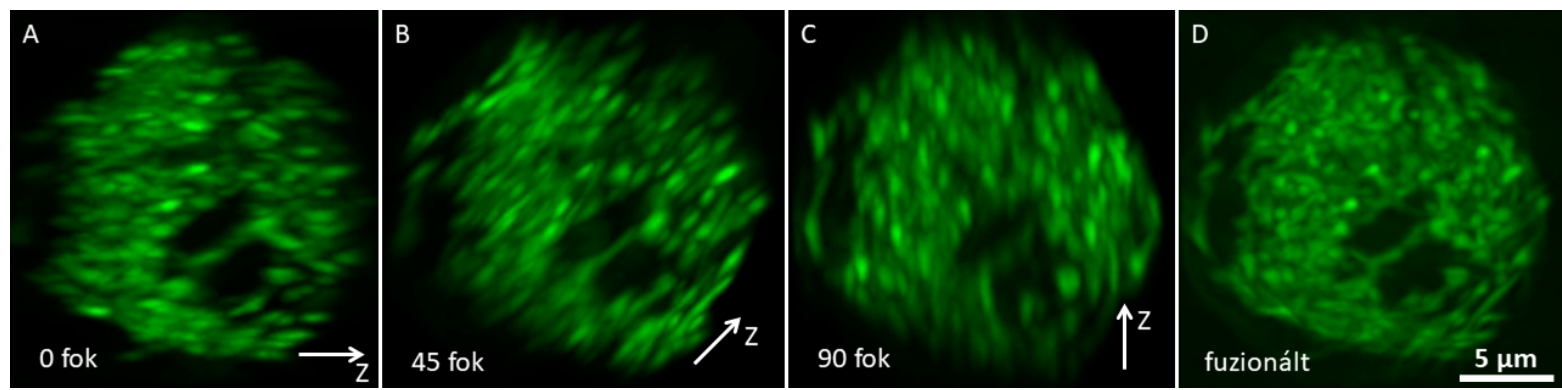

3.19. ábra. Egy mitokondrium festett sejt multiview mikroszkópiája. a-c) Dekonvolvált és térben egymáshoz regisztrált, különbözô irányú felvételek maximum intenzitás projekciói. Az egyes felvételekhez tartozó optikai tengelyeket nyilak jelölik. d) Az összesen rögzített, 4 különböző orientációjú $\left(0^{\circ}, 45^{\circ}, 90^{\circ}, 135^{\circ}\right)$ felvételek fúziójának eredménye.

A mitokondrium festett sejtekról 4 különböző orientációjú $\left(0^{\circ}, 45^{\circ}, 90^{\circ}, 135^{\circ}\right)$ képsorozatot vettem fel. Ezen felvételek dekonvolúciója során 60 iterációt alkalmaztam, amit az alapján határoztam meg, hogy a dekonvolvált felvételek térbeli frekvencia tartalma (spatial frequency power spectrum) ekkorra közelíti meg az optikai leképezô rendszer modulációs átviteli függvényének szélességét (3.20.c ábra). Egy sejtről készült különbözô irányú felvételeket, valamint a fúziójuk eredményét a 3.19 ábra mutatja be, illetve megtekinthető videó formájában is a következő hivatkozást követve: [117]. Megfigyelhetô, hogy a K562 sejtek esetén tipikusan $0.5 \mu \mathrm{m}$ méretú mitokondriumok az egynézetú felvételeken elnyúlt 
alakú foltokként jelennek meg, axiális irányban gyakran egymással összeolvadva. Ezzel szemben a multiview képalkotás eredményeként a mitokondriumok képeinek megnyúltsága megszúnik, az egymással egybe olvadt részletek felhasadnak, összességében jóval több részlet figyelhető meg. Ez szintén megfigyelhető a 3.20.a ábrán, ahol a nyers, dekonvolvált, illetve fuzionált képsorozatok egy-egy reprezentatív szelete látható, a [ZX, ZY, XY] tengelyekkel párhuzamos síkokból. Az axiális feloldás javulása egyértelmúen látható a 3.20.b ábrán bemutatott intenzitás görbéken felhasadó csúcsokon. Amíg a mikrogolyókról készült felvételeken direkt módon mérhetô volt a háromirányú felbontás, a mitokondrium felvételek esetén ez nem lehetséges. Ezért ezen felvételek felbontásának kiértékelésére megvizsgáltam azok Fourier-transzformációval számolható térbeli frekvencia tartalmát, aminek eredménye a 3.20.c ábrán látható. Egy egynézetú képsorozat frekvencia tartalma (középsố panel) tipikusan aszimmetrikus, a $k_{z}$ irányban keskenyebb, hasonlóan az képalkotó rendszer modulációs átviteli függvényéhez (felsố panel). A fuzionált képsorozat térbeli frekvencia tartalma a $k_{z}$ irányban jelentősen szélesebb (alsó panel), összességében jóval körszimmetrikusabb, közel izotrop felbontást jelezve.
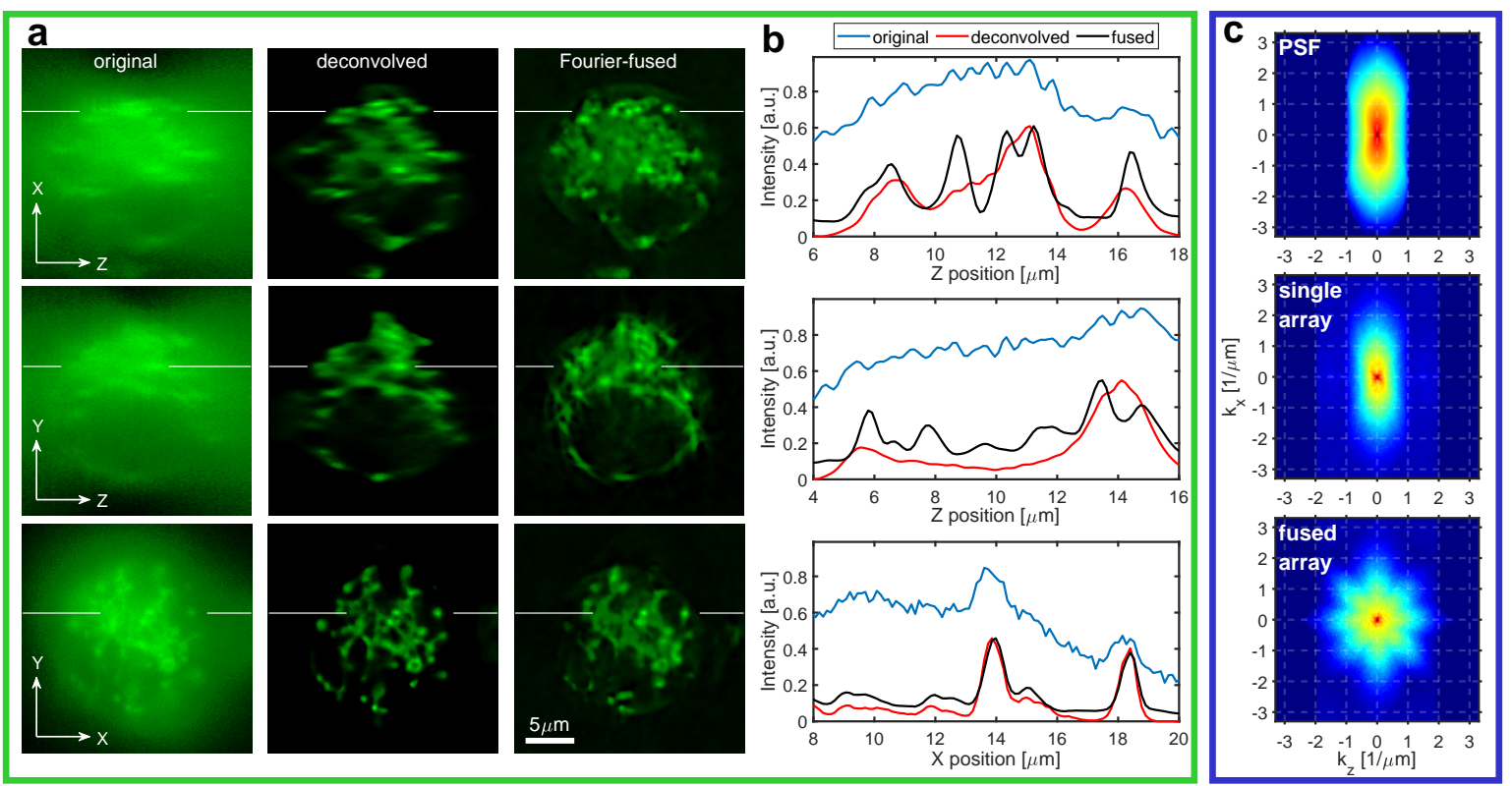

3.20. ábra. Felbontás javulás egy mitokondrium festett sejt esetén. a) A $0^{\circ}$ orientációjú eredeti és dekonvolvált, valamint a Fourier-módszerrel fuzionált képsorozatokból vett reprezentatív szeletek, három különböző nézetből (ZX, ZY, XY). b) Az a-panelen fehérrel jelölt vonalak közötti intenzitás profilok görbéi. c) Fentrôl lefelé: az optikai rendszer PSF-jéból Fourier-transzformációval számolt modulációs átviteli függvény $(\mathrm{MTF})$; a 60 iterációval dekonvolvált $0^{\circ}$ orientációjú képsorozat térbeli frekvencia tartalma (power spectrum); a 4 különböző nézetú képsorozat fúziójának térbeli frekvencia tartalma. Mindhárom ábrázolás $(\mathrm{KZ}, \mathrm{KX})$ nézetú a frekvencia térben. 


\subsubsection{Konklúzió}

Bemutattam, hogy a két-fotonos polimerizáció módszerével készített, holografikus optikai csipesszel csapdázható mikrostruktúrák kiválóan alkalmazhatóak egyedüli sejtek indirekt módon történô optikai manipulációjára. A kifejlesztett mikromanipulátor struktúra optimális alakja révén más optikai módszerekkel korábban nem lehetséges precizitással és stabilitással teszi lehetôvé sejtek 6 szabadsági fokú térbeli manipulációját. Ez az új, mikrostruktúra alapú indirekt optikai sejt manipulációs módszer inherensen alkalmazható az úgynevezett multiview mikroszkópia elvégzésére is. Ennek megvalósításához megépítettem egy fluoreszcens mikroszkóppal kombinált holografikus lézercsipesz rendszert, valamint elkészítettem egy olyan vezérlő szoftvert ami a holografikus lézercsipesz irányításán keresztül lehetôvé teszi fluoreszcens képsorozatok felvételét a manipulált sejtrôl. A multiview képalkotás felbontását, és a különbözô nézôpontok optimális számát sejtfelszínhez tapasztott mikrogolyókról készült felvételek alapján jellemeztem. Teljesen izotrop felbontást nem sikerült elérni, aminek valószínúsíthetô oka a mikrogolyók nem teljesen merev kapcsolódása volt. A módszert sikeresen alkalmaztam egy három-dimenziós biológiai struktúra, egy mitokondrium festett sejt közel izotrop felbontású rekonstrukciójára. 


\section{Köszönetnyilvánítás}

Ezúton köszönöm témavezetômnek, Dr. Kelemen Lórándnak és Prof. Dr. Ormos Pálnak a szakmai tanácsaikat és, hogy kutatásaimhoz szükséges erőforrásokat, eszközöket rendelkezésemre bocsátották. Továbbá köszönetemet szeretném kifejezni, hogy lehetôvé tették a szakmai fejlődésemet elősegítô, és perspektívámat szélesítő nemzetközi konferenciákon való részvételeket. Köszönöm a Magyar Tudományos Akadémia Szegedi Biológiai Kutatóközpontjának és annak Biofizikai Intézetének a kutatásaimhoz szükséges erőforrások megteremtését.

Hálás vagyok az NVIDIA Corporation-nek, hogy GPU GRANT programjuk keretében rendelkezésünkre bocsátottak egy TITAN Xp típusú grafikus kártyát.

Doktori munkámat a GINOP-2.3.2-15-2016-00001 és a GINOP-2.3.3-15-2016-00040 pályázati források támogatták. 


\section{Összefoglalás}

Doktori dolgozatomban bemutattam, hogy a két-fotonos polimerizáció technikája, valamint a holografikus optikai csipesz alkalmazása kölcsönösen kiterjeszthető: i) a két-fotonos polimerizációban kiválóan alkalmazható a holografikus optikai csipesz alapját adó, holografikus lézernyaláb formázás; ii) a holografikus optikai csipesz alkalmazása sejtek térbeli manipulációjára jelentôsen továbbfejleszthetô két-fotonos polimerizációval készült mikrostruktúrák felhasználásával.

[T1]: Megvalósítottam a két-fotonos polimerizáció egy olyan új módját, amely lehetôvé teszi egyes mikrostruktúrák párhuzamosan több fókuszpont általi polimerizációját, felgyorsítva a gyártási folyamatot. Ehhez a holografikus lézernyaláb formázás technikáját alkalmaztam: egy térbeli fázismodulátorral a TPP rendszer lézernyalábját több holografikus nyalábra osztottam, amelyeket különálló fókuszokba képez le a rendszer fókuszáló objektíve. Az így létrehozott többszörös fókuszok koordinált mozgatására egy vezérlő szoftver írtam, amely a rendszerbe épített SLM saját frissítésével szinkronban változtatja a nyalábosztó hologramot. A hologramok számolására egy optimalizált algoritmust alkalmaztam, amellyel közel egyforma intenzitású holografikus fókuszok állíthatóak elő precíz három-dimenziós koordinátákban. A módszert olyan mikrostruktúrák gyártásával teszteltem, amelyeket párhuzamosan 5 holografikus fókusz exponált. A legyártott mikrostruktúrákon végzett mérések eredményei alapján kijelenthető, hogy a holografikusan létrehozott és mozgatott fókuszok kiválóan alkalmazhatóak a két-fotonos polimerizációban. A módszerrel $9 \mu \mathrm{m} / \mathrm{s}$ pásztázási sebességet értem el, de egy nagyobb frissítési frekvenciájú SLM-mel ez akár egy nagyságrenddel is nagyobb lehet.

[T2]: Kifejlesztettem egy olyan, két-fotonos polimerizációval készülő mikrostruktúrát, amely alkalmazásával a biológiai sejtek optikai manipulációjának módszere jelentôsen feljavítható. A holografikus optikai csipesszel megfogható, biokémiailag funkcionalizált mikromanipulátor struktúrához könnyedén hozzátapasztható egy kiválasztott sejt. A mikromanipulátor, optimális alakjának és törésmutatójának köszönhetôen, lehetôvé teszi a megfogott sejt nagy stabilitású, 6 szabadsági fokú térbeli manipulációját, miközben elkerüli a sejt érintkezését a holografikus optikai csipesz nagy intenzitású lézernyalábjaival. A csapdázott sejt laterális térbeli fluktuációja (x: $90 \mathrm{~nm}, \mathrm{y}: 150 \mathrm{~nm}$ ) megfelelően alacsony ahhoz, hogy elmosódás mentesen lehessen akár hosszú expozíciós idejú felvételeket is készíteni a sejtrôl. Mindez együttesen jelentôs eloorelépés a sejtek optikai manipulációjának 
korábbi módjaihoz képest.

[T3]: Sikeresen alkalmaztam a mikromanipulátor struktúrát sejtek multiview mikroszkópiájának kivitelezésére. Ehhez megépítettem egy fluoreszcens mikroszkóppal kombinált holografikus optikai csipesz rendszert. A holografikus optikai manipuláció és a multiview képalkotás irányítására egy saját szoftvert írtam. A multiview képalkotás jellemzése után demonstráltam, hogy a módszerrel közel izotrop felbontással rekonstruálható egy sejt három-dimenziós szerkezete. 


\section{Summary}

In my doctoral thesis i have shown, that the technique of two-photon polymerization, and the application of holografic optical tweezers can be mutually extended: i) the method of holographic beam shaping, used in holographic optical tweezers, can be very well applied in two-photon polymerization; ii) the application of holographic optical tweezers can be extended by the usage of two-photon polymerized microstructures.

[T1]: I have implemented a novel mode of two-photon polymerization that enables the fabrication of singe microstructures with multiple foci, thereby speeding up the fabrication process. For this i have applied the method of holographic beam shaping: using a spatial light modulator i split the laser beam of the TPP system into multiple holographic beams, each of which is projected into a distinct focus by the focusing objective of the system. For the coordinated movement of the holographic foci i have written a control software that updates the beam splitting hologram on the SLM in synchrony with its internal refresh rate. For the calculation of the holograms i have applied an optimized algorithm that can create multiple foci with highly uniform intensities on precise threedimensional coordinates. I have tested the holographic TPP method by fabricating test microstructures that were exposed by 5 holographic foci. From the evaluation of the fabricated microstructures i conclude that holographically created and translated foci can be very well used in two-photon polymerization. The achieved scanning speed of $9 \mu \mathrm{m} / \mathrm{s}$ can be easily increased with the application of a higher refresh rate SLM.

[T2]: I have developed a microstructure, produced by two-photon polymerization that can greatly enhance the method of optical trapping of biological cells. This micromanipulator structure can be trapped with holographic optical tweezers, and its biochemical surface functionalization enables it to be easily attached to a targeted cell. Through its optimal shape and refractive index, the micromanipulator enables the high precision, 6 degrees of freedom spatial manipulation of the trapped cell, while avoiding the cell's exposure to the high intensity beams of the holographic optical traps. The trapped cell's lateral spatial fluctuation is low enough (x: $90 \mathrm{~nm}, \mathrm{y}: 150 \mathrm{~nm})$ to allow the unblurred imaging of the trapped cell, even with long exposure times. Overall, this is a great improvement over the previous modes of optical manipulation of biological cells.

[T3]: I have successfully applied the micromanipulator based cell manipulation to perform multiview imaging. For this i have built a holographic optical tweezers system 
combined with a fluorescent microscope. I have written a dedicated software for the control of the holographic optical manipulation and the multiview imaging. I have characterized the multiview imaging, and shown that it is capable of isotropic resolution reconstruction of the three-dimensional structure of a biological cell. 


\section{Publikációs lista}

https://scholar google.hu/citations?user=hcgq8uwAAAAJ

1. Lóránd Kelemen, Pál Ormos, and Gaszton Vizsnyiczai. Two-photon polymerization with optimized spatial light modulator. Journal of the European Optical SocietyRapid publications, 6, 2011.

2. R Di Leonardo, András Búzás, Lóránd Kelemen, Gaszton Vizsnyiczai, László Oroszi, and Pál Ormos. Hydrodynamic synchronization of light driven microrotors. Physical Review Letters, 109(3):034104, 2012.

3. Darwin Palima, Andrew Rafael Bañas, Gaszton Vizsnyiczai, Lóránd Kelemen, Pál Ormos, and Jesper Glückstad. Wave-guided optical waveguides. Optics Express, 20(3):2004-2014, 2012.

4. Anrdás Búzás, Lóránd Kelemen, Anna Mathesz, László Oroszi, Gaszton Vizsnyiczai, Tamás Vicsek, and Pál Ormos. Light sailboats: Laser driven autonomous microrobots. Applied Physics Letters, 101(4):041111, 2012.

5. Darwin Palima, Andrew Rafael Bañas, Gaszton Vizsnyiczai, Lóránd Kelemen, Thomas Aabo, Pál Ormos, and Jesper Glückstad. Optical forces through guided light deflections. Optics Express, 21(1):581-593, 2013.

6. T1. Gaszton Vizsnyiczai, Lóránd Kelemen, and Pál Ormos. Holographic multi-focus 3D two-photon polymerization with real-time calculated holograms. Optics Express, 22(20):24217-24223, 2014.

7. Gaszton Vizsnyiczai, Tamás Lestyán, Jaroslava Joniova, Badri L. Aekbote, Alena Strejčková, Pál Ormos, Pavol Miskovsky, Lóránd Kelemen, and Gregor Bánó. Optically trapped surface-enhanced raman probes prepared by silver photoreduction to 3D microstructures. Langmuir, 31(36):10087-10093, 2015.

8. László Oroszi, András Búzás, Péter Galajda, Lóránd Kelemen, Anna Mathesz, Tamás Vicsek, Gaszton Vizsnyiczai, and Pál Ormos. Dimensionality constraints of light-induced rotation. Applied Physics Letters, 107(20):204106, 2015. 
9. Badri L Aekbote, Tamás Fekete, Jaroslaw Jacak, Gaszton Vizsnyiczai, Pál Ormos, and Lóránd Kelemen. Surface-modified complex su-8 microstructures for indirect optical manipulation of single cells. Biomedical Optics Express, 7(1):45-56, 2016.

10. Silvio Bianchi, Riccardo Pruner, Gaszton Vizsnyiczai, Claudio Maggi, and Roberto Di Leonardo. Active dynamics of colloidal particles in time-varying laser speckle patterns. Scientific Reports, $6: 27681,2016$.

11. T2. Gaszton Vizsnyiczai, Badri L Aekbote, András Buzás, István Grexa, Pál Ormos, and Lóránd Kelemen. High accuracy indirect optical manipulation of live cells with functionalized microtools. In Optical Trapping and Optical Micromanipulation XIII, volume 9922, page 992216. International Society for Optics and Photonics, 2016.

12. Gaszton Vizsnyiczai, Giacomo Frangipane, Claudio Maggi, Filippo Saglimbeni, Silvio Bianchi, and Roberto Di Leonardo. Light controlled 3d micromotors powered by bacteria. Nature Communications, 8:15974, 2017.

13. Giacomo Frangipane, Dario Dell'Arciprete, Serena Petracchini, Claudio Maggi, Filippo Saglimbeni, Silvio Bianchi, Gaszton Vizsnyiczai, Maria Lina Bernardini, and Roberto Di Leonardo. Dynamic density shaping of photokinetic E. coli. Elife, $7: \mathrm{e} 36608,2018$.

14. Silvio Bianchi, Gaszton Vizsnyiczai, Stefano Ferretti, Claudio Maggi, and Roberto Di Leonardo. An optical reaction micro-turbine. Nature Communications, 9(1):4476, 2018.

15. Giacomo Frangipane, Gaszton Vizsnyiczai, Claudio Maggi, Romolo Savo, Alfredo Sciortino, Sylvain Gigan, and Roberto Di Leonardo. Invariance properties of bacterial random walks in complex structures. Nature Communications, 10(1):2442, 2019 .

16. T3. Gaszton Vizsnyiczai, András Buzás, Badri L Aekbote, Tamás Fekete, István Grexa, Pál Ormos, and Lóránd Kelemen. Multiview microscopy of single cells through microstructure-based indirect optical manipulation. Elérhetô az arXiv preprint szerveren (arxiv.org). 


\section{IRODALOMJEGYZÉK}

[1] Shoji Maruo, Osamu Nakamura, and Satoshi Kawata. Three-dimensional microfabrication with two-photon-absorbed photopolymerization. Opt. Lett., 22(2):132134, Jan 1997.

[2] Péter Galajda and Pál Ormos. Complex micromachines produced and driven by light. Applied Physics Letters, 78(2):249-251, 2001.

[3] Satoshi Kawata, Hong-Bo Sun, Tomokazu Tanaka, and Kenji Takada. Finer features for functional microdevices. Nature, 412(6848):697-698, August 2001.

[4] Karel Svoboda, Christoph F. Schmidt, Bruce J. Schnapp, and Steven M. Block. Direct observation of kinesin stepping by optical trapping interferometry. Nature, 365:721-, October 1993.

[5] J. E. Molloy, J. E. Burns, J. Kendrick-Jones, R. T. Tregear, and D. C. S. White. Movement and force produced by a single myosin head. Nature, $378: 209-$, November 1995.

[6] Steven B. Smith, Yujia Cui, and Carlos Bustamante. Overstretching b-dna: The elastic response of individual double-stranded and single-stranded dna molecules. Science, 271(5250):795-799, 1996.

[7] M. Reicherter, T. Haist, E. U. Wagemann, and H. J. Tiziani. Optical particle trapping with computer-generated holograms written on a liquid-crystal display. Opt. Lett., 24(9):608-610, May 1999.

[8] Jennifer E. Curtis, Brian A. Koss, and David G. Grier. Dynamic holographic optical tweezers. Optics Communications, 207(1):169 - 175, 2002.

[9] G M Akselrod, W Timp, U Mirsaidov, Q Zhao, C Li, R Timp, K Timp, P Matsudaira, and G Timp. Laser-guided assembly of heterotypic three-dimensional living cell microarrays. Biophysical journal, 91(9):3465-3473, November 2006.

[10] Lóránd Kelemen, Huba Kirei, Sándor Valkai, and Pál Ormos. Optically driven micromachines for biotechnological applications, 2005. 
[11] Lóránd Kelemen, Sándor Valkai, and Pál Ormos. Integrated optical motor. Appl. Opt., 45(12):2777-2780, Apr 2006.

[12] Peter John Rodrigo, Lóránd Kelemen, Carlo Amadeo Alonzo, Ivan R. Perch-Nielsen, Jeppe Seidelin Dam, Pál Ormos, and Jesper Glückstad. 2d optical manipulation and assembly of shape-complementary planar microstructures. Opt. Express, 15(14):9009-9014, Jul 2007.

[13] Peter John Rodrigo, Lóránd Kelemen, Darwin Palima, Carlo Amadeo Alonzo, Pál Ormos, and Jesper Glückstad. Optical microassembly platform for constructing reconfigurable microenvironments for biomedical studies. Opt. Express, 17(8):65786583, Apr 2009.

[14] L. Kelemen, P. Ormos, and G. Vizsnyiczai. Two-photon polymerization with optimized spatial light modulator. Journal of the European Optical Society - Rapid publications, 6(0):-, 2011.

[15] R. Di Leonardo, A. Búzás, L. Kelemen, G. Vizsnyiczai, L. Oroszi, and P. Ormos. Hydrodynamic synchronization of light driven microrotors. Phys. Rev. Lett., 109:034104, Jul 2012.

[16] D. Palima, A. R. Bañas, G. Vizsnyiczai, L. Kelemen, P. Ormos, and J. Glückstad. Wave-guided optical waveguides. Opt. Express, 20(3):2004-2014, Jan 2012.

[17] Darwin Palima, Andrew Rafael Bañas, Gaszton Vizsnyiczai, Lóránd Kelemen, Thomas Aabo, Pál Ormos, and Jesper Glückstad. Optical forces through guided light deflections. Opt. Express, 21(1):581-593, Jan 2013.

[18] Gaszton Vizsnyiczai, Tamás Lestyán, Jaroslava Joniova, Badri L. Aekbote, Alena Strejčková, Pál Ormos, Pavol Miskovsky, Lóránd Kelemen, and Gregor Bánó. Optically trapped surface-enhanced raman probes prepared by silver photoreduction to 3D microstructures. Langmuir, 31(36):10087-10093, 2015. PMID: 26292094.

[19] Gaszton Vizsnyiczai, Lóránd Kelemen, and Pál Ormos. Holographic multi-focus 3D two-photon polymerization with real-time calculated holograms. Opt. Express, 22(20) :24217-24223, Oct 2014.

[20] Badri L. Aekbote, Tamás Fekete, Jaroslaw Jacak, Gaszton Vizsnyiczai, Pál Ormos, and Lóránd Kelemen. Surface-modified complex SU-8 microstructures for indirect optical manipulation of single cells. Biomed. Opt. Express, 7(1):45-56, Jan 2016.

[21] Gaszton Vizsnyiczai, Badri L Aekbote, András Buzás, István Grexa, Pál Ormos, and Lóránd Kelemen. High accuracy indirect optical manipulation of live cells with 
functionalized microtools. In Optical Trapping and Optical Micromanipulation XIII, volume 9922, page 992216. International Society for Optics and Photonics, 2016.

[22] W Denk, JH Strickler, and WW Webb. Two-photon laser scanning fluorescence microscopy. Science, 248(4951):73-76, 1990.

[23] En-Shinn Wu, James H. Strickler, W. R. Harrell, and Watt W. Webb. Two-photon lithography for microelectronic application, 1992.

[24] Michael Thiel, Michael S Rill, Georg von Freymann, and Martin Wegener. Threedimensional bi-chiral photonic crystals. Advanced Materials, 21(46):4680-4682, 2009.

[25] Sima Rekstyte, Justinas Maciulaitis, Romaldas Maciulaitis, and Mangirdas Malinauskas. Fabrication of 3d micro-structured scaffolds by direct laser writing in pre-polymers for in vitro and in vivo studies, 2017.

[26] Yong-Lai Zhang, Qi-Dai Chen, Hong Xia, and Hong-Bo Sun. Designable 3d nanofabrication by femtosecond laser direct writing. Nano Today, 5(5):435 - 448, 2010.

[27] Martin Straub and Min Gu. Near-infrared photonic crystals with higher-order bandgaps generated by two-photon photopolymerization. Opt. Lett., 27(20):18241826, Oct 2002 .

[28] M. Deubel, M. Wegener, S. Linden, G. von Freymann, and S. John. 3d-2d-3d photonic crystal heterostructures fabricated by direct laser writing. Opt. Lett., 31(6) :805-807, Mar 2006.

[29] Yihong Liu, David D. Nolte, and Laura J. Pyrak-Nolte. Large-format fabrication by two-photon polymerization in su-8. Applied Physics A, 100(1):181-191, Jul 2010.

[30] Shoji Maruo and Hiroyuki Inoue. Optically driven micropump produced by threedimensional two-photon microfabrication. Applied Physics Letters, 89(14):144101, 2006.

[31] Rex Nielson, Bryan Kaehr, and Jason B. Shear. Microreplication and design of biological architectures using dynamic-mask multiphoton lithography. Small, 5(1):120$125,2009$.

[32] Jan Torgersen, Xiao-Hua Qin, Zhiquan Li, Aleksandr Ovsianikov, Robert Liska, and Jürgen Stampfl. Hydrogels for two-photon polymerization: A toolbox for mimicking the extracellular matrix. Advanced Functional Materials, 23(36) :4542-4554, 2013. 
[33] Kwang-Sup Lee, Ran Hee Kim, Dong-Yol Yang, and Sang Hu Park. Advances in 3d nano/microfabrication using two-photon initiated polymerization. Progress in Polymer Science, 33(6):631 - 681, 2008.

[34] Katherine J Schafer, Joel M Hales, Mihaela Balu, Kevin D Belfield, Eric W Van Stryland, and David J Hagan. Two-photon absorption cross-sections of common photoinitiators. Journal of Photochemistry and Photobiology A: Chemistry, 162(2):497 - 502, 2004.

[35] Michael Thiel and Martin Hermatschweiler. Three-dimensional laser lithography. Optik \& Photonik, 6(4):36-39, 2011.

[36] László Oroszi, András Búzás, Péter Galajda, Lóránd Kelemen, Anna Mathesz, Tamás Vicsek, Gaszton Vizsnyiczai, and Pál Ormos. Dimensionality constraints of light-induced rotation. Applied Physics Letters, 107(20):204106, 2015.

[37] Hong-Bo Sun, Kenji Takada, Moon-Soo Kim, Kwang-Sup Lee, and Satoshi Kawata. Scaling laws of voxels in two-photon photopolymerization nanofabrication. Applied Physics Letters, 83(6):1104-1106, 2003.

[38] Akihiko Kono, Yu Arai, Takeshi Maruoka, Masashi Yamamoto, Yousuke Goto, Seiji Takahashi, Takashi Nishiyama, and Hideo Horibe. High removal rate of cross-linked su- 8 resist using hydrogen radicals generated by tungsten hot-wire catalyzer. Thin Solid Films, 562:632 - 637, 2014.

[39] Peter Lebedew. Untersuchungen über die druckkräfte des lichtes. Annalen der Physik, 311(11):433-458, 1901.

[40] E. F. Nichols and G. F. Hull. A preliminary communication on the pressure of heat and light radiation. Phys. Rev. (Series I), 13:307-320, Nov 1901.

[41] A. Ashkin. Acceleration and trapping of particles by radiation pressure. Phys. Rev. Lett., 24:156-159, Jan 1970.

[42] Arthur Ashkin. Atomic-beam deflection by resonance-radiation pressure. Physical Review Letters, 25(19):1321, 1970.

[43] R Schieder, H Walther, and L Wöste. Atomic beam deflection by the light of a tunable dye laser. Optics Communications, 5(5):337-340, 1972.

[44] Anthony F. Bernhardt. Isotope separation by laser deflection of an atomic beam. Applied physics, 9(1):19-34, Jan 1976.

[45] T.W. Hänsch and A.L. Schawlow. Cooling of gases by laser radiation. Optics Communications, 13(1):68 - 69, 1975. 
[46] A. Ashkin. Trapping of atoms by resonance radiation pressure. Phys. Rev. Lett., 40:729-732, Mar 1978.

[47] M. H. Anderson, J. R. Ensher, M. R. Matthews, C. E. Wieman, and E. A. Cornell. Observation of bose-einstein condensation in a dilute atomic vapor. Science, 269(5221):198-201, 1995.

[48] A. Ashkin, J. M. Dziedzic, J. E. Bjorkholm, and Steven Chu. Observation of a singlebeam gradient force optical trap for dielectric particles. Opt. Lett., 11(5):288-290, May 1986.

[49] A ray optics interactive simulation of trapping force in optical tweezers. http: //www.roma1.infn.it/ dileorob/content/apps/trapforces.php.

[50] Timo A. Nieminen, Gregor Knöner, Norman R. Heckenberg, and Halina Rubinsztein-Dunlop. Physics of optical tweezers. In Laser Manipulation of Cells and Tissues, volume 82 of Methods in Cell Biology, pages 207 - 236. Academic Press, 2007.

[51] T.A. Nieminen, H. Rubinsztein-Dunlop, N.R. Heckenberg, and A.I. Bishop. Numerical modelling of optical trapping. Computer Physics Communications, 142(1):468 - 471, 2001. Conference on Computational Physics 2000 :.

[52] Timo A Nieminen, Vincent L Y Loke, Alexander B Stilgoe, Gregor Knöner, Agata M Brańczyk, Norman R Heckenberg, and Halina Rubinsztein-Dunlop. Optical tweezers computational toolbox. Journal of Optics A: Pure and Applied Optics, 9(8) :S196-S203, jul 2007.

[53] K. Sasaki, M. Koshioka, H. Misawa, N. Kitamura, and H. Masuhara. Pattern formation and flow control of fine particles by laser-scanning micromanipulation. Optics letters, 16:1463-5, Oct 1991.

[54] Karen C Vermeulen, Joost van Mameren, Ger JM Stienen, Erwin JG Peterman, Gijs JL Wuite, and Christoph F Schmidt. Calibrating bead displacements in optical tweezers using acousto-optic deflectors. Review of Scientific Instruments, $77(1): 013704,2006$.

[55] Emma Eriksson, David Engström, Jan Scrimgeour, and Mattias Goksör. Automated focusing of nuclei for time lapse experiments on single cells using holographic optical tweezers. Opt. Express, 17(7):5585-5594, Mar 2009.

[56] J Arlt, V Garces-Chavez, W Sibbett, and K Dholakia. Optical micromanipulation using a bessel light beam. Optics Communications, 197(4):239 - 245, 2001. 
[57] S. H. Tao, W. M. Lee, and X.-C. Yuan. Dynamic optical manipulation with a higher-order fractional bessel beam generated from a spatial light modulator. Opt. Lett., 28(20):1867-1869, Oct 2003.

[58] David G. Grier. A revolution in optical manipulation. Nature, 424(6950):810-816, August 2003.

[59] Richard W Bowman, Amanda J Wright, and Miles J Padgett. An SLM-based shack-hartmann wavefront sensor for aberration correction in optical tweezers. Journal of Optics, 12(12):124004, nov 2010.

[60] Tomáš Čižmár, Michael Mazilu, and Kishan Dholakia. In situ wavefront correction and its application to micromanipulation. Nature Photonics, 4:388-, May 2010.

[61] Larry J. Hornbeck. Deformable-mirror spatial light modulators, 1990.

[62] M. Hacker, G. Stobrawa, R. Sauerbrey, T. Buckup, M. Motzkus, M. Wildenhain, and A. Gehner. Micromirror slm for femtosecond pulse shaping in the ultraviolet. Applied Physics B, 76(6):711-714, Jun 2003.

[63] Zichen Zhang, Zheng You, and Daping Chu. Fundamentals of phase-only liquid crystal on silicon (lcos) devices. Light: Science \&f Applications, 3:e213-, October 2014.

[64] Bahaa E. A. Saleh and Malvin Carl Teich. Polarization and Crystal Optics, pages 193-237. John Wiley \& Sons, Inc., 2001.

[65] Holoeye Photonics AG. https://holoeye.com.

[66] Hamamatsu Photonics K.K. http://www.hamamatsu.com/us/en/index.html.

[67] Meadowlark Optics, Inc. https://www.meadowlark.com.

[68] Roberto Di Leonardo, Francesca Ianni, and Giancarlo Ruocco. Computer generation of optimal holograms for optical trap arrays. Opt. Express, 15(4):1913-1922, Feb 2007.

[69] S. Bianchi and R. Di Leonardo. Real-time optical micro-manipulation using optimized holograms generated on the GPU. Computer Physics Communications, 181(8):1444-1448, 2010.

[70] Alexander Jesacher and Martin J. Booth. Parallel direct laser writing in three dimensions with spatially dependent aberration correction. Opt. Express, 18(20):21090-21099, Sep 2010. 
[71] R. W. Gerchberg and W. Owen Saxton. A practical algorithm for the determination of the phase from image and diffraction plane pictures. Optik, 35:237-246, 1972.

[72] Lóránd Kelemen, Sándor Valkai, and Pál Ormos. Parallel photopolymerisation with complex light patterns generated by diffractive optical elements. Opt. Express, 15(22) :14488-14497, Oct 2007.

[73] Jun-ichi Kato, Nobuyuki Takeyasu, Yoshihiro Adachi, Hong-Bo Sun, and Satoshi Kawata. Multiple-spot parallel processing for laser micronanofabrication. Appl. Phys. Lett., 86(4):044102-, January 2005.

[74] Florian Formanek, Nobuyuki Takeyasu, Takuo Tanaka, Kenta Chiyoda, Atsushi Ishikawa, and Satoshi Kawata. Three-dimensional fabrication of metallic nanostructures over large areas by two-photon polymerization. Opt. Express, 14(2):800-809, Jan 2006.

[75] Shaun D Gittard, Alexander Nguyen, Kotaro Obata, Anastasia Koroleva, Roger J Narayan, and Boris N Chichkov. Fabrication of microscale medical devices by twophoton polymerization with multiple foci via a spatial light modulator. Biomedical optics express, 2(11):3167-3178, October 2011.

[76] Kotaro Obata, Jürgen Koch, Ulf Hinze, and Boris N. Chichkov. Multi-focus twophoton polymerization technique based on individually controlled phase modulation. Opt. Express, 18(16):17193-17200, Aug 2010.

[77] Eric T. Ritschdorff, Rex Nielson, and Jason B. Shear. Multi-focal multiphoton lithography. Lab Chip, 12:867-871, 2012.

[78] Nathan J. Jenness, Kurt D. Wulff, Matthew S. Johannes, Miles J. Padgett, Daniel G. Cole, and Robert L. Clark. Three-dimensional parallel holographic micropatterning using a spatial light modulator. Opt. Express, 16(20):15942-15948, Sep 2008.

[79] Freeglut library. http://freeglut.sourceforge.net.

[80] OpenGL vertical synchronization. https://www.khronos. org/opengl/wiki/Swap_Interval.

[81] Gaszton Vizsnyiczai, Lóránd Kelemen, and Pál Ormos. Media 1: Holographic multi-focus 3d two-photon polymerization with real-time calculated holograms. https://osapublishing.figshare.com/articles/Media_1_ Holographic_multi-focus_3D_two-photon_polymerization_with_real-time_calculated_holograms/4947368/1, Apr 2017. 
[82] Martin Persson, David Engström, Anders Frank, Jan Backsten, Jörgen Bengtsson, and Mattias Goksör. Minimizing intensity fluctuations in dynamic holographic optical tweezers by restricted phase change. Opt. Express, 18(11):11250-11263, May 2010.

[83] Gaszton Vizsnyiczai, Lóránd Kelemen, and Pál Ormos. Media 2: Holographic multi-focus 3d two-photon polymerization with real-time calculated holograms. https://osapublishing.figshare.com/articles/Media_2_ Holographic_multi-focus_3D_two-photon_polymerization_with_real-time_calculated_holograms/4947374/1, Apr 2017.

[84] Elio A. Abbondanzieri, William J. Greenleaf, Joshua W. Shaevitz, Robert Landick, and Steven M. Block. Direct observation of base-pair stepping by RNA polymerase. Nature, 438(7067) :460-465, 2005.

[85] Jens-Christian Meiners and Stephen R. Quake. Femtonewton force spectroscopy of single extended DNA molecules. Phys. Rev. Lett., 84:5014-5017, May 2000.

[86] Ineke Brouwer, Gerrit Sitters, Andrea Candelli, Stephanie J. Heerema, Iddo Heller, Abinadabe J. Melo de, Hongshan Zhang, Davide Normanno, Mauro Modesti, Erwin J. G. Peterman, and Gijs J. L. Wuite. Sliding sleeves of xrcc4-xlf bridge dna and connect fragments of broken dna. Nature, 535:566-, July 2016.

[87] Ciro Cecconi, Elizabeth A Shank, Frederick W Dahlquist, Susan Marqusee, and Carlos Bustamante. Protein-dna chimeras for single molecule mechanical folding studies with the optical tweezers. European biophysics journal: EBJ, 37(6):729-738, July 2008.

[88] Miklós S. Z. Kellermayer, Steven B. Smith, Henk L. Granzier, and Carlos Bustamante. Folding-unfolding transitions in single titin molecules characterized with laser tweezers. Science, 276(5315):1112-1116, 1997.

[89] Jeffrey T. Finer, Robert M. Simmons, and James A. Spudich. Single myosin molecule mechanics: piconewton forces and nanometre steps. Nature, 368(6467):113-119, 1994.

[90] A. Ashkin, J. M. Dziedzic, and T. Yamane. Optical trapping and manipulation of single cells using infrared laser beams. Nature, 330(6150):769-771, 1987.

[91] Hu Zhang and Kuo-Kang Liu. Optical tweezers for single cells. Journal of the Royal Society, Interface, 5(24):671-690, July 2008. 
[92] Niall McAlinden, David G Glass, Owain R Millington, and Amanda J Wright. Accurate position tracking of optically trapped live cells. Biomedical optics express, 5(4) :1026-1037, March 2014.

[93] Alex J. Crick, Michel Theron, Teresa Tiffert, Virgilio L. Lew, Pietro Cicuta, and Julian C. Rayner. Quantitation of malaria parasite-erythrocyte cell-cell interactions using optical tweezers. Biophysical Journal, 107(4):846-853, 2014.

[94] Jenny M. Tam, Carlos E. Castro, Robert J. W. Heath, Michael L. Cardenas, Ramnik J. Xavier, Matthew J. Lang, and Jatin M. Vyas. Control and manipulation of pathogens with an optical trap for live cell imaging of intercellular interactions. PLOS ONE, 5(12):1-10, 122011.

[95] Suddhashil Chattopadhyay, Radu Moldovan, Chuck Yeung, and X. L. Wu. Swimming efficiency of bacterium escherichiacoli. Proceedings of the National Academy of Sciences, 103(37):13712-13717, 2006.

[96] C. López-Quesada, A.-S. Fontaine, A. Farré, M. Joseph, J. Selva, G. Egea, M. D. Ludevid, E. Martín-Badosa, and M. Montes-Usategui. Artificially-induced organelles are optimal targets for optical trapping experiments in living cells. Biomed. Opt. Express, 5(7):1993-2008, Jul 2014.

[97] Satoru Ayano, Yuichi Wakamoto, Shinobu Yamashita, and Kenji Yasuda. Quantitative measurement of damage caused by 1064-nm wavelength optical trapping of escherichia coli cells using on-chip single cell cultivation system. Biochemical and Biophysical Research Communications, 350(3):678 - 684, 2006.

[98] Guenther Leitz, Erik Fällman, Simon Tuck, and Ove Axner. Stress response in caenorhabditis elegans caused by optical tweezers: wavelength, power, and time dependence. Biophysical journal, 82(11916877):2224-2231, April 2002.

[99] H. Liang, K. T. Vu, P. Krishnan, T. C. Trang, D. Shin, S. Kimel, and M. W. Berns. Wavelength dependence of cell cloning efficiency after optical trapping. Biophysical journal, 70(8785310):1529-1533, March 1996.

[100] Y. Liu, D. K. Cheng, G. J. Sonek, M. W. Berns, C. F. Chapman, and B. J. Tromberg. Evidence for localized cell heating induced by infrared optical tweezers. $B i$ ophysical journal, 68(7612858):2137-2144, May 1995.

[101] K. C. Neuman, E. H. Chadd, G. F. Liou, K. Bergman, and S. M. Block. Characterization of photodamage to escherichia coli in optical traps. Biophysical journal, 77(10545383):2856-2863, November 1999. 
[102] M. B. Rasmussen, L. B. Oddershede, and H. Siegumfeldt. Optical tweezers cause physiological damage to escherichia coli and listeria bacteria. Applied and environmental microbiology, 74(18310432):2441-2446, April 2008.

[103] Ming Dao, Chwee Teck Lim, and Subra Suresh. Mechanics of the human red blood cell deformed by optical tweezers. Journal of the Mechanics and Physics of Solids, 51(11-12):2259-2280, 2003.

[104] Hervé Turlier, Dmitry A Fedosov, Basile Audoly, Thorsten Auth, Nir S Gov, Cécile Sykes, J-F Joanny, Gerhard Gompper, and Timo Betz. Equilibrium physics breakdown reveals the active nature of red blood cell flickering. Nature Physics, $12(5): 513,2016$.

[105] Egy mikromanipulátor struktúrához tapasztott sejt 6 szabadsági fokú térbeli manipulációja. https://drive.google.com/file/d/10inLv9cqcsyGLv-xk83dU_ 23B4gX8gRz/view?usp=sharing.

[106] Keir C. Neuman and Steven M. Block. Optical trapping. The Review of scientific instruments, 75(16878180):2787-2809, September 2004.

[107] AntTweakBar GUI library. http://anttweakbar.sourceforge.net/doc/.

[108] Holographic optical tweezers, optical trapping of fluorescent microbeads. https: //www . youtube. com/watch?v=Dzkbyg7St5g.

[109] Benjamin Harke, Chaitanya K. Ullal, Jan Keller, and Stefan W. Hell. Threedimensional nanoscopy of colloidal crystals. Nano Lett., 8(5):1309-1313, May 2008.

[110] Stefan Hell and Ernst HK Stelzer. Fundamental improvement of resolution with a 4pi-confocal fluorescence microscope using two-photon excitation. Optics Communications, 93(5-6):277-282, 1992.

[111] P.J. Shaw, D.A. Agard, Y. Hiraoka, and J.W. Sedat. Tilted view reconstruction in optical microscopy. three-dimensional reconstruction of drosophila melanogaster embryo nuclei. Biophysical Journal, 55(1):101 - 110, 1989.

[112] Jan Huisken, Jim Swoger, Filippo Del Bene, Joachim Wittbrodt, and Ernst H. K. Stelzer. Optical sectioning deep inside live embryos by selective plane illumination microscopy. Science, 305(5686):1007-1009, 2004.

[113] Uros Krzic, Stefan Gunther, Timothy E. Saunders, Sebastian J. Streichan, and Lars Hufnagel. Multiview light-sheet microscope for rapid in toto imaging. Nature Methods, 9:730, June 2012. 
[114] Jim Swoger, Jan Huisken, and Ernst H. K. Stelzer. Multiple imaging axis microscopy improves resolution for thick-sample applications. Opt. Lett., 28(18):1654-1656, Sep 2003.

[115] Jim Swoger, Peter Verveer, Klaus Greger, Jan Huisken, and Ernst H.K. Stelzer. Multi-view image fusion improves resolution in three-dimensional microscopy. Opt. Express, 15(13):8029-8042, Jun 2007.

[116] Phase correlation. https://en.wikipedia.org/wiki/Phase_correlation.

[117] Egy mitokondrium festett sejt három dekonvolvált képsorozata és a fuzionált eredmény maximum intenzitás projekciói. Ajánlott letöltve megtekinteni! https: //drive.google. com/open?id=1G8eu3CVLWeD5dro72MHbsld6BoQKqs0D. 